\title{
HANS VIERTLER
}

BIBLIOTECA

Instituto do Química

Universidade de São Paulo

8255

\section{ESPECTROSCOPIA NO ULTRAVIOLETA DE CICLOALCANONAS $\alpha$-ALQUILTIO. \\ SUBSTITUIDDAS}

Tese de Livre Docência — Instituto de Química

Universidade de São Paulo 
Companion, comforter and guide and friend,

As much as love asks love, does thought ask thought. 


\section{A GR ADECIMENTOS}

A todos aqueles que de alguma forma quer com sua colaboração direta, quer com sua amizade e apoio, contribuíram pa ra que esta tese se tornasse possĩvel.

Em particular agradeço:

A Profa.Dra. Blanka Wladislaw pelas valiosas discussões e constante estîmulo.

As Profa.Dra. Vera Lūcia Pardini, Sra. Elisa Demant e Srta. Heloísa D.Cajon pela efetiva participação no desenvolvi mento do presente trabalho.

Aos Profs.Drs. Robert Rittner, Paulo R.01ivato e Josē A.Vanin pela execução e discussão de alguns espectros de ressonância magnētica nuclear e infravermelho.

A Sra. Isabel C.C.Calegão pela doação de algumas de suas amostras.

A Dra. Liliana Marzorati pelo cuidado com que reviu o manuscrito e pelas criticas construtivas.

A Sra. Neyde Barranjard pelo zelo e dedicação na datilografia. 


\section{INDICE}

Pag.

Capitulo I - 0 GRUPO CARBONILA E A TRANSIÇÃO ELETRONICA $n \rightarrow \pi^{*}$

1.1. Introdução.

1.2. Interações intramoleculares e seus efeitos sobre as transições eletrônicas do grupo carbonila. . . .

1.2.1. Interações entre o grupo carbonila e outros grupos funcionais............

1.2.2. Interações entre o ātomo de enxofre e o gru po carbonila.

Capitulo II - RESULTAdOS E DISCUSSÃO. . . . . . . . . 24

2.1. Introdução............... . . . . . 24

2.2. Resultados................. . . . . 25

2.3. Discussão. . . . . . . . . . . . . . 47

Capitulo III - PARTE EXPERIMENTAL . . . . . . . . . . 63

3.1. Instrumentos, medidas espectroscōpicas e anālises. 63

3.2. Compostos. . . . . . . . . . . . . . 64

3.2.1. Solventes.............. 64

3.2.2. Compostos disponīveis em nosso laboratōrio. 64

3.2.3. Compostos sintetizados......... . 65

3.2.3.1. 2-Etiltiociclohexanona (XXX) . . 65

3.2.3.2. 2-t-Butiltiobutilciclohexanona $(X X X I)$. . . . . . . . . 66

3.2.3.3. 2-Etiltio-2-metilciclohexanona (XXXII). . . . . . . . . 68

3.2.3.4. 2-Etiltio-4-t-butilciclohexanona

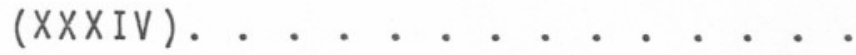


3.2.3.5. Octahidro-4a-meti 1-3-etiltio-2(1H)-

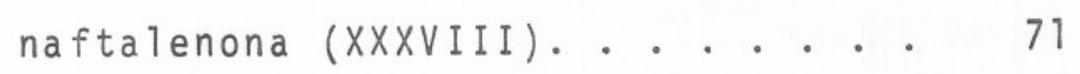

3.2.3.6. Reações de sulfenilação de cetonas . 74

3.2.3.7. 2-Metiltiociclohexanona (XXIX) . . 75

3.2.3.8. 2-Metiltio-4-t-butilciclohexanona

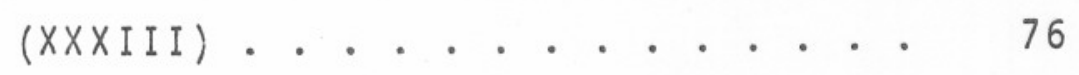

3.2.3.9. Octahidro-4a-meti1-3-metiltio-2(1H)naftalenona $(X X X V I I) \cdot . \cdot . \cdot . \cdot 76$

3.2.3.10. 3-Metiltio-1,7,7-trimetilbiciclo-

$$
[2.2 .1] \text { heptanona-2 (XLII) . . . } 77
$$

SUMARIO . . . . . . . . . . . . . . . . . . . . . . 79

SUMMARY . . . . . . . . . . . . . . . . . . 80

REFERENCIAS BIBLIOGRAFICAS. . . . . . . . . . . . . . . . 81 


\section{GRUPO CARBONILA E A TRANSIÇÃO ELETRÕNICA $\mathrm{n} \rightarrow \pi^{*}$}

\subsection{INTRODUÇÃO}

As molēculas que contēm oxigênio em um grupo insaturado, geralmente mostram, nos espectros eletrōnicos, bandas de absorção de intensidade reduzida $\left(\varepsilon=10\right.$ a 100). Burawoy ${ }^{1}$ as de nominou bandas - $R$, pois imaginava que eram associadas a um estado excitado biradicalar. Como a existência destas bandas é devida a transições de elētrons não-ligantes a orbitais $\pi$ antiligantes ${ }^{2}$, Kasha ${ }^{3}$ as chamou de $n \rightarrow \pi^{*}$ ou então, bandas $n-\pi$. Aldeỉdos e cetonas. alifáticas apresentam uma banda de absorção $n \longrightarrow \pi^{*}$ fraca na região de $290 \mathrm{~nm}(\varepsilon=15)$ e foi pelo estudo detalhado do formałdeído ${ }^{4,5 a}$ que as propriedades caract $\underline{\underline{\epsilon}}$ rísticas desta banda foram estabelecidas. Esta transição, no for maldeido, é proibida por simetria, pois o produto de um orbital $p_{x}$ e um $p_{y}$ não possui momento dipolar. A intensidade das bandas $n \rightarrow \pi^{*}$ depende somente da simetria local do orbital não-ligante. Assim, no caso do acetaldeĩdo, a transição em questão seria per mitida considerando a simetria total da molēcula, porēm, a banda ē de baixa intensidade devido à simetria local da ligação $C=0$.

Alēm da banda de absorção $n \rightarrow \pi^{*}$ de baixa intensidade, o acetaldeĩdo e a acetona mostram duas regiōes de absorções intensas, entre 100 e $200 \mathrm{~nm}^{6}$. As bandas em comprimentos de onda maiores foram atribuĩdas por McMurry ${ }^{2}$ a transições $n \rightarrow \sigma^{*}$, porēm, uma outra possibilidade seria uma transição $\sigma \rightarrow \pi^{*}{ }^{4}$,pois ambas seriam transições permitidas. As de comprimento de onda menor, em $170 \mathrm{~nm}$, corresponderiam a uma transição $\pi \rightarrow \pi^{*}{ }^{2}$. 
A posição da banda $n \rightarrow \pi$ da acetona e de outros com postos carbonilicos depende da natureza do solvente e, no caso da acetona, nota-se um deslocamento hipsocrômico ou deslocamento para o azul, indo de solventes apolares a polares ${ }^{4}$. Esta pro priedade é, geralmente, observada com as bandas $n \rightarrow \pi *$ e foi con siderada como a maior evidência do carāter das transições eletrōnicas responsāveis pelas mesmas.

Um estudo de Bayliss e Johnson ${ }^{7 a}$ de efeitos de solventes sobre as intensidades das bandas $n \longrightarrow \pi^{*}$ de vārias cetonas alifáticas acíclicas e da ciclohexanona mostrou não existir uma solução simples para o problema. A intensidade da transição $n \rightarrow \pi^{*}$ do grupo carbonila, no estado gasoso, è considerada como resultante do empréstimo de intensidade de transições permiti das de maior energia, devido a uma perturbação vibracional. Os autores consideram a chave para o problema das intensidades, em solução, a maneira pela qual as perturbações causadas pelas moléculas de solventes afetariam este empréstimo de intensidade. cálculos efetuados pelos mesmos pesquisadores ${ }^{7 b}$ resultaram em in tensificações das bandas, cuja concordância com os dados experi mentais era satisfatōria.

A causa do pronunciado efeito de solvente parece estar intimamente ligada à grande mudança de distribuição eletrónica quando a molécula é excitada. O deslocamento hipsocrómico da banda $n \rightarrow \pi^{*} \bar{e}$ particularmente importante quando um hidrocar boneto é substituīdo por um solvente hidroxỉlico. No estado fun damental, a formação de ponte de hidrogênio com o par solitārio de elētrons não-ligantes è muito mais importante do que no estạ do excitado, onde um dos elétrons é removido do orbital $n$ e pro movido a um orbital $\pi$ * anti-ligante.

McCone $11^{8}$ e Pimente $1^{9}$ apontaram que o princípio de 
Franck-Condon era um fator importante no efeito do solvente nas transições $n \rightarrow \pi^{*}$. Assim, o mäximo da banda de absorção seria dẹ terminado pela configuração particular das molēculas de solvente, favorecida no estado fundamental. Nos espectros de emissão a solvatação que confere a maior estabilidade ao estado excitado, seria responsāvel pela posição do máximo da banda. Desta ma neira, enquanto um deslocamento para o azul de $15 \mathrm{~nm}$ è observado no espectro de absorção da acetona, substituindo hexano por àgua, a posição da banda de fluorescēncia em $300 \mathrm{~nm}$ não ē afetạ $\operatorname{tada}{ }^{4}$.

0 efeito de solventes, entretanto, deve ser interpre tado com cautela, pois vārios fatores como as conformações mole culares, podem afetar sensivelmente a solvataçãoloa,b.

A intensidade $(\varepsilon)$ da banda $n \rightarrow \pi^{*}$ do grupo carbonila normalmente é da ordem de 20 , porém, compostos carbonīlicos subs tituỉdos em diferentes posições, relativamente ao grupo carbon la, mostraram uma intensificação da transição $n \rightarrow \pi^{*}$ em relação aos anālogos não substituỉdos, apesar da não ocorrência de inte ração direta entre os substituintes e o grupo carbonila. Uma di $\underline{s}$ cussão dos fatores responsāveis por tais observações, bem como uma exaustiva revisão bibliogrāfica, foram apresentadas por Tru fem $^{11}$.

A transição $n \rightarrow \pi^{*}$ normal do grupo carbonila è proibida para a absorção de dipolo elētrico, porēm ē permitida para a de dipolo magnētico. Quando a primeira se torna permitida, têm-se as condições para a rotação óptica ${ }^{12}$. A força rotacional $\left(R_{K}\right)^{13 a}$ pode ser escrita como produto escalar:

$$
R_{K}=\mu \frac{K}{e} \cdot \mu \frac{K}{m}
$$


onde $\mu \stackrel{K}{e}$ e $\mu_{m}^{K}$ possuem as dimensões de um momento dipolar ele trico e de um magnētico, respectivamente. Quando uma molécula possui um centro de simetria ou um plano de simetria, o produto da relação (1) será igual a zero e a molécula serä opticamente inativa. Os elētrons envolvidos nas transições de cetonas saturadas estão localizados, essencialmente, no grupo carbonila que possui dois planos de simetria e, portanto, em primeira aproximação, as regras de simetria acima referidas aplicar-se-iam ao cromōforo, como se fosse a molēcula inteira. Qualquer atividade ōptica, associada com as transições do cromóforo, apareceria em virtude de uma perturbação não-simētrica dos elētrons enṿolvidos nas transições, por uma vizinhança assimëtrica ou quiral. Moffitt et az. 14 baseados nestes principios de simetria, deduzi ram uma simples regra de octantes ${ }^{13 b}$, que relaciona o sinal e a amplitude do efeito Cotton, exibido por cetonas saturadas, e a disposição dos átomos no espaço ao redor do grupo carbonila das cetonas. Desde aquela ēpoca, a regra dos octantes tem sido obje to de estudos tanto experimentais como teöricos ${ }^{15}$.

\subsection{INTERAÇOES INTRAMOLECULARES E SEUS EFEITOS SOBRE AS TRANSI ÇÕES ELETRŌNICAS DO GRUPO CARBONILA}

As interações intramoleculares serão discutidas em duas partes: a primeira (1.2.1.) envolvendo o grupo carbonila e quaisquer àtomos ou grupos substituintes, com exceção do àtomo de enxofre, que será objeto de discussão da segunda parte (1.2.2.).

1.2.1. Interações entre o grupo carbonila e outros grupos funcionais

Um àtomo de halogênio, na posição a em relação aogrụ po carbonila, em cetonas aciclicas, como a cloroacetona, não 
apresenta um efeito sensĩvel sobre a transição $n \rightarrow \pi^{*}$ do grupo carbonila. Em cetonas cỉclicas $\alpha$-halogenosubstituidas, no entan to, esta transição mostrou ser influenciada pela estereoquímica dos compostos envolvidos $5 b$. Cookson ${ }^{16}$ e Leonard e Owens ${ }^{17}$, estú dando $\alpha$-halogenocicloalcanonas, observaram que, quando cloro ou bromo eram equatoriais, havia pequenos deslocamentos hipsocrôm $\cos (\sim 5 \mathrm{~nm}$ ) e reduzida ou nenhuma intensificação das bandas de absorção $n \rightarrow \pi^{*}$ em relação às cetonas anālogas não substituĩdas. Átomos de cloro ou bromo axiais, entretanto, produziam deslocamentos batocrōmicos de 10 e 20 a $30 \mathrm{~nm}$, respectivamente, acompa nhados de uma pronunciadå intensificação das bandas.

Allinger e col. 18 estudaram teoricamente as transições $n \rightarrow \pi^{*}$ de $\alpha$-halogenocicloohexanonas e concluiram que a inte ração entre um orbital $\pi^{*}$ do grupo carbonila $(C=0)$ e um orbital $\sigma *$ da ligação carbono-halogênio $(C-X)$, de energia relativamente baixa quando o halogênio era axial, seria responsävel pelo deslocamento batocrômico observado. A fig. 1 mostra o diagrama de interação proposto, podendo ser considerado como uma interação hiperconjugativa entre os orbitais $\pi^{*}{ }_{C=0}$ e $\sigma^{*}{ }_{C-X}$.
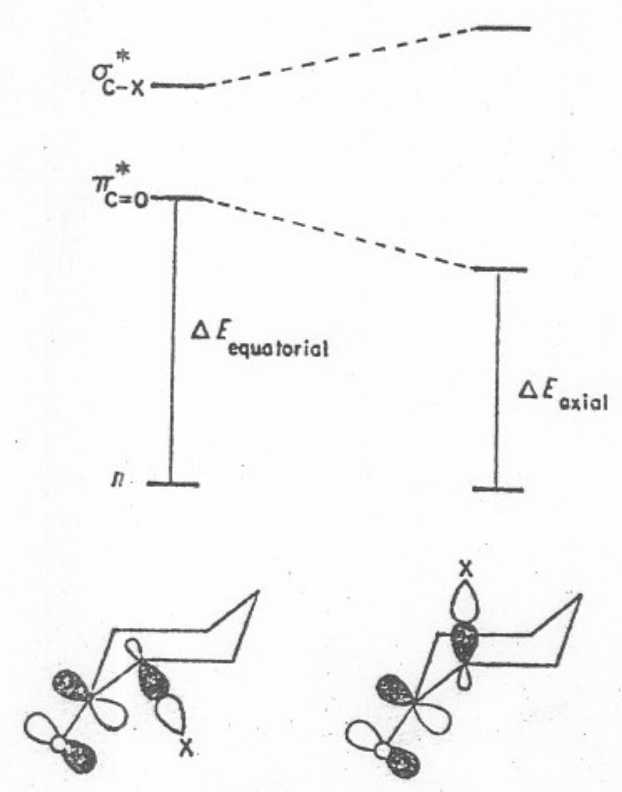

Figura 1 
Labhart e Wagniẻre ${ }^{19}$ verificaram que a intensificação da transição $n \rightarrow \pi^{*}$ não era a única característica das cetọ nas ciclicas $\beta, \gamma$-insaturadas (I, II). Os espectros no ultravioleta destes compostos mostravam uma outra banda em aproximadamente $210 \mathrm{~nm}$ e os autores sugeriram que ela corresponderia a um

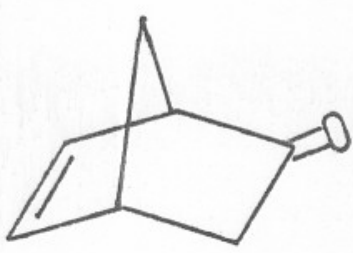

I

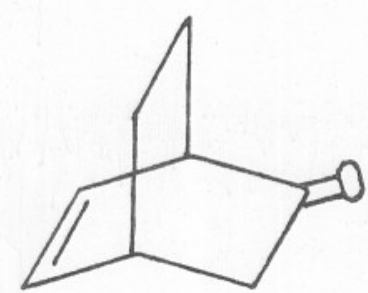

I I

estado de transferēncia de carga, tambēm responsāvel pela inten sificação da transição $n \longrightarrow \pi^{*}$. Murre $11^{4}$, partindo do ponto de vista que dois estados interagem apenas quando hā participação ou do mesmo orbital doador ou do mesmo orbital aceptor, examinou a possibilidade de dois estados de transferēncia de carga interagirem com o estado $n \rightarrow \pi^{*}\left(\psi_{n}^{c}\right)$ (fig. 2$)$.
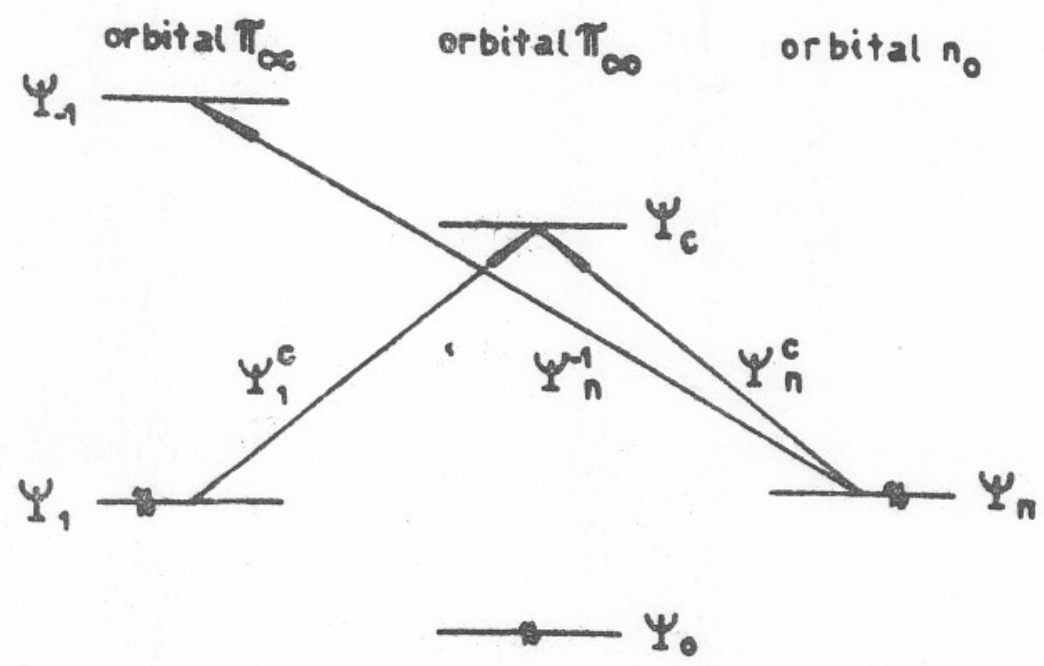
Os cālculos mostraram que o entrosamento entre $\psi_{-1}$ e $\psi_{c}$ era maior do que entre $\psi_{1}$ e $\psi_{n}$, portanto, a banda correspondente ao estado $\psi_{1}^{c}$ deveria ser mais intensa do que aquela correspondente ao estado $\psi_{n}^{-1}$. Consequentemente, o autor achou mais provāvel ser 0 estado de transferência de carga $\psi_{1}^{c}$ o responsävel pelo aumento de intensidade da transição $n \rightarrow \pi^{*}\left(\psi_{n}^{c}\right)$. Este mesmo estado de transferēncia de carga seria responsāvel pela banda em cerca de $210 \mathrm{~nm}$.

Cookson e col. 20 estudaram cetonas $\gamma, \delta$-insaturadas e B-aminosubstituidas, nas quais havia dois orbitais $p$ separados por três ligações $\sigma$. Verificaram que estes compostos apresentavam uma banda de transferência de carga na região do ultraviole ta. A transição responsāvel por esta banda foi denominada de sigma acoplada pois a sua existência foi explicada pela interação entre os dois orbitais $p$ atravēs das ligações o que os se paravam. Hudec 21 examinou empiricamente as propriedades espectroscōpicas (espectros no ultravioleta, dicroismo circulare dis persão ōptica rotatōria) de $\alpha$-e $\beta$-aminociclohexanonas atravēs da anālise conformacional e concluiu que existiam dois caminhos pelos quais dois grupos funcionais podiam interagir atravës das ligações $\sigma$. As conclusões desta anālise foram reunidas em oito regras, das quais quatro são de interesse nos espectros no ultravioleta:

(i) Uma parte do deslocamento batocrômico em transições $n \rightarrow \pi^{*}$ serā resultante do acoplamento dos nỉveis de energia $\pi / \pi$ * do grupo carbonila $C=0$ e $\sigma / \sigma^{*}$ das ligações $C-N$, quando estes podem interagir, posição axial para as $\alpha$ - (III) e equatorial para as B-aminocetonas (IV) (arranjo W). 


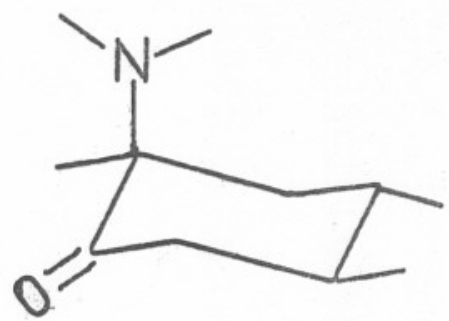

I I I

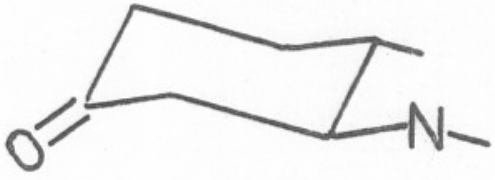

IV

(ii) A outra parte do deslocamento batocrōmico em transições $n \rightarrow \pi^{*}$ resultará quando o par solitārio de elétrons, no nitrogênio, for trans-diaxial em relação à ligação $C_{\alpha^{-}}-C=0$ com o $N$ ligado ao carbono a (V) ou trans-diaxial em relaçãoà li gação $C_{\alpha}-C_{\beta} \operatorname{com} 0 N$ no carbono $\beta$ (VI).

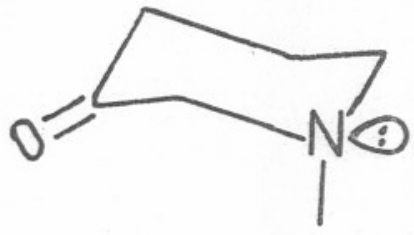

v

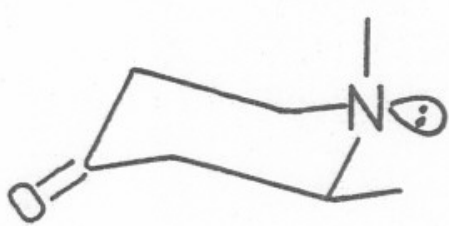

V I

(iii) Quando a condição (ii) for satisfeita, a probạ bilidade da transição $n \rightarrow \pi^{*}$ serā aumentada $(\varepsilon \approx 50-80)$ e uma nova banda aparecerá em comprimento de onda menor, descrita como uma transição sigma acoplada ${ }^{20}$. Uma alternativa para a descrição desta banda seria um desdobramento da transição $\pi \longrightarrow \pi$ * pelo acoplamento com o par solitārio do nitrogênio, sendo o com ponente de menor energia deslocado para $220-240 \mathrm{~nm}$.

(iv) Quando o par solitārio do ātomo de $N$ em $\alpha$ for cis à ligação $C_{\alpha}-C=0$ (VII) ou cis à ligação $C_{\alpha}-C_{\beta}$ (VIII) em uma $\beta$-aminocetona, a probabilidade da transição $n \rightarrow \pi$ * não será 
aumentada. Aplica-se a mesma conclusão quando a ligação $C-N$ no carbono $\beta$ for axial (IX).

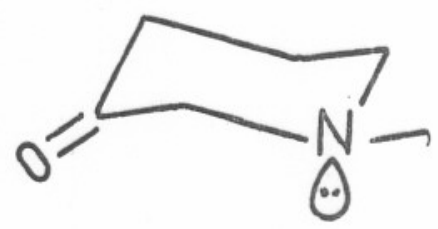

V I I

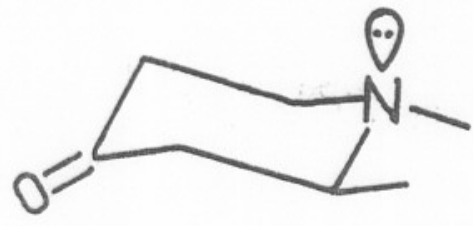

V I I I

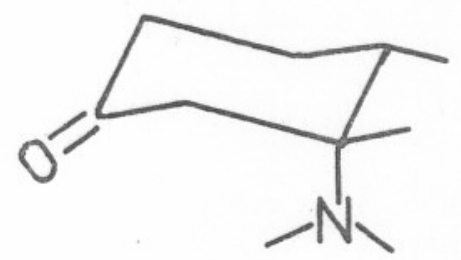

IX

As conclusões empïricas estão de acordo com um trata mento teōrico da interação de orbitais atravēs das ligações ${ }^{22}$; en tretanto, outros fatores têm importância nestas interações, tais como as energias relativas dos orbitais $\pi$ e $\pi^{*}$ do grupo carbon $\underline{i}$ la, $\sigma$ e $\sigma^{*}$ da ligação carbono-nitrogênio e $n$ do nitrogênio. No caso do nitrogênio ser substituỉdo por oxigênio ou enxofre, a si metria dos substituintes destes ātomos, provavelmente, deveria influir sobre as interações.

Levin et az. ${ }^{23}$ estudaram teoricamente as interações existentes nos aceitaldeỉdo e acetona $\alpha$-aminosubstituídos. Consideraram três graus de liberdade nos cālculos efetuados:

1 - Torção descrita pelo ângulo $\emptyset(X a)$ que correspon de à rotação em torno da ligação $C(1)-C(2)$ e è igual a zero quando a ligação $C(2)-N$ eclipsa com a ligação $C(1)-0$.

2 - Torção em torno da ligação $C(2)$ - N, descrita pe10 ângulo $\theta$ (Xb) que $\bar{e}$ igual a zero quando o orbital $n$ do nitro 


$$
\begin{aligned}
& \text { gênio eclipsa com a ligação } C(1)-C(2) \text {. } \\
& 3 \text { - Angulo da ligação } C-C-N
\end{aligned}
$$

A fig. 3 mostra as projeções de Newman (A) que ilustram as definições de $\theta$ e $\phi$ e de algumas conformações importantes nos cálculos (B).

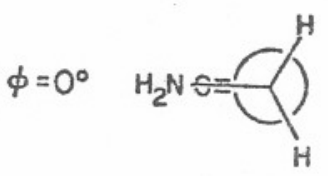

$\phi=90^{\circ}$

$\phi=180^{\circ}$
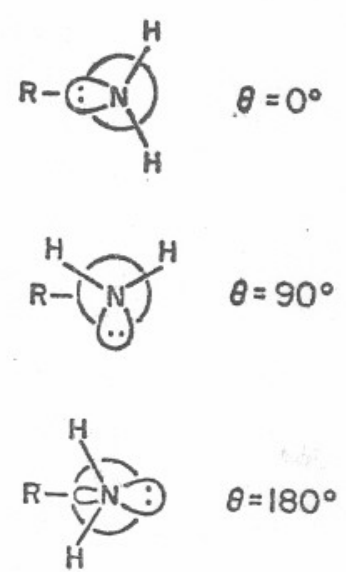

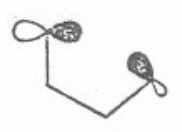

$(0,0)$

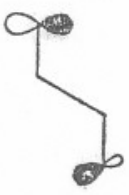

$(180,0)$

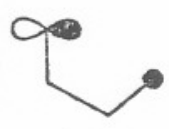

$(0,90)$

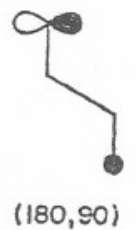

B

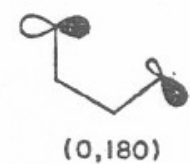

$(0,180)$

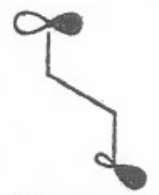

$(180,180)$

Figura 3

Cinco interações bāsicas foram consideradas na deter minação da energia dos orbitais importantes - os dos dois pares solitārios de elētrons e dos orbitais $\pi$ e $\pi^{*}$ do grupo carbonila: (a) uma interação atravēs do espaço dos pares solitārios do oxigênio e nitrogênio; (b) uma interação atravēs das ligações em que estão envolvidos os pares solitārios e a ligação $\sigma C(1)-C(2)$; (c) uma hiperconjugação entre a ligação $C-N$ e o sistema $\pi$ do grụ po carbonila; (d) uma interação direta entre o par solitārio de elētrons do nitrogênio com o sistema $\pi$ do grupo carbonila; (e) uma ponte de hidrogênio entre o par solitārio de elētrons do $C=0$ 
e os hidrogênios do amino-grupo.

Dois tipos de cālculos foram efetuados diferindo ape nas pelo nível de sofisticação, porēm, os resultados obtidos con cordaram razoavelmente. Em cada caso, os dois orbitais ocupados de maior energia, são combinações dos orbitais dos pares solitā rios ( $n_{s}$ : simētrico e $n_{a}$ : anti-simētrico) sendo o simëtrico $\left(n_{s}\right)$ de maior energia. O desdobramento dos nīveis energēticos dos pares solitārios é função de interações atravēs do espaço e das ligações, com a segunda predominando. A interação atravēs do espaço mostrou-se mais importante para $\phi=0$ e $\theta=0$ ou $180^{\circ}$, enquanto que o acoplamento atravēs das ligações seria māximo pa ra os conförmeros $(\phi, \theta=0)$ e $\left(\phi, \theta=180^{\circ}\right)$.

0 espectro no ultravioleta da 1-azabiciclo $[3.3 .1]$ nonanona-3 (XI) foi examinado à luz dos resultados dos cālculos. 0 ângulo $\phi$ teria um valor entre 150 e $180^{\circ}$ e o ângulo $\theta$ prōximo

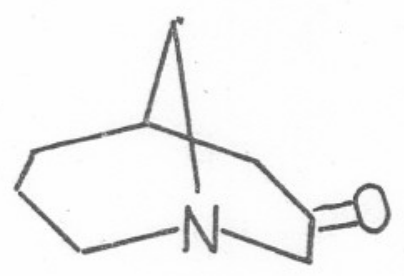

$X I$

a $180^{\circ}$. A transição de comprimento de onda maior em (XI) apresentava um deslocamento batocrômico com o decrēscimo da polarida de do solvente, o que estaria de acordo com uma transição $n \rightarrow \pi^{*^{4}}$ e envolveria a promoção de um elētron do nỉvel $n_{s}$. A segunda transição eletrônica, em $235 \mathrm{~nm}$, foi considerada como sendo a ex citação de um elētron do nỉvel $n_{a}$ e alguns aspectos do espectro sustentavam tal hipōtese. Os autores concluiram que as propriedades espectrais eram extremamente sensiveis em relação ao grau 
de liberdade $\theta$. A mesma dependência de $\theta$ foi observada quando a força rotacional da transição $n_{s} \rightarrow \pi^{*}$ foi calculada e pequenas variações de $\theta$ podiam alterar tanto o sinal como a magnitude da quela.

Uma manifestação experimental $7^{23}$ da interação dos pares solitārios de elētrons atravēs das ligações foi observada em dados da espectroscopia fotoeletrônica na sērie de (XII) a (XIV). Encontrou-se uma diferença nos potenciais de ionização de 1,03 eV entre os pares solitārios de (XII) e (XIII), porēm, esta diferença aumentou para 1,59 eV em (XIV) devido à interação atravēs das ligações. Um fato inesperado, no entanto, foi o de o potencial de ionização em (XIV, 8,24 eV) ser maior do que aquele observado em (XIII, 8,02 eV).

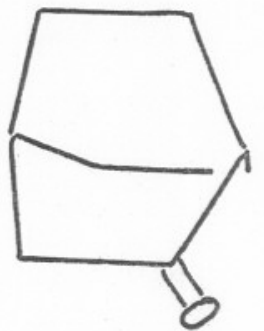

(XII) $9.05 \mathrm{eV}$

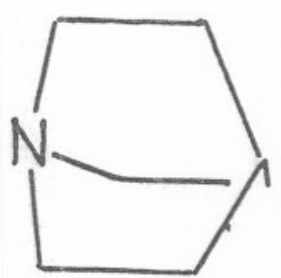

(XIII) $8.02 \mathrm{eV}$

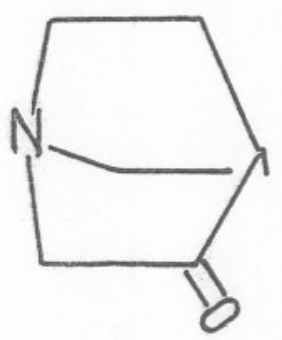

(XIV) $8.24 \mathrm{eV} \quad 9.83 \mathrm{eV}$

Com o objetivo de obter maiores esclarecimentos acer ca das transições sigma acopladas, Verhoeven e col. ${ }^{24}$ verificaram que o espectro no ultravioleta da aminocetona (XV) apresentava uma banda de absorção em $243 \mathrm{~nm}$ (n-hexano, $\varepsilon=1366$ ) inexis tente nos anālogos não substituīdos. Os autores sugeriram que esta transição possuia a natureza de transferência de carga, en volvendo a excitação de um elētron do par solitārio do nitrogènio a um orbital $\pi^{*}$ do grupo carbonila. A transição em questão parecia emprestar a maior parte de sua intensidade da transição $\pi \rightarrow \pi *$ do $C=0$, o que implicaria em uma interação dos orbitais 
do grupo carbonila e do par solitārio do nitrogênio. Consideran do a transição $n \rightarrow \pi^{*}$ de $(X V)$, esta interação ocorreria, princ $\underline{i}$ palmente, entre o par solitārio e o nível $\pi$ ocupado mais elevado e esta hipōtese parecia ser sustentada pela transferência de carga relativamente pequena no estado fundamental.

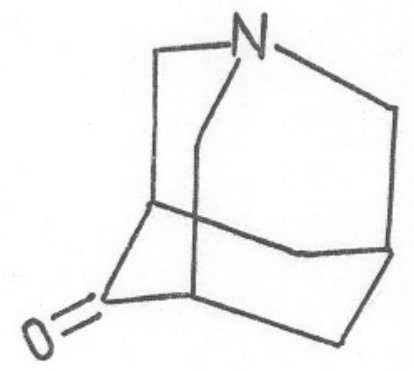

$X V$

0 espectro fotoeletrônico 25 , entretanto, mostrou que os potenciais de ionização para o par solitārio do nitrogènio em (XV) era de 8,21 eV e para o 1-aza-adamantano, o anālogo não substituido, era de $7,94 \mathrm{eV}$. Os autores explicaram esta diferen ça como resultante do efeito indutivo do grupo carbonila sobre o nitrogēnio e excluiram a interação atravēs das ligações com o orbital $\pi$ do grupo carbonila, cujos potenciais de ionização em (XV) ena adamantanona, o anālogo não substituỉdo, eram de 8,81 e $8,80 \mathrm{eV}$, respectivamente.

Ernstbrunner e Hudec ${ }^{26}$ relataram as mudanças relativas nas energias das transições $n \rightarrow \pi^{*}$ em uma sērie de cetonas substituidas por fluor e iodo. Os deslocamentos batocrōmico ou hipsocrōmico observados dependiam do nūmero de ligações $C-C$ entre o grupo carbonila e os substituintes em posições nas quais as interações eram possîveis (ver ref. $21, \mathrm{päg} .7$ ). Assim, as ce tonas $\alpha$ - e $\gamma$-fluorosubstituỉdas mostraram deslocamentos batocrō micos relativos maiores do que as correspondentes substituídas 
por iodo, enquanto que deslocamentos hipsocrōmicos eram observa dos nas $\beta-$ e $\delta$-substituídas. As cloro e bromo cetonas apresenta ram um comportamento intermediārio. Dois fatores foram avocados para explicar estas observações: (a) o efeito indutivo de um substituinte não se manifestaria por um decrēscimo uniforme da densidade eletrônica, mas atravēs de uma alternação de cargas ao longo da cadeia carbônica; (b) a dependência das perturbações causadas pelos substituintes das conformações moleculares. Devido ao fator (a) resultaria uma estabilização ou desestabil $\underline{i}$ zação dos orbitais $n$ do oxigênio carbonílico. 0 efeito do desilo camento o poderia ser modificado ou mesmo alterado em sentido pela retrodoação $\pi$ do substituinte e, segundo os autores, o efe to global seria responsāvel pela mudança da energia de transição. Em cetonas $\alpha$ - e $\gamma$-substituỉdas, o efeito do deslocamento $\sigma$ controlaria, principalmente, os niveis $\pi / \pi^{*}$, enquanto que 0 nível $n$ seria controlado pela retrodoação $\pi$. Efeitos opostos seriam observados nas cetonas $\beta$ - e $\delta$-substituidas. Estas conclusões foram baseadas no fator (b).

Hudec $^{27}$ a fim de avaliar o efeito do par solitāriode elētrons do nitrogênio, um doador $\pi$, sobre as transições $n \rightarrow \pi^{*}$, estudou as propriedades espectroscópicas de cetonas axial- e equatorialmente substituídas na posição $\beta$ pelo grupo trimetiles tanila $\left(\operatorname{Me}_{3} S n\right)$, um doador $\sigma^{28}$. Os resultados observados permit $\underline{j}$ ram estabelecer uma analogia entre a ligação C-Sn, doadora $\sigma$ e - par solitārio do nitrogênio doador $\pi$, quando adequadamente or entados nas moléculas.

Em 1976, Verhoeven e col. ${ }^{29}$ analisaram, atravēs da espectroscopia noultravioleta, cetonas com $\beta$ - e $\gamma$-substituintes com pares solitārios facilmente ionizāveis ou elétrons $\pi$ e concluiram que,se a geometria das molēculas favorecia uma interação en 
tre o grupo carbonila e um substituinte, transições sigma acopladas eram observadas. Como a transição $\pi \rightarrow \pi^{*}$ em compostos car bonilicos ocorre em frequências muito maiores, os autores sugeriram que as intensidades das transições sigma acopladas eram devidas a outras configurações localmente excitadas, por exemplo, dos substituintes das cetonas.

\subsubsection{Interações entre o ātomo de enxofre e o grupo carbonila}

Em 1949, Fehnel e Carmack ${ }^{30}$ observaram que cetonas, contendo um grupo alquiltio ligado ao carbono a em relação ao grupo carbonila, apresentavam espectros no ultravioleta diferen tes daqueles dos compostos anālogos não substituīdos. Assim, en quanto os sulfetos absorviam em $210 \mathrm{~nm}(\varepsilon=1000$ - 1800) e as ce tonas na região de 275 a $295 \mathrm{~nm}(\varepsilon=15-30)$, os cetosulfetos es tudados pelos autores absorviam nas regiões de 295 a $300 \mathrm{~nm}$ $(\varepsilon=300)$ e de 240 a $245 \mathrm{~nm}(\varepsilon=400)$. Para explicar estes espectros anômalos, foram sugeridos dois tipos de interação: a hiper conjugação e uma interação eletrônica direta entre o ātomo de en xofre e o grupo carbonila.

Leonard e col. 31 observaram que o espectro no ultravioleta da 5-tiaciclooctanona (XVI) apresentava uma banda de a $\underline{b}$ sorção em $237 \mathrm{~nm}$, ausente nas cetona e sulfeto anālogos não subs tituỉdos. Um estudo da influência de solvente nesta banda mostrou um deslocamento batocrómico ao passar de solventes apolares para polares. Baseando-se neste fato e considerando a eleva da intensidade desta transição $(\varepsilon=2600)$, os autores concluiram ser o estado excitado mais polarizado que o fundamental. 


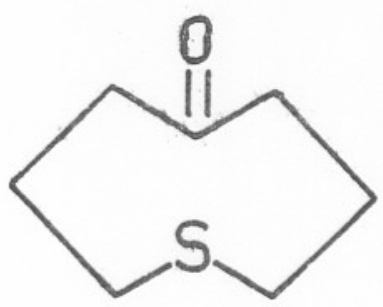

$X V I$

Bergson e Delin ${ }^{32}$ efetuaram um estudo das interaçōes nos estados fundamental e excitado da 4-tiahexanona-2 (XVII) pe los métodos da espectroscopia no infravermelho e no ultravioleta.

$$
\mathrm{CH}_{3} \mathrm{CH}_{2} \mathrm{SCH}_{2} \mathrm{COCH}_{3}
$$

A diminuição da frequência de estiramento da carbonila neste com posto, em comparação com o não substituỉdo, foi atribuỉda a uma redução da constante de força da carbonila. Os autores, baseados em um estudo da influência de solventes sobre a transição $\mathrm{n} \rightarrow \pi^{*}$ em aproximadamente $300 \mathrm{~nm}$, concluiram que o estado funda mental da molécula era mais polar do que o seu estado excitado. Esta conclusão era contrāria ã de Leonard e col. ${ }^{31}$, o que mostrava a importância das posições relativas do ätomo de enxofre e do grupo carbonila.

Paquette e Wise 33 , em 1967, sugeriram que a tiacetona (XVI) estudada por Leonard e col. ${ }^{31}$, devido a sua mobilidade conformacional, não permitia relacionar a interação heteroātomo-carbonila com a distância interatômica entre os centros envolvidos. Sintetizaram duas tetrahidro-1,4-tiapironas (XVIIIa,b) com o anel de seis membros da tiacetona em conformação barco rí gida. 


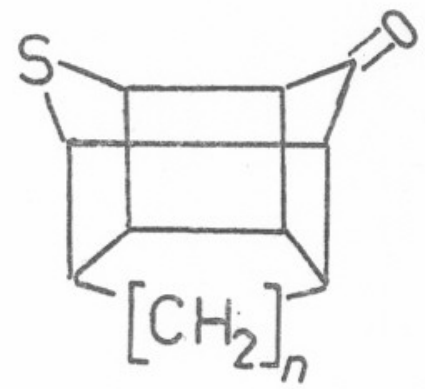

(a) $n=1 ;$ (b) $n=2$

XV I I I

Apesar da interação transanular no estado fundamental não ficar bem caracterizada, o espectro no ultravioleta mos trou uma banda de absorção em aproximadamente $240 \mathrm{~nm}$. Com base no estudo do deslocamento batocrômico desta banda com o aumento da polaridade do solvents, os autores a atribuiram a uma transferência de carga do enxofre ao grupo carbonila. Um fato digno de nota são as diferenças entre as intensidades das bandas observadas na cetona (XVI) $(\varepsilon=2600)$ e aquelas dos compostos $(X V I I I a)(\varepsilon=170-230)$ e (XVIIIb) $(\varepsilon=290-450)$. Paquette e Wise sugeriram que estas diferenças poderiam ser atribuĩdas a uma dependência da geometria da interação entre os orbitais $S-C_{C O}$, pois a maior mobilidade conformacional de (XVI) permiti ria uma interação orbital mais favorāvel.

Um estudo polarogräfico efetuado por Herzschuh e Borsdorf ${ }^{34}$ com 3-, 4- e 5-tiacicloalcanonas (XVI, XIX - XXIII) mostrou que as reduções eram consideravelmente mais fäceis do que as das cetonas anālogas sem enxofre. 


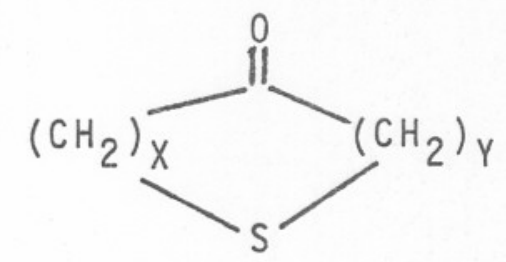

$$
\begin{array}{ll}
X=1, & Y=2(X I X) ; X=1, Y=3(X X) ; X=1, Y=4(X X I) \\
X=2, & Y=2(X X I I) ; X=2, Y=3(X X I I I) \\
X=3, & Y=3(X V I)
\end{array}
$$

A ordem decrescente na facilidade de redução era 3tiacicloalcanonas (XIX - XXI), 4-tiacicloalcanonas (XXII - XXIII) e a 5-tiaciclooctanona (XVI). Os espectros no ultravioleta dos compostos estudados mostraram não serem uma simples sobreposição dos espectros de um sulfeto e uma cetona, mas que havia des locamentos batocrômicos e intensificações das bansas de absorção observadas. Estas alterações eram especialmente pronunciadas nos espectros das 3-tiacicloalcanonas (XIX - XXI). A compara ção dos potenciais de meia-onda com os respectivos espectros no ultravioleta levou os autores'a sugerir que a facilidade de redução polarogrāfica resultaria de uma interação entre o enxofre e o grupo carbonila.

Wladislaw e col. ${ }^{35}$ relataram que cetonas, substituidas em $\alpha$ por um grupo alquiltio, apresentavam diminuições de bạ sicidade quando comparadas com as anālogas não substituỉdas. Es tas diminuições eram acompanhadas por deslocamentos das bandas correspondentes ao estiramento do grupo carbonila para frequências menores. Para explicar estes fatos experimentais, os autores propuseram a existência de transferência de carga do grupo carbonila para um orbital vazio do enxofre. Não foi eliminada, entretanto, a possibilidade de estarem operando efeitos não ele trônicos, tais como impedimento estērico à formação de pontes de 
hidrogênio e perturbaçōes mecânicas originārias da substituição do hidrogênio em a por um ātomo de enxofre.

0 estudo dos espectros no ultravioleta de algumas ce tonas e derivados de ācidos carboxīlicos substituĩdos em a por enxofre foi efetuado por Wladislaw e col. ${ }^{36}$ a fim de tentar esclarecer a natureza da interação entre o grupo carbonila e o ātomo de enxofre em posição $\alpha$. Os autores observaram que a introdução de grupos alquiltio mais ramificados causava uma diminuição de intensidade e um deslocamento hipsocrōmico da transição $n \longrightarrow \pi^{*}$, em cerca de $300 \mathrm{~nm}$, quando comparada com a 4-tia hexanona-2 (XVII). Foi sugerida uma rotação restrita ao redor da ligação $c(C O)-C(\alpha)$, resultando em uma geometria desfavorāvel à interação dos orbitais ' $\mathrm{S}-\mathrm{C}_{\mathrm{CO}}$. Como um segundo māximo de absorção, observado nos espectros em aproximadamente $240 \mathrm{~nm}$, mo trava um comportamento semelhante ao da transição $n \rightarrow \pi^{*}$, Wladislaw e col. concluiram que existia uma interdependência entre as duas bandas e que a transição de menor comprimento de onda poderia ser considerada como devida a uma transferência de carga, sendo a fonte da intensidade da transição $n \rightarrow \pi^{*}$.

Snatzke e Wolfram ${ }^{37}$ estudaram, em 1972, as proprieda des quirōpticas de derivados do tiaadamantano (XXIV). A cetona (XXV) apresentava, no espectros de absorção no ultravioleta, duas bandas de mäximos em $311 \mathrm{~nm}(\varepsilon=269)$ e $254 \mathrm{~nm}(\varepsilon=324)$ cuja origem os autores explicaram pela aplicação das regras de Hudec (pāg. 7$)^{21}$. O espectro da sulfona de (XXV) tambëm mostravaduas bandas; uma $n \rightarrow \pi^{*}$ em $297 \mathrm{~nm}(\varepsilon=45)$ e outra em $248 \mathrm{~nm}(\varepsilon=83)$. A primeira estava de acordo com a expectativa pois o enxofre não possuia mais os seus pares solitärios de elētrons, porēm, a segunda somente pode ser explicada, admitindo que a ligação $S=0$ pudesse desempenhar um papel semelhante ao dos pares solitārios 
do enxofre.

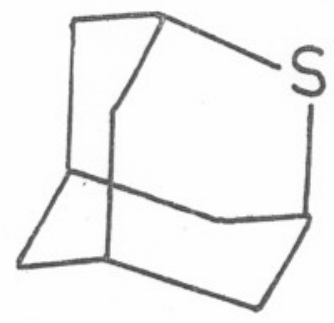

XXIV

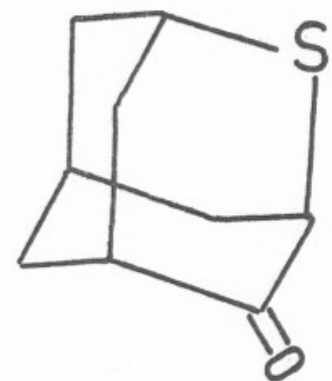

$X X V$

Cook e Djerassi ${ }^{38}$ investigaram os efeitos de oxigênio, nitrogēnio e enxofre sobre a transição $n \rightarrow \pi^{*}$ em sistemas neterocíclicos de seis membros, pela técnica do dicroismo circu $\operatorname{lar}(D C)$. A (6S)-6-metiltetrahidrotiopiranona-3 (XXVI) e o sulfóxido correspondente mostraram uma banda DC positiva devida à transição $n \rightarrow \pi^{*}$ do grupo carbonila, sinal oposto àquele observado com os anālogos de oxigēnio e nitrogênio, embora os três pertencessem à mesma sērie de antīpodas ópticos. Paralelamente o efeito Cotton era muito mais intenso no derivado contendo enxofre do que nos outros dois heterociclicos. Um efeito semelhan te tornou-se evidente nos espectros no ultravioleta onde a banda $n \longrightarrow \pi^{*}$ de (XXVI) era aproximadamente dez vezes mais intensa ( $305 \mathrm{~nm}, \varepsilon=178$ ) do que dos anảlogos com oxigênio e nitrogênio. As bandas DC negativas do $\beta$-cetosulfeto (XXVI) e de seu sulfóxido em 250 e $240 \mathrm{~nm}$, respectivamente, resultariam, segundo os autores, de uma transição eletrōnica do enxofre, provavelmente $n \rightarrow \sigma^{*}$.

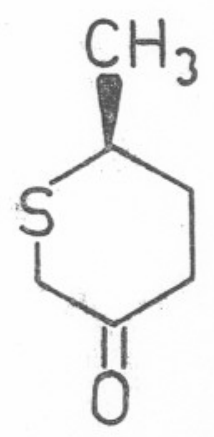

$X X V I$
BIBLIOTECA

Instituto de Química Univarsidado de São Paule 
A sulfona da (6S)-6-metiltetrahidrotiopiranona-3 mostrou apenas um efeito Cotton positivo em $305 \mathrm{~nm}$ de força rotacional reduzida. Tambēm a sua transição $n \rightarrow \pi^{*}$ era de intensida de muito menor do que a observada em (XXVI). Em comprimentos de onda menores do que $270 \mathrm{~nm}$ não foram observadas bandas de absor ção. Os autores concluiram que os efeitos cotton observados em (XXVI) e em seu sulfōxido indicariam claramente uma interação entre o enxofre e o grupo carbonila.

As absorções no ultravioleta e infravermelho de algumas 3-tiacicloalcanonas, bem como as constantes de equilíbrio para os complexos de associação formados com p-clorofenol, determinadas pela espectroscopia de ressonância magnētica protôn i ca, sugeriram interações entre o enxofre e o grupo carbonilanos estados fundamental e excitado ${ }^{39}$. Os dados experimentais indica ram que estas interações são diferentes do tipo transanular des critas para a 5-tiaciclooctanona (XVI) ${ }^{31}$. Buzzi et al. 39 concluiram que os resultados sugeriam interações de doação e retro-doação entre o enxofre e o grupo carbonila, dependentes das conformações moleculares, porēm, não eram suficientes para dec dir quais orbitais mais contribuiam e se as interações eramatra vēs do espaço ou atravēs das ligações.

01 ivato et al. ${ }^{40}$ estudaram os espectros fotoeletrôn co e no ultravioleta da 4-tiapentanona-2 (XXVII).0 seu primeiro potencial de ionização era de $8,84 \mathrm{eV}$ (par solitārio do enxofre) enquanto que a segunda banda fotoeletrônica localizava-se em 9,90 eV (par solitārio do oxigênio do grupo carbonila). A comparação com os potenciais de ionização do 2 -tiapentano $(8,49 \mathrm{eV}) \mathrm{e}$ da 2-pentanona $(9,45 \mathrm{eV})$ mostrou que tanto o par solitārio de elētrons do enxofre como do grupo carbonila foram estabilizados. Os autores sugeriram que nenhuma conclusão definitiva poderia 
ser dada sem cálculos mecânico-quânticos refinados

$$
\mathrm{CH}_{3} \mathrm{SCH}_{2} \mathrm{COCH}_{3}
$$

$(X X V I I)$

As bandas de absorção no espectro ultraviolta de (XXVII) em 302 e $240 \mathrm{~nm}$ foram atribuídas à transição $n \rightarrow \pi^{*}$ do grupo carbonila e a transição de camada de valência $\left(n \rightarrow \sigma^{*}\right)$ do enxofre, respectivamente. Estes dados juntamente com os po tenciais de ionização indicariam, segundo os autores, um alto grau de influência mütua entre os orbitais $\pi^{*}$ e $\sigma^{*}$ Uma inversão das transições ou seja a banda em $240 \mathrm{~nm}$ corresponder à transição $n \rightarrow \pi^{*}$ e vice-versa para a $n \rightarrow \sigma^{*}$, parecia pouco provāvel, porēm, a pouca informação sobre a interação entre os orbitais excitados, não permitiu a 01 ivato et al. excluir completamente esta interpretação.

Em 1977, Cole et ar. ${ }^{41}$ analisaram os potenciais de ionização da 4-tiapentanona-2 (XXVII) correspondentes aos pares solitärios do enxofre $(8,84 \mathrm{eV})$ e do oxigênio carbonilico $(9,90 \mathrm{eV})$ que indicaram uma estabilização nos dois casos Uma estimativa dos potenciais de ionização de cada àtomo em questão, considerando os efeitos indutivos mútuos do grupo carbonila e do átomo de enxofre, resultou em $9,75 \mathrm{eV}$ (oxigēnio carbonilico) e 9,17 eV (ätomo de enxofre), respectivamente. Estes, quando comparados com os valores experimentais, mostraram que realmente houve uma desestabilização do nível eletrônico no enxofre e uma estabilização do nível eletrônico no oxigênio. Baseados neste resultado, os autores sugeriram uma interação atravēs do espaço entre o en xofre e o grupo carbonila.

Recentemente ${ }^{42}$, foi determinado o espectro no ultra- 
violeta afastado da 4-tiapentanona-2(XXVII) e os resultados suge riram que existia pelo menos uma transição $n \rightarrow \sigma^{*}$ na região de $240 \mathrm{~nm}$, separada de uma do tipo Rydberg $n \rightarrow 4 s$, ambas envolvendo o enxofre. Nos espectros de sulfetos de alquila simples exís tiam indicações para as mesmas transições, porēm no composto es tudado as duas bandas apareceram claramente separadas. As bandas fotoeletrōnicas de (XXVII) influenciadas pela interação entre os orbitais dos pares solitārios deslocaram-se para energias maiores, enquanto que as bandas $n \rightarrow \sigma^{*}$ e $n \rightarrow \pi^{*}$ se desloca ram em sentido contrārio. 


\section{RESULTADOS E DISCUSSAO}

\subsection{INTRODUCCAO}

A posição e intensidade das bandas de absorção $n \rightarrow \pi *$ do grupo carbonila em cetonas substituidas dependem acentuadamente das conformações moleculares (ver referências 16, 17, 21 e 23 por exemplo). Os espectros no ultravioleta de cetonas $\alpha-a$ l quiltiosubstituidas apresentam duas bandas de absorção nas regiões de 295 a $300 \mathrm{~nm}(\varepsilon=300)$ e de 240 a $245 \mathrm{~nm}(\varepsilon=400)$ e a sua existências fôra explicada pela interação entre o átomo de enxo fre e o grupo carbonila ${ }^{30}$. Wladislaw e col. ${ }^{36}$, estudando os espectros eletrônicosde compostos carbonilicos com diferentes gr pos alquiltio ligados ao carbono a em relação ao grupo carboni1a, sugeriram que a interação entre o enxofre e o grupo carboni la dependia das conformações das moléculas consideradas.

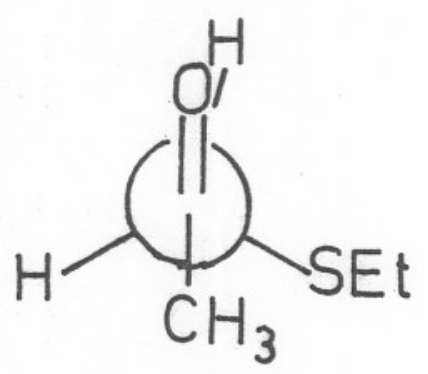

XXVIII a

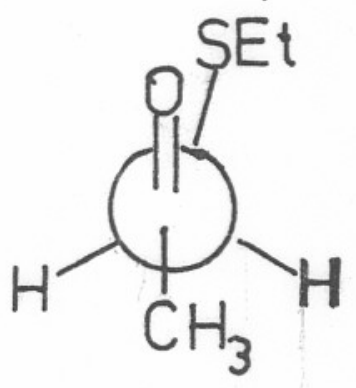

b

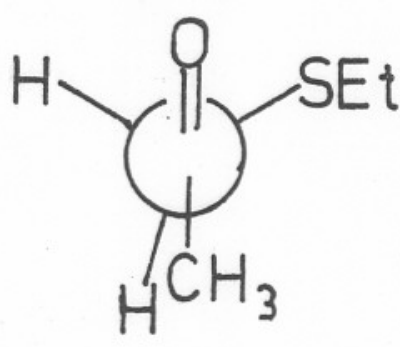

C

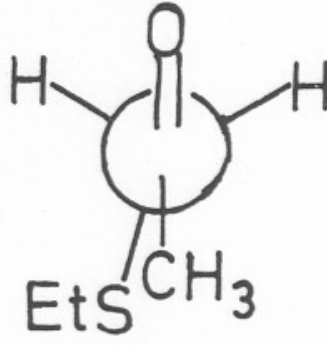

d

Assim, das quatro conformações possiveis (XXVIIIa-d), duas foram sugeridas (XXVIIIb-C), nas quais as interações ocorreriam, porém, tratando-se de compostos acíclicos, não foi possivel estabelecer em qual das duas a interação seria mais impor tante.

Era, pois, de interesse estudar cetonas ciclicas $\alpha-a]$ quiltiosubstituídas em que a estereoquimica fosse bem definida, 
a fim de poder avaliar melhor a influência das posições relativas dos ātomos de enxofre e grupo carbonila sobre a posição e intensidade das bandas de absorção no ultravioleta e, consequen temente, obter informações sobre a natureza das interações envolvidas.

\subsection{RESULTADOS}

As primeiras cetonas cỉclicas a-alquiltiosubstituídas que pareciam de interesse em nosso estudo eram as derivadas da ciclohexanona, pois os seus $\alpha$-halogenoderivados foram objeto de estudo por värios anos ${ }^{43}$ e uma variedade de tēcnicas foram em pregadas a fim de estimar as populações relativas de suas conformações axiais e equatoriais. Foram preparadas, por mētodos convencionais descritos na literatura, as 2-metiltio- $(X X I X)^{44}$, 2-etiltio- $(X X X)^{45}$ e 2-t-butiltiociclohexanonas (XXXI) 46 e os seus espectros no ultravioleta, determinados em n-hexano e meta nol absolutos, estão nas figuras 4,5 e 6 , respectivamente.

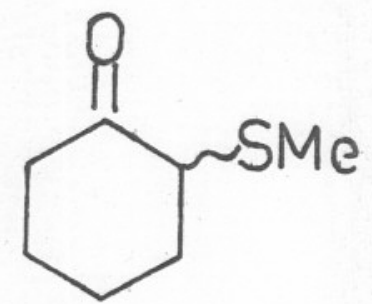

XXIX

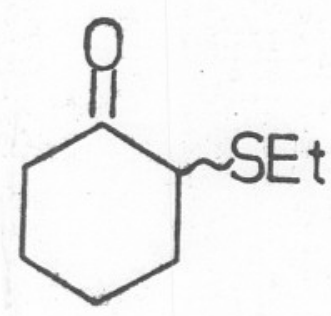

$x x x$

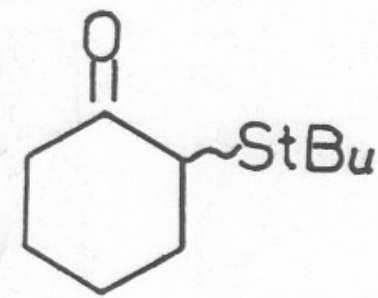

$X X X I$

0 estudo da banda de estiramento do grupo carbonila, em $\mathrm{CCl}_{4}$, de (XXIX) no infravermelho mostrou que a cetona considerada era constituída de aproximadamente $70 \%$ do confōrmero XXIXa e $30 \%$ do confôrmero XXIXb, o que̊ corresponde às populações relativas determinadas para a 2-clorociclohexanona ${ }^{43}$. 


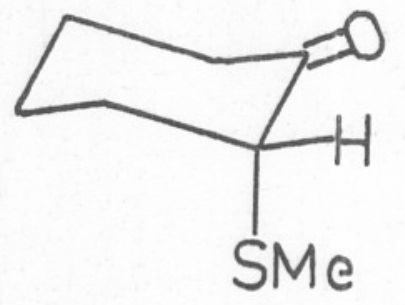

a

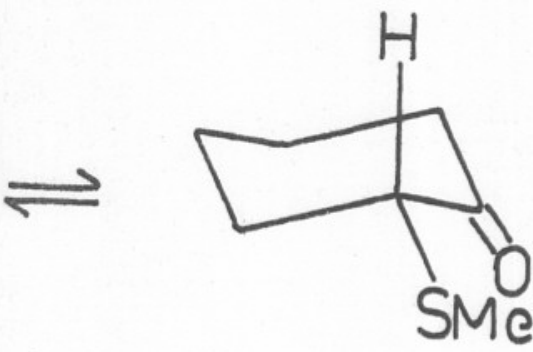

b

Os espectros no ultravioleta dos três compostos mostram a existência de duas bandas de absorção, uma em aproximada mente $305 \mathrm{~nm}$ e outra em cerca de $250 \mathrm{~nm}$.

$\mathrm{Na}$ 2-metiltiociclohexanona (XXIX, fig. 4) ē observado um deslocamento hipsocrômico de $307 \mathrm{~nm}$ para $305 \mathrm{~nm}$ ao passar de n-hexano para o metanol, porēm, as intensidades das duas bandas $\left(\varepsilon_{\max }\right)$ praticamente são iguais, 236 e 241 , respectivamente. A posição da banda em $248 \mathrm{~nm}$ não ē afetada pela mudança de solvente, porēm, observa-se um decrēscimo da intensidade da mesma de $\varepsilon_{248}=335$ para $\varepsilon_{248}=262$ ao passar de $n$-hexano para 0 metanol.

Os espectros da 2-etiltiociclohexanona (XXX, fig.5), em $n$-hexano e metanol, apresentam caracteristicas semelhantes àquelas do composto $(X X I X)$ : um pequeno deslocamento hipsocrômico de $309 \mathrm{~nm}$ ( $\mathrm{n}$-hexano, considerando o centro da banda) para $306 \mathrm{~nm}$ (metanol) e um pequeno aumento da intensidade $(\varepsilon)$ de 256 ( $n$-hexano) para 286 (metanol). A banda em comprimento de onda menor desloca-se de $248 \mathrm{~nm}(\mathrm{n}$-hexano) para $250 \mathrm{~nm}$ (metanol) e apresenta um pequeno efeito hipsocrômico ao passar de $n$-hexano $\left(\varepsilon_{248}=321\right)$ para o metanol $\left(\varepsilon_{250}=282\right)$.

Em n-hexano, o espectro da 2-t-butiltiociclohexanona (XXXI, fig.6) apresenta uma banda de absorção centrada em $307 \mathrm{~nm}$ ( $\varepsilon=222$ ) e outra em $242 \mathrm{~nm}(\varepsilon=405)$ enquanto que, em metanol, as 
27.

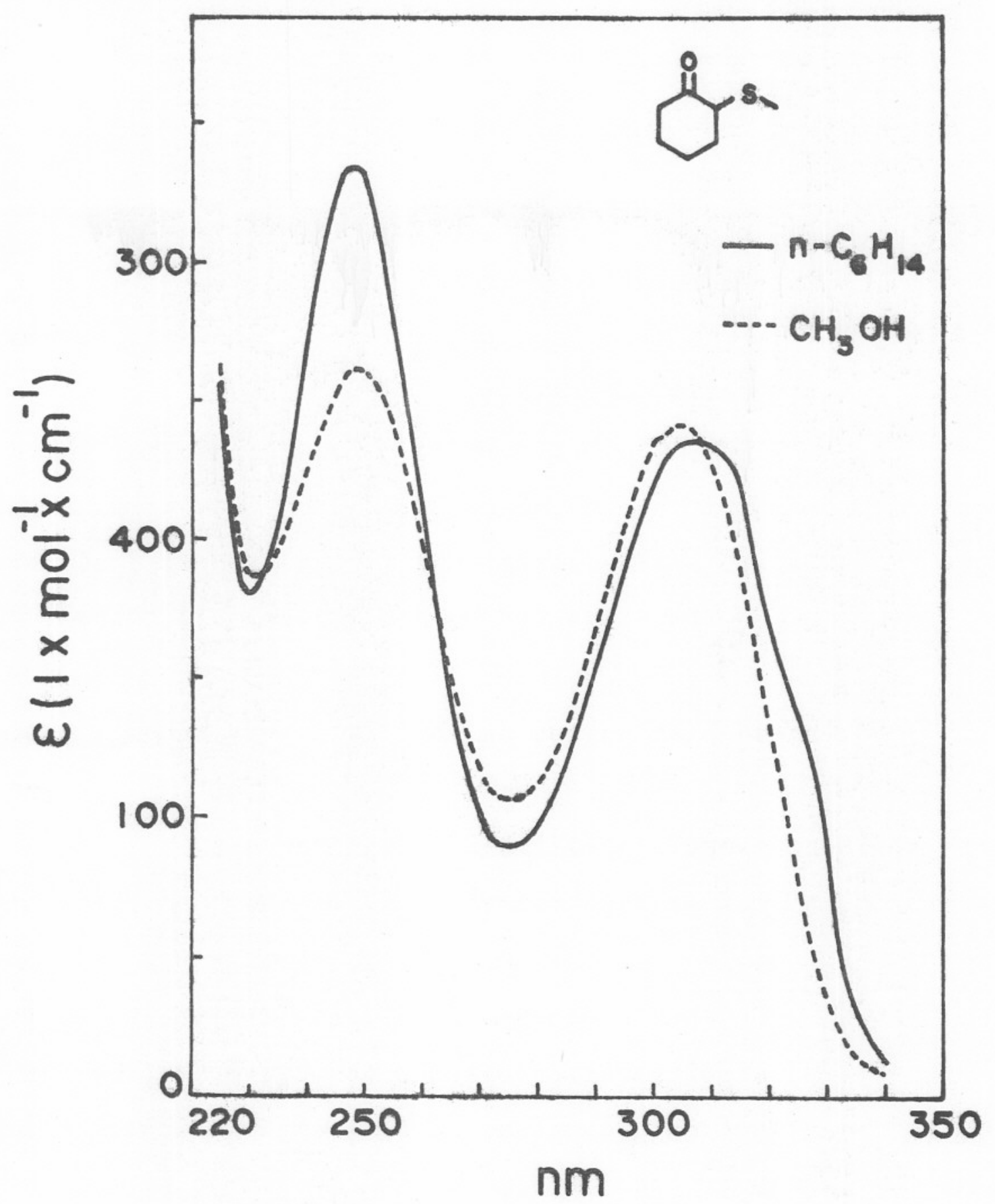

Fig. 4 - Espectros no ultravioleta da 2-metiltiociclohexanona (XXIX) em n-hexano e metanol. 


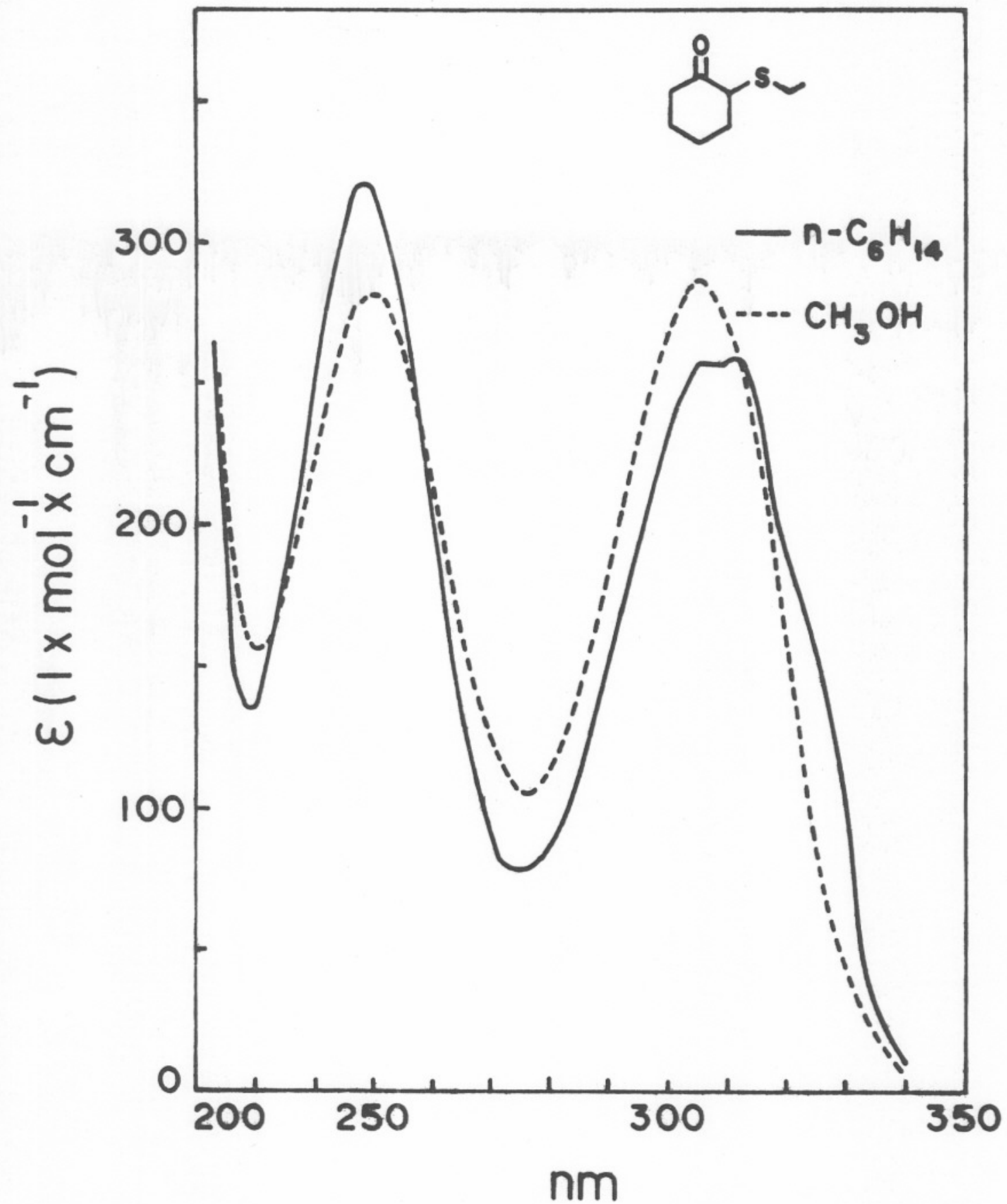

Fig. 5 - Espectros no ultravioleta da 2-etiltiociclohexanona $(X X X)$ em $n$-hexano e metanol. 


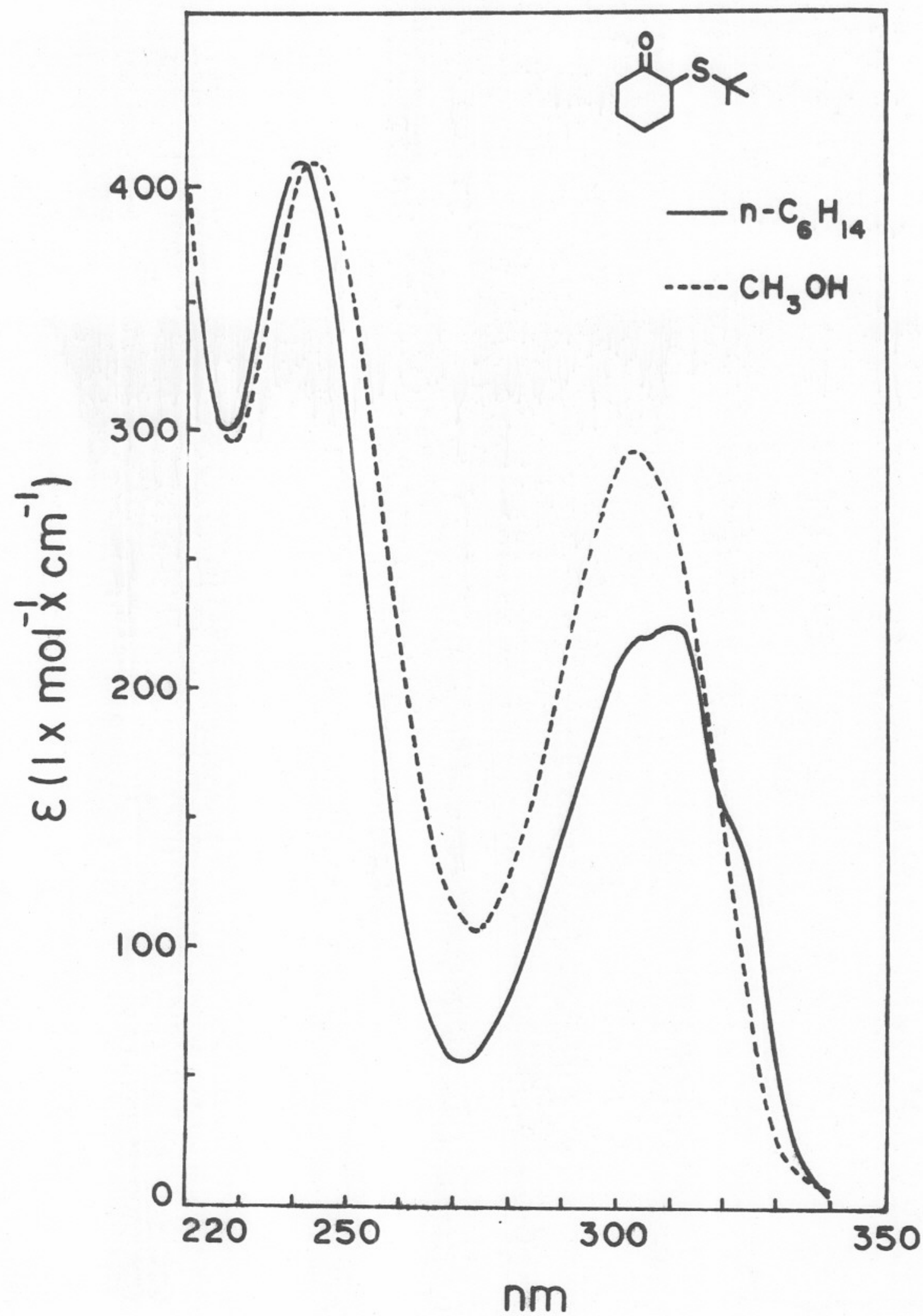

Fig. 6 - Espectros no ultravioleta da 2-t-butiltiociclohexanona (XXXI) em $n$-hexano e metanol. 
duas bandas de absorção estão localizadas em $303 \mathrm{~nm}(\varepsilon=292)$ e $244 \mathrm{~nm}(\varepsilon=405)$. Observa-se que o deslocamento hipsocrōmico da banda em comprimento de onda maior è mais pronunciado do que nos compostos $(X X I X)$ e $(X X X)$, como também o efeito hipercrómico nes ta banda é maior do que nos outros dois compostos estudados. A banda em comprimento de onda menor apresenta um deslocamento ba tocrōmico ao mudar do solvente apolar para o polar prötico, porēm não hā mudança na intensidade contrariamente à 2-metiltioc clohexanonas $(X X I X)$ e $\bar{a} 2$-etiltiociclohexanona (XXX) em que um efeito hipocrômico é observado.

E interessante observar que a estrutura vibracional das bandas de absorção em n-hexano, em comprimento de onda maior, apresenta-se mais definida no caso de 2-t-butiltiociclohexanona $(X X X I)$ do que em $(X X I X)$ e $(X X X)$.

Como Trost e col. ${ }^{44}$ mostraram que um grupo $\alpha$-metiltio interagia com um grupo carbonila de tal forma que a conformação axial daquele era favorecida por $0,4 \mathrm{kcal} / \mathrm{mol}$, achamos de interesse preparar a 2-etiltio-2-metilciclohexanona (XXXII), com posto não descrito na literatura, em que a posição axial do gru po etiltio seria mais favorecida devido ao fato da interação 1,3 do grupo metila axial envolver uma energia maior do que a de um substituinte alquiltio no ciclohexano 47 a.

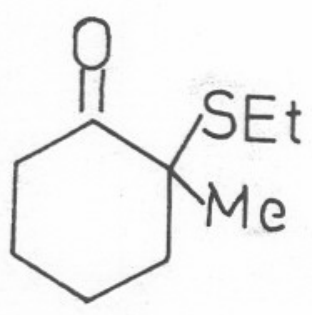


Os espectros no ultravioleta, em n-hexano e metanol absolutos, de (XXXII) estão na figura 7. A banda de absorção em comprimento de onda maior centrada em $307 \mathrm{~nm}(\varepsilon=245)$, no solven te apolar, ē deslocada para $305 \mathrm{~nm}$ em metanol e um pronunciado efeito hipercrômico è observado ( $\left.\varepsilon_{245}=362\right)$. Em $249 \mathrm{~nm}(\varepsilon=307)$ localiza-se uma segunda banda em n-hexano que, ao passar para o solvente polar, ē deslocada para $252 \mathrm{~nm}(\varepsilon=330)$ acompanhado de um ligeiro efeito hipercrōmico.

Com a finalidade de melhor compreender os espectros no ultravioleta dos compostos XXIX - XXXII decidimos preparar dois $\alpha$-alquiltioderivados da 4-t-butilciclohexanona: 2-metiltio(XXXIII) e 2-etiltio- (XXXIV), compostos não descritos na literatura.

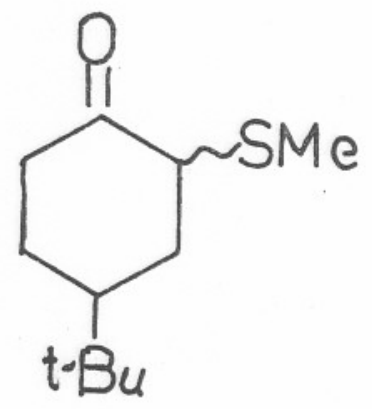

XXX I I I

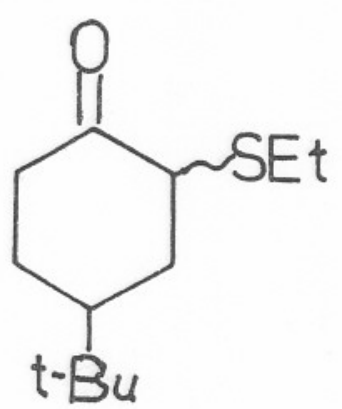

XXXIV

Nestes compostos a presença do grupo t-butila preferencialmente na posição equatorial 47 bermitiria, em princípio, isolar dois estereoisômeros, um com o grupo alquiltio em posição equatorial (diastereômero cis, XXXVa) e outro com o mesmo grupo em posição axial (diastereômero trans, XXXVb).

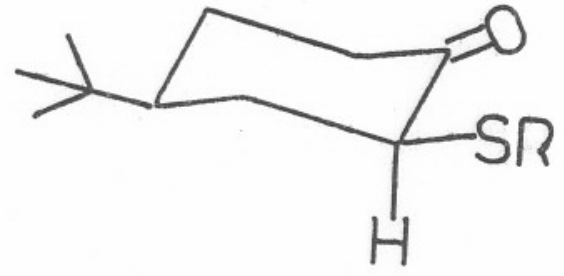

a

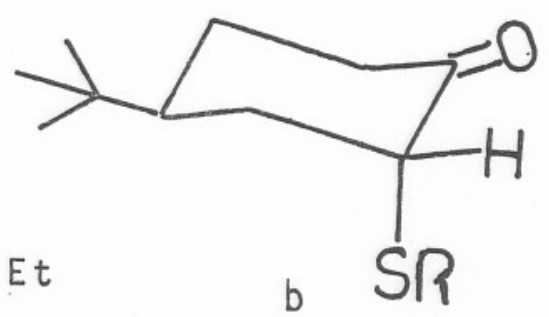

$X X X V$ 


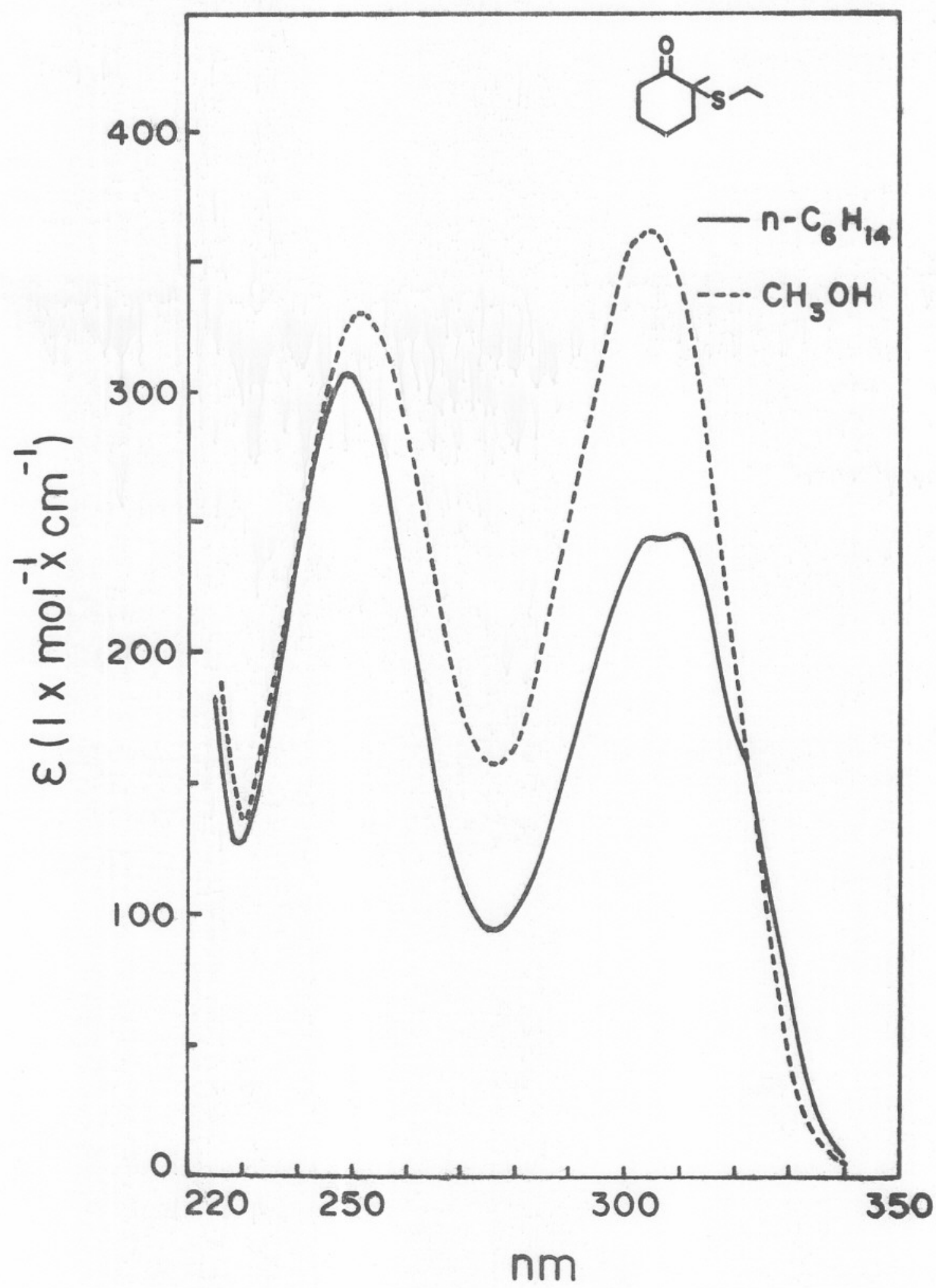

Fig. 7 - Espectros no ultravioleta da 2-etiltio-2-metilciclohexanona (XXXII) em $n$-hexano e metanol. 
0 composto (XXXIII) foi obtido pela reação de sulfenilação do enolato de lîtio da 4-t-butilciclohexanona com dissulfeto de dimetila ${ }^{44}$. As anālises dos espectros de rmp e de I.V. do composto puro obtido revelaram que (XXXIII) era constituido de aproximadamente $60 \%$ de XXXVb e $40 \%$ de XXXVa. Não foi possivel separar os dois diastereōmeros que nas anālises de cro matografia lîquido-gās em diferentes colunas cromatogräficas apre sentavam os mesmos tempos de retenção.

A 2-etiltio-4-t-butilciclohexanona (XXXIV) foi prepa rada pela reação da 2-cloro-4-t-butilciclohexanona (XXXVI) com etanotiolato de sōdio. Uma mistura dos diastereōmeros cis e trans de (XXXVI) fora obtida por Allinger e col. ${ }^{48}$ pela reação de cloro com a 4-t-butilciclohexanona em ácido acético $90 \%$. Os autores separaram os diastereômeros por destilação fracionada.

A fim de tentar obter diferentes relações entre os diastereômeros (XXXVa e b, R=Et) da 2-etiltio-4-t-butilciclohe xanona (XXXIV) reagimos o etanotiolato de sódio com as cis- e trans-2-cloro-4-t-butilciclohexanonas puras respectivamente, po rēm, em ambas as reações os espectros de rmp dos produtos obtidos mostraram-se idēnticos e não foi possível separaros diastẹ reômeros formados.

Os espectros no ultravioleta de (XXXIII) e (XXXIV) são mostrados nas figuras 8 e 9 , respectivamente. Em $n$-hexano (XXXIII) apresenta uma banda de absorção centrada em 308 nm $(\varepsilon=247)$ que é deslocada para $305 \mathrm{~nm}(\varepsilon=320)$ em metanol com um efeito hipercrômico. A banda em comprimento de onda menor apresenta inflexões tanto em n-hexano como em metanol, porēm o māxi mo em ambos os casos situa-se em $242 \mathrm{~nm}$ e com praticamente a mes ma intensidade $(\varepsilon \approx 355)$. A 2-etiltio-4-t-butilciclohexanona apre senta uma banda em $308 \mathrm{~nm}(\varepsilon=280)$ e $305 \mathrm{~nm}(\varepsilon=320)$ em $n$-hexano 


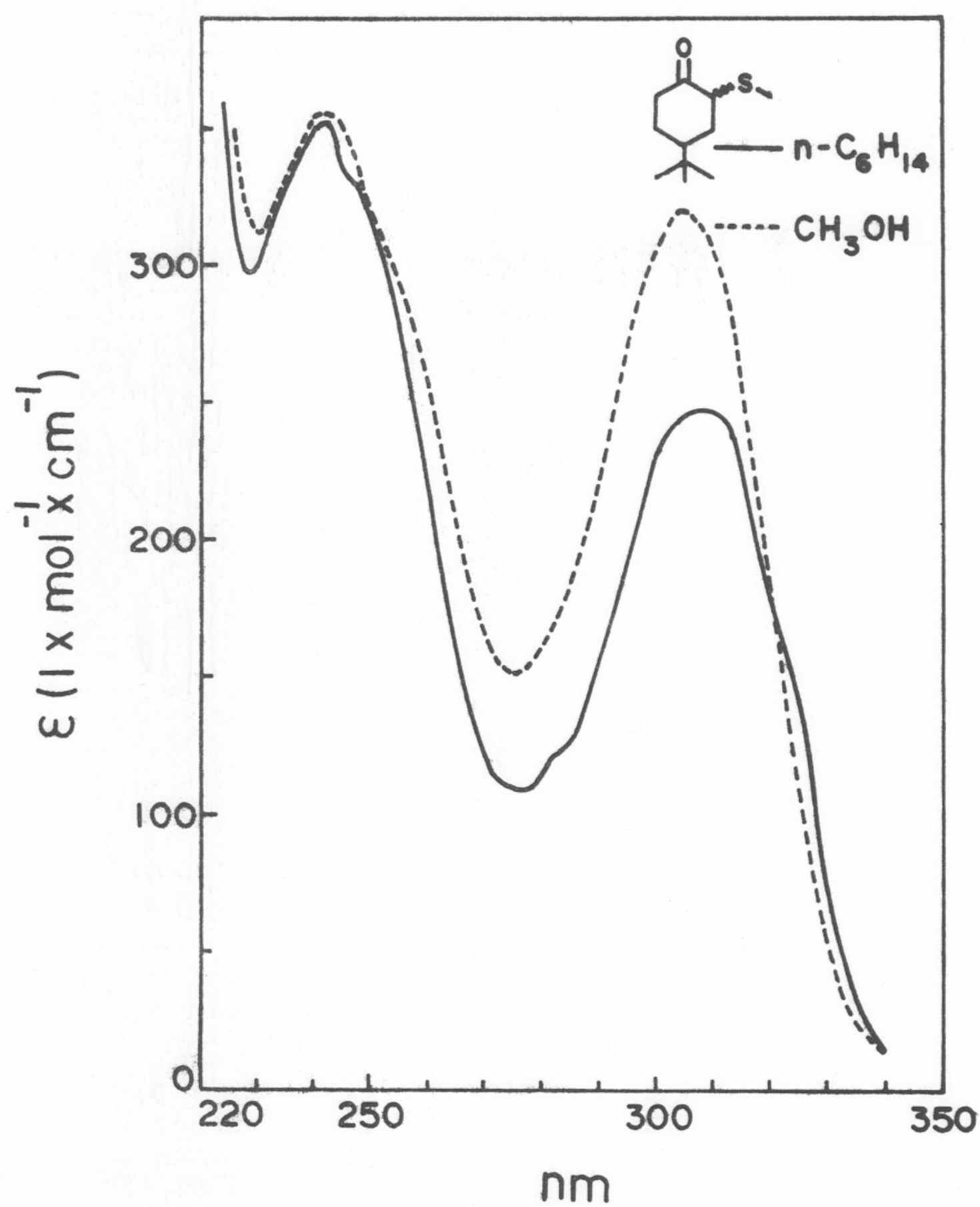

Fig. 8 - Espectros no ultravioleta da 2-metiltio-4-t-butilciclo hexanona (XXXIII) em n-hexano e metanol. 


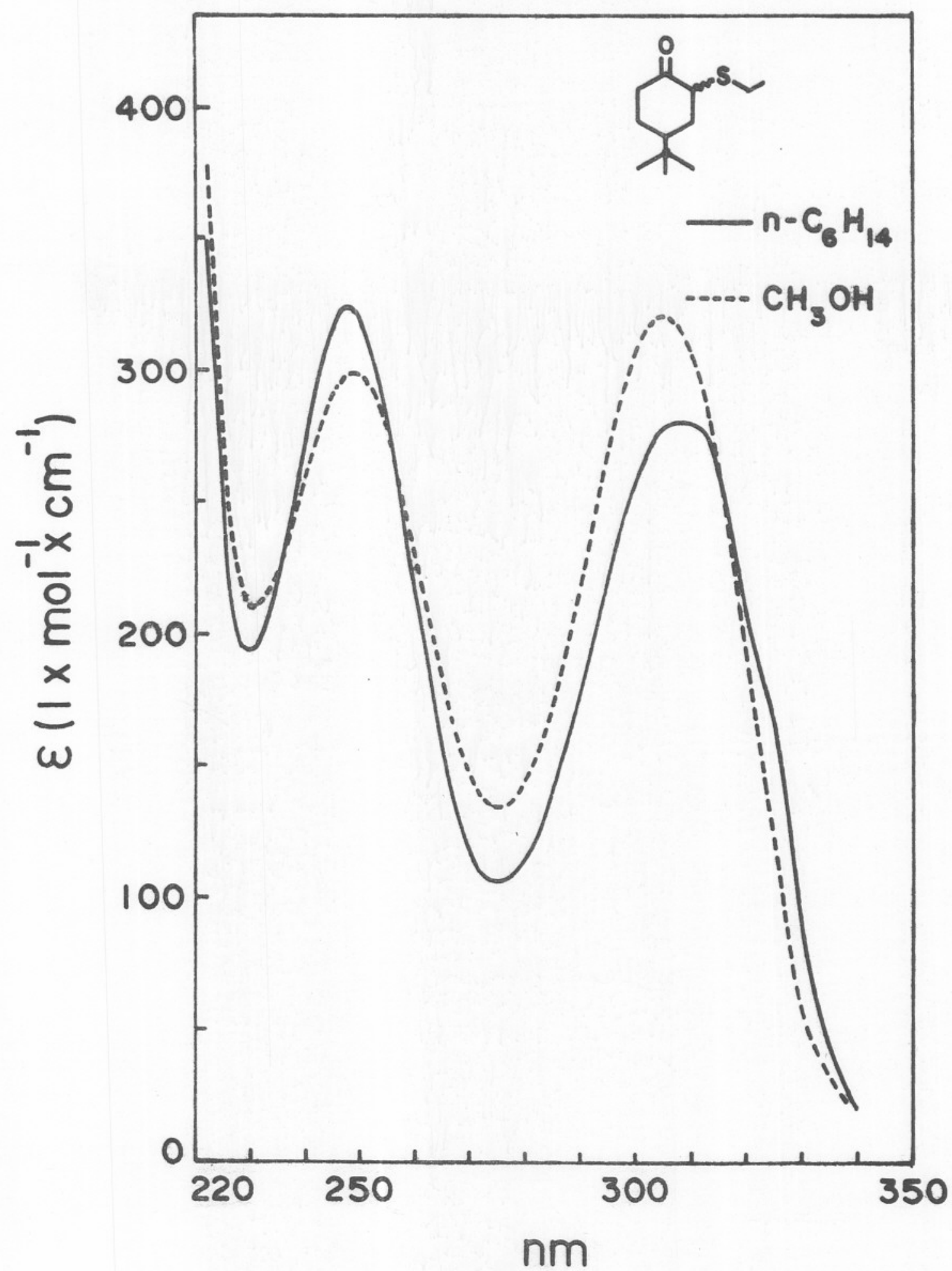

Fig. 9 - Espectros no ultravioleta da 2-etiltio-4-t-butilciclohexanona (XXXIV) em n-hexano e metanol. 
e metanol, respectivamente, e outra em $248 \mathrm{~nm}(\varepsilon=324)$ e $249 \mathrm{~nm}$ $(\varepsilon=298)$ nos mesmos solventes, respectivamente.

Tendo em vista que nas cetonas $\alpha$-alquiltiosubstituidas (XXIX - XXXIV) os confôrmeros (XXIX - XXXII) ou então os dias tereômeros (XXXIII - XXXIV) apresentavam os grupos a-alquiltio preferencialmente em posições axiais e como não fora possīvel se parar os estereoisōmeros de (XXXIII) e (XXXIV), era de interesse sintetizar uma cetona em que o grupo alquiltio ocuparia somente, ou então preferencialmente, uma posição equatorial. Trost e col. ${ }^{44}$ descreveram a sintese da octahidro-4a-metil-3-metiltio-2-(1H)-naftalenona (XXXVII) e isolaram como produto principal o diastereômero com o grupo metiltio em posição equatorial.

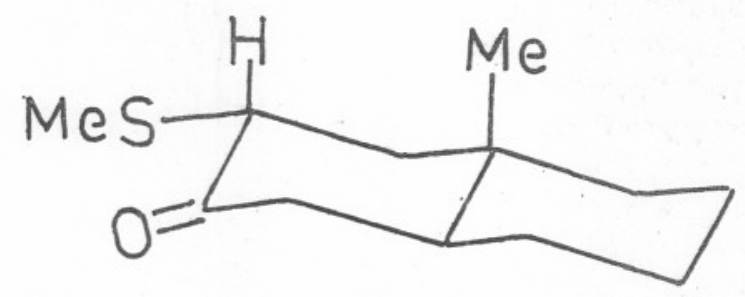

a XXXVI I

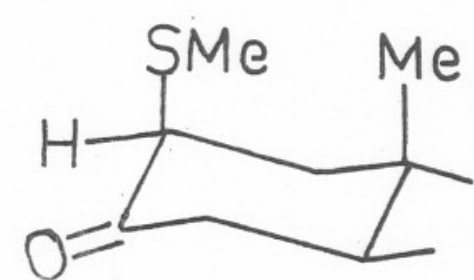

b

A estrutura proposta pelos autores foi baseada no es pectro de rmp em que era observado o sinal correspondente ao prō ton do grupo OCCHS como um duplo duplete $(\delta 3,43)$. 0 composto (XXXVII) por nōs sintetizado, de maneira anāloga a de Trost e col., apresentou, no espectro de rmp, um duplo duplete $(\delta 3,49)$ com J $=12$ e $6 \mathrm{~Hz}$ correspondente a $0,7 \mathrm{H}$ e ummultiplete $(\delta \quad 3,07)$ correspondente a $0,3 \mathrm{H}$ (fig. 10). Atribuimos o sinal em campo mais baixo ao próton axial do carbono 3 enquanto que o sinal em campo mais alto corresponderia a um próton equatorial ligado ao mesmo carbono. Esta atribuição está de acordo com a de Casadevall e col.$^{49,50}$ para as 3-bromo e 3-clorooctahidro-4a-metil-2 


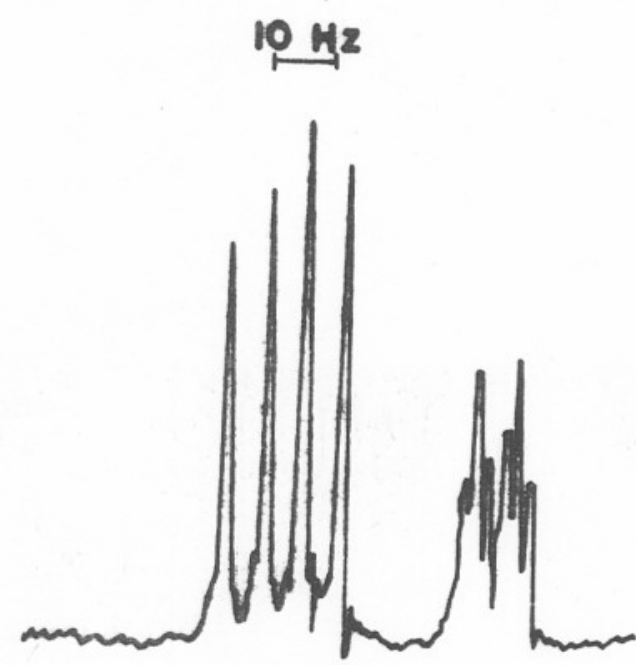

A

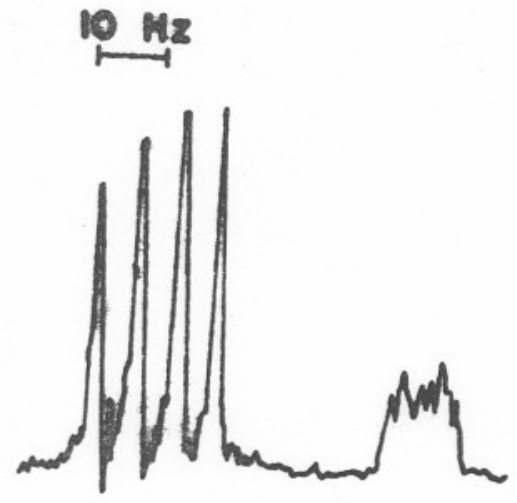

$B$

Fig. 10 - Espectros de rmp $(X L-100)$ na região de $\delta 3,00$ (ref. TMS) de: $A$ - Octahidro-4a-metil-3-etiltio-2(1H)-naf talenona (XXXVIII) em $\mathrm{CCl}_{4}$. B - Octahidro-4a-metil-3-metiltio-2(1H)-naftalenona (XXXVII) em $\mathrm{CDCl}_{3}$. 
(1H)-naftalenonas anālogas ao composto (XXXVII). Outras evidências do espectro de rmp suportam as nossas conclusões: dois sin gletes $(\delta 2,06$ e 2,02) correspondentes aos prótons do grupo metiltio e dois singletes $(\delta 1,13$ e 1,09 ) correspondentes ao grupo metila da junção dos anēis da octahidro-4a-metil-2(1H)-naftạ lenona 49,50 . Concluimos, portanto, que a octahidro-4a-metil-3metiltio-2(1H)-naftalenona por nōs obtida era constituida de uma mistura de dois diastereômeros: $75 \%$ de (XXXVIIa) e $25 \%$ de (XXXVIIb).

A preparação da octahidro-4a-metil-3-etiltio-2(1H)naftalenona (XXXVIII), não descrita na literatura, pela. reação de etanotiolato de sódio com a trans-3-bromo-trans-10-metil-2decalona (XXXIX) resultou em.uma mistura de $64 \%$ de (XXXVIIIa) e $36 \%$ de (XXXVIIIb), valores estes determinados a partir do espec tro de rmp (fig. 10).

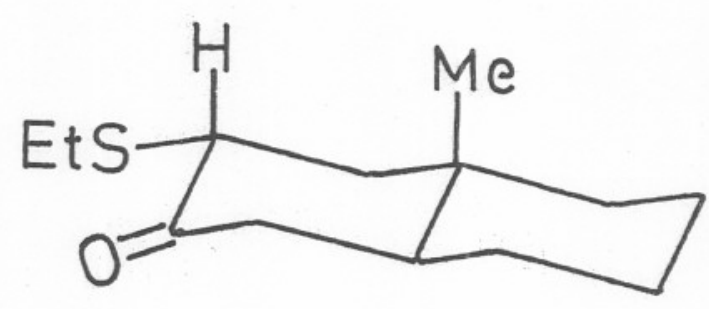

a

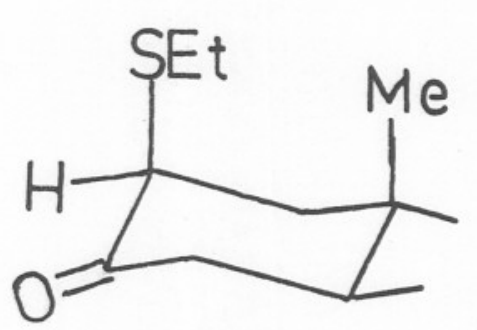

b

$X X X V I I I$

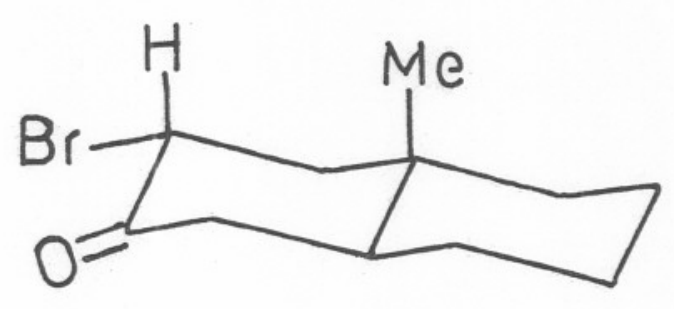

XXXIX

Também neste caso a existência de uma mistura de diastereômeros fica evidenciada pela existência de outros sinais no espectro de rmp : dois quartetos sobrepostos $(\delta 2,47$ e 2,39, 
$J=7 \mathrm{~Hz}$ ) correspondentes ao $\mathrm{SCH}_{2} \mathrm{CH}_{3}$ e dois singletes $(\delta, 1,11$ e $1,05)$ correspondentes aos $\mathrm{CH}_{3}$ da junção dos anēis da cetona estudada. 0 espectro de $r m{ }^{13} \mathrm{C}$ de (XXXVIII) apresenta dois sinais correspondentes ao carbono carbonîlico ( $\delta 202,9$ e 203,3) com uma relação de intensidade de 2:1.

Os espectros no ultravioleta de (XXXVII) e (XXXVIII), em n-hexano e metanol absolutos, encontram-se nas figuras 11 e 12, respectivamente. $\mathrm{Na}$ octrahidro-4a-meti1-3-metiltio-2(1H)-naf talenona (XXXVII) duas bandas de absorção são observadas: uma na região de $300 \mathrm{~nm}$ e outra na região de $245 \mathrm{~nm}$. A banda em com primento de onda maior apresenta um deslocamento hipsocrâmico ao passar de $n$-hexano (304 nm) para o metanol (301 nm) e um efeito hipocrômico $\left(\varepsilon_{304}=170\right.$, n-hexano; $\varepsilon_{301}=149$, metanol $)$. Tambēm é observado um deslocamento hipsocrōmico da segunda banda de $246 \mathrm{~nm}$ (n-hexano) para $244 \mathrm{~nm}$ (metanol) acompanhado de um efeito hipocrômico $\left(\varepsilon_{246}=284, n\right.$-hexano; $\varepsilon_{244}=255$, metanol). Os espectros da octahidro-4a-metil-3-etiltio-2(1H)-naftalenona (XXXVIII) mos tram características semelhantes às descritas acima. A banda em $304 \mathrm{~nm}$ em $\mathrm{n}$-hexano se desloca para $302 \mathrm{~nm}$ em metanol e hā uma dị minuição de intensidade de $\varepsilon_{304}=286$ para $\varepsilon_{302}=237$. Mudando 0 solvente de $n$-hexano para o metanol tem como consequência um des locamento hipsocrômico da banda em $244 \mathrm{~nm}$ para $241 \mathrm{~nm}$ e um efe to hipocrômico $\left(\varepsilon_{244}=377\right.$ para $\left.\varepsilon_{241}=332\right)$.

As conformações das $\alpha$-cloro e $\alpha$-bromociclopentanonas foram estudadas por Brutcher e col. ${ }^{51}$ pela espectroscopia no in fravermelho e os autores concluiram que os halogênios possuiam um carāter quasi-axial.

Um estudo da banda de estiramento do grupo carbonila

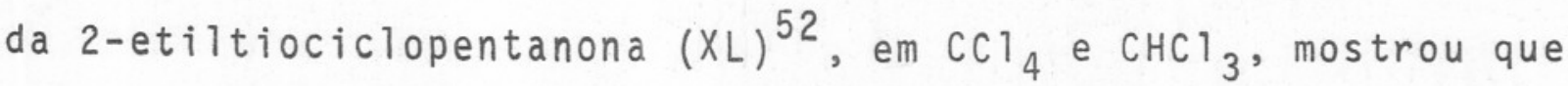
a mesma era constituỉda de dois confôrmeros: um com o grupo eti 1 


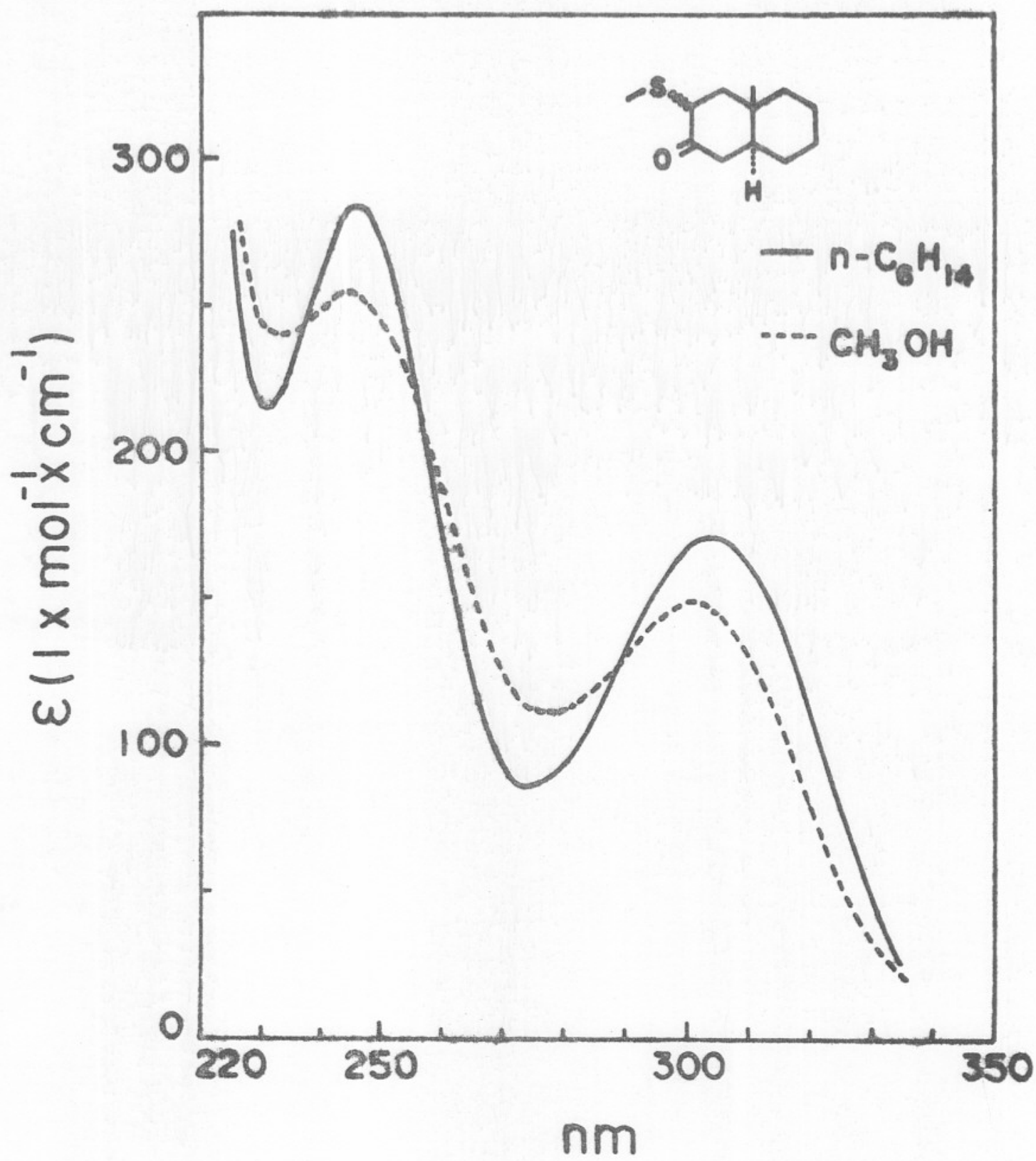

Fig. 11 - Espectros no ultravioleta da octahidro-4a-metil-3-metiltio-2(1H)-naftalenona (XXXVII) em n-hexano e metanol. 


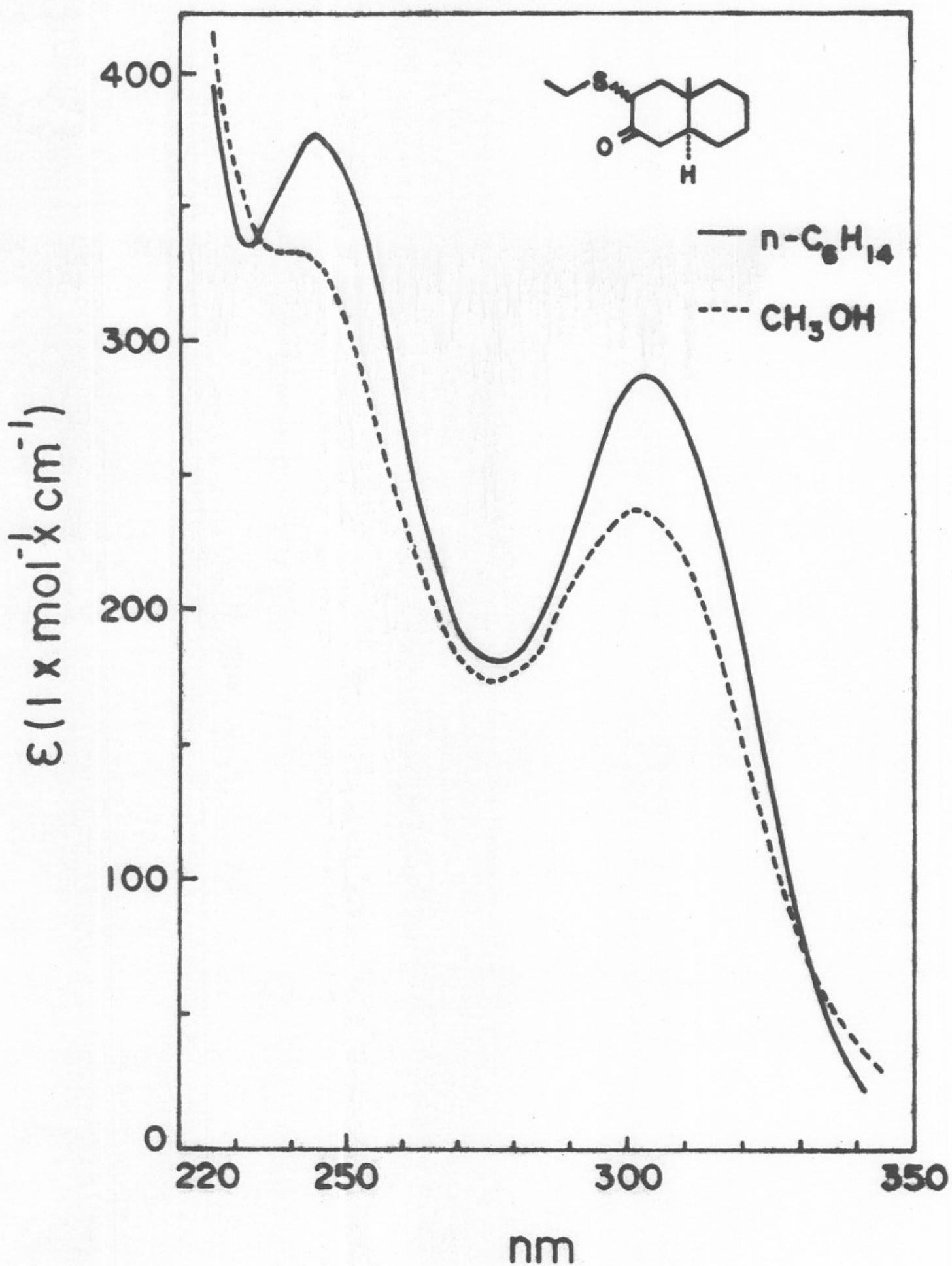

Fig. 12 - Espectros no ultravioleta da octahidro-4a-metil-3etiltio-2(1H)-naftalenona (XXXVIII) em n-hexano e metanol. 
tio em posição quasi-axial e outro com o substituinte em posição equatorial. As porcentagens do primeiro em $\mathrm{CCl}_{4} \mathrm{e} \mathrm{CHCl}_{3}$ eram de $83 \%$ e $73 \%$, respectivamente.

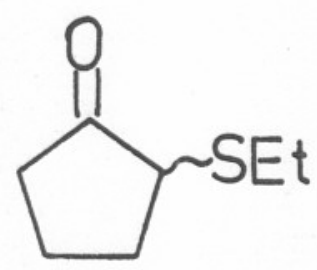

$X L$

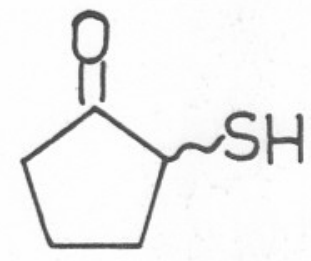

$X L I$

Os espectros no infravermelho de 2-mercaptociclopentanona (XLI) 52 mostraram tanto na região de absorção do. grupo S-H $\left(2570 \mathrm{~cm}^{-1}\right)$ como na do grupo carbonila $\left(1740 \mathrm{~cm}^{-1}\right)$ duas conformações, uma das quais ẹra associada intramolecularmente por ponte de hidrogēnio e corresponderia a uma conformação quasei-equatorial. No outro confôrmero não existiria nenhuma associação intramolecular, porém o grupo S-H estaria mais prōximo de uma conformação equatorial do que axial. A existência de pontes de hidrogênio intramoleculares entre os grupos S-H e carbonila fora sugerida por Wladislaw e col. ${ }^{53}$ no caso de $\alpha$-mercaptoésteres sendo comprovada no presente trabalho ${ }^{52}$. As porcentagens da conformação associada, em $\mathrm{CCl}_{4}$ e $\mathrm{CHCl}_{3}$, eram de $55 \%$ e $52 \%$, respectivamente.

Os espectros no ultravioleta de (XL) e (XLI) estão nas figuras 13 e 14 . Como no caso das a-alquiltiocetonas, anteriormente estudadas, a 2-etiltiociclopentanona (XL) apresenta duas bandas de absorção na região de 220 a $350 \mathrm{~nm}$. Em n-hexano, a banda em comprimento de onda maior encontra-se em $310 \mathrm{~nm}(\varepsilon=495)$ e é deslocada para $308 \mathrm{~nm}(\varepsilon=365)$ quando o solvente è metanol.A banda em comprimento de onda menor situa-se em $249 \mathrm{~nm}$ quando 0 solvente é n-hexano e praticamente não se desloca em metanol 


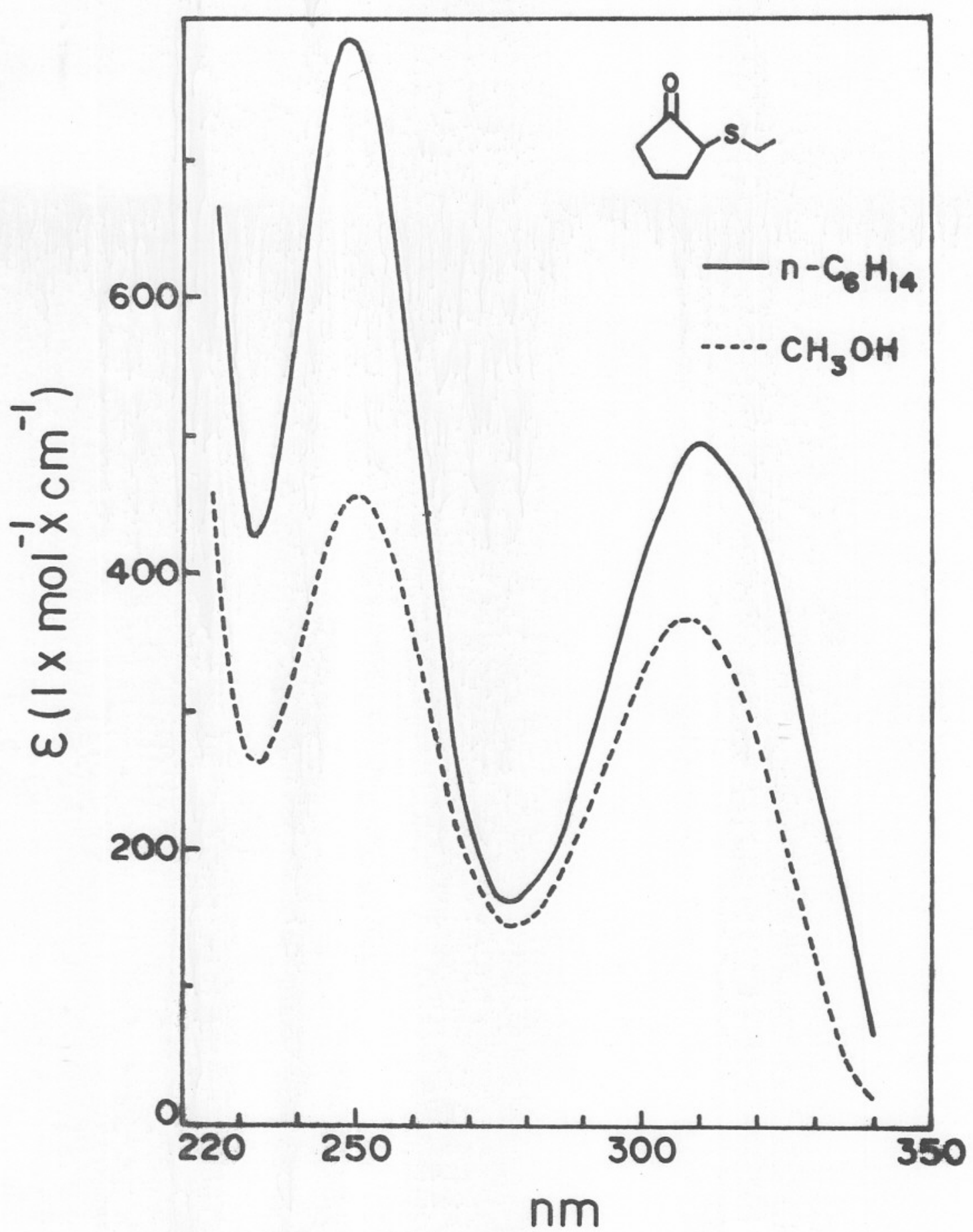

Fig. 13 - Espectros no ultravioleta da 2-etiltiociclopentanona $(X L)$ em $n$-hexano e metanol. 


$$
\begin{aligned}
& \text { BIBLIOTECA } \\
& \text { WNSTIUUTO DE QUIMICA } \\
& \text { Maversidado do São Paulo }
\end{aligned}
$$

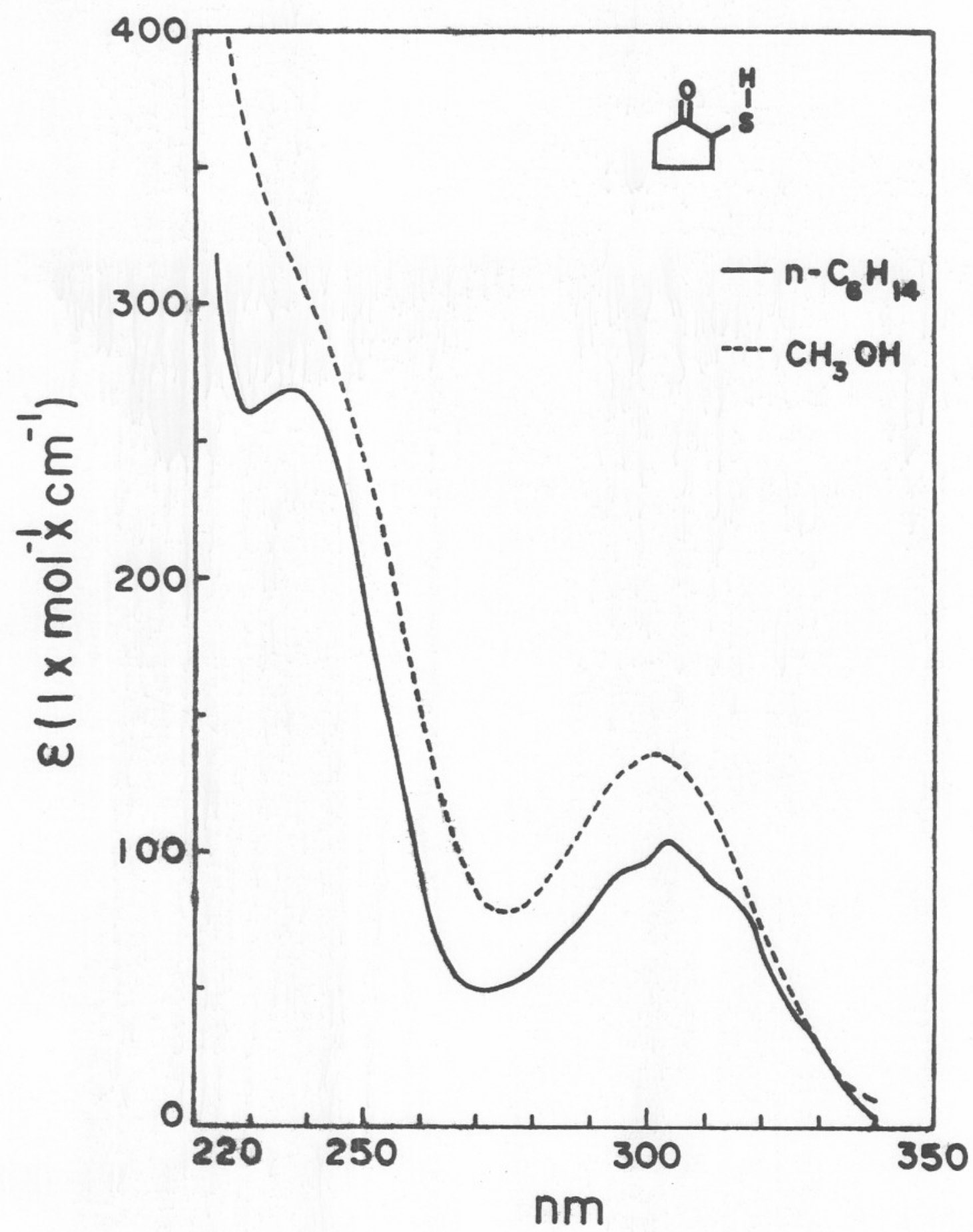

Fig. 14 - Espectros no ultravioleta da 2-mercaptociclopentanona (XLI) em n-hexano e metanol. 
$(250 \mathrm{~nm})$. Entretanto, observa-se um acentuado efeito hipocrōmico ao passar de $n$-hexano $\left(\varepsilon_{249}=787\right)$ para o solvente polar $\left.\varepsilon_{250}=455\right)$.

A 2-mercaptociclopentanona (XLI) apresenta caracteristicas espectrais bastante distintas do composto ( $X L$ ). A banda de absorção centrada em $304 \mathrm{~nm}$ ( $n$-hexano) mostra um contorno vibracional bem definido e a sua intensidade $\left(\varepsilon_{304}=104\right)$ è acen tuadamente menor do que a da banda correspondente na 2-etiltiociclopentanona $(X L) \quad\left(\varepsilon_{310}=495\right)$. Em metanol a banda se desloca para $301 \mathrm{~nm}$ e um pequeno efeito hipercrômico è observado $(\varepsilon=135)$. A banda de absorção em comprimento de onda menor aparece, em n-hexano, a $237 \mathrm{~nm}(\varepsilon=268)$, porēm em metanol apenas se observa uma inflexão na mesma região, o que poderia ser explicado ou por um deslocamento hipsocrômico pronunciado da banda considerada, ou então, resultado de um deslocamento para comprimento de onda maior de uma banda de absorção existente no ultravioleta mais afastado.

Um fato digno de nota é o espectro noultravioleta da 2-mercaptociclopentanona (XLI) em uma solução $10^{-3} \mathrm{M}$ de $\mathrm{KOH}$ em me tanol (fig. 15). Observa-se uma banda em $313 \mathrm{~nm}(\varepsilon=1264$ ) e um ombro em $255 \mathrm{~nm}(\varepsilon=939)$.

A fim de melhor compreender as conformações do anel da ciclopentanona, decidimos preparar a 3-metiltio-1,7,7-trimetilbiciclo [2.2.1] heptanona-2 (XLII), composto não descrito na literatura, que è um derivado da cânfora e, portanto, um compos to modelo da ciclopentanona planar devido a sua geometria rígida do agrupamento $\mathrm{R}-\mathrm{C}-\mathrm{C}=0^{51}$. O composto (XLII) foi obtido pela reação de sulfenilação ${ }^{44}$ do enolato de 1 îtio da (+)-cânfora com dissulfeto de dimetila. 0 espectro de rmp apresentou um duplete $(J=5 \mathrm{~Hz})$ em $\delta=3,09$ correspondente ao próton ligado ao carbono 
46.

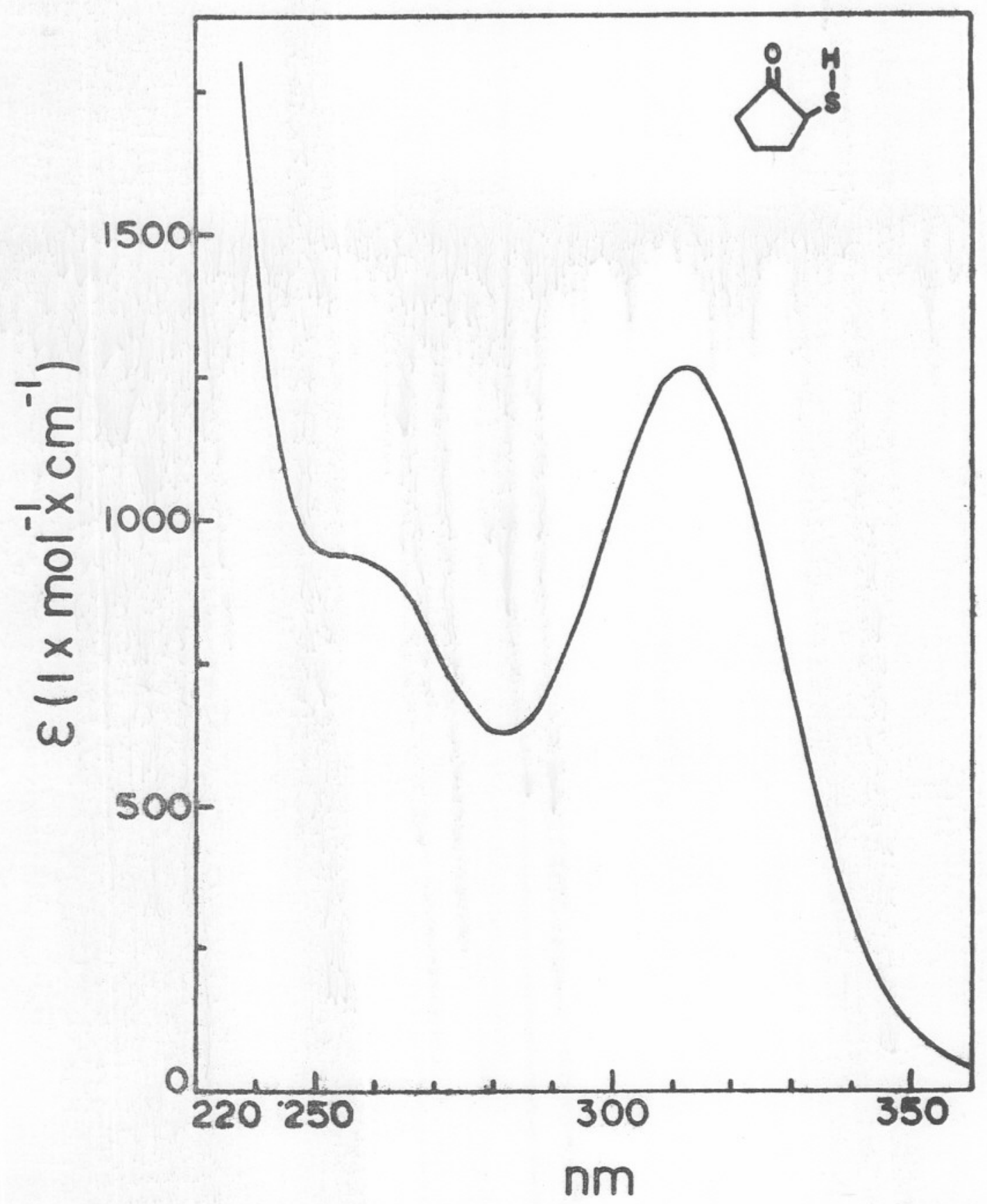

Fig. 15 - Espectro no ultravioleta da 2-mercaptociclopentanona (XLI) em solução $10^{-3} \mathrm{M}$ de $\mathrm{KOH}$ em metanol. 
3 de (XLII), o que nos permitiu concluir que o grupo metiltio es taria na posição endo 54,55 .

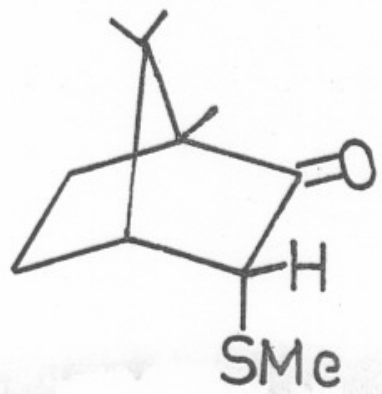

XL I I

Os espectros no ultravioleta de (XLII), em n-hexano e metanol, estão na fig. 16. A banda de absorção em comprimento de onda maior encontra-se centrada em $315 \mathrm{~nm}$ ( $n$-hexano) e se des loca para $310 \mathrm{~nm}$ em metanol. As intensidades $(\varepsilon)$ observadas são, respectivamente, 152 e 134. Em comprimento de onda menor uma se gunda banda è observada em $245 \mathrm{~nm}(\varepsilon=203$, n-hexano) deslocada pa ra $247 \mathrm{~nm}(\varepsilon=195)$ em metanol.

\subsection{DISCUSSATO}

Os dados dos espectros no ultravioleta das cetonas $\alpha$-alquiltio-substituidas, estudadas no presente trabalho, bem como aqueles das cetonas não-substituỉdas correspondentes, estão reunidos na Tabela 1. Na Tabela 2 foram reproduzidos os dados espectrais de outras cetonas contendo um àtomo de enxofre em posição a em relação ao grupo carbonila, descritos na litera tura, com a finalidade de permitir uma discussão mais ampla sobre a interação entre o enxofre e o grupo carbonila e as suas consequências sobre os espectros eletrônicos. 


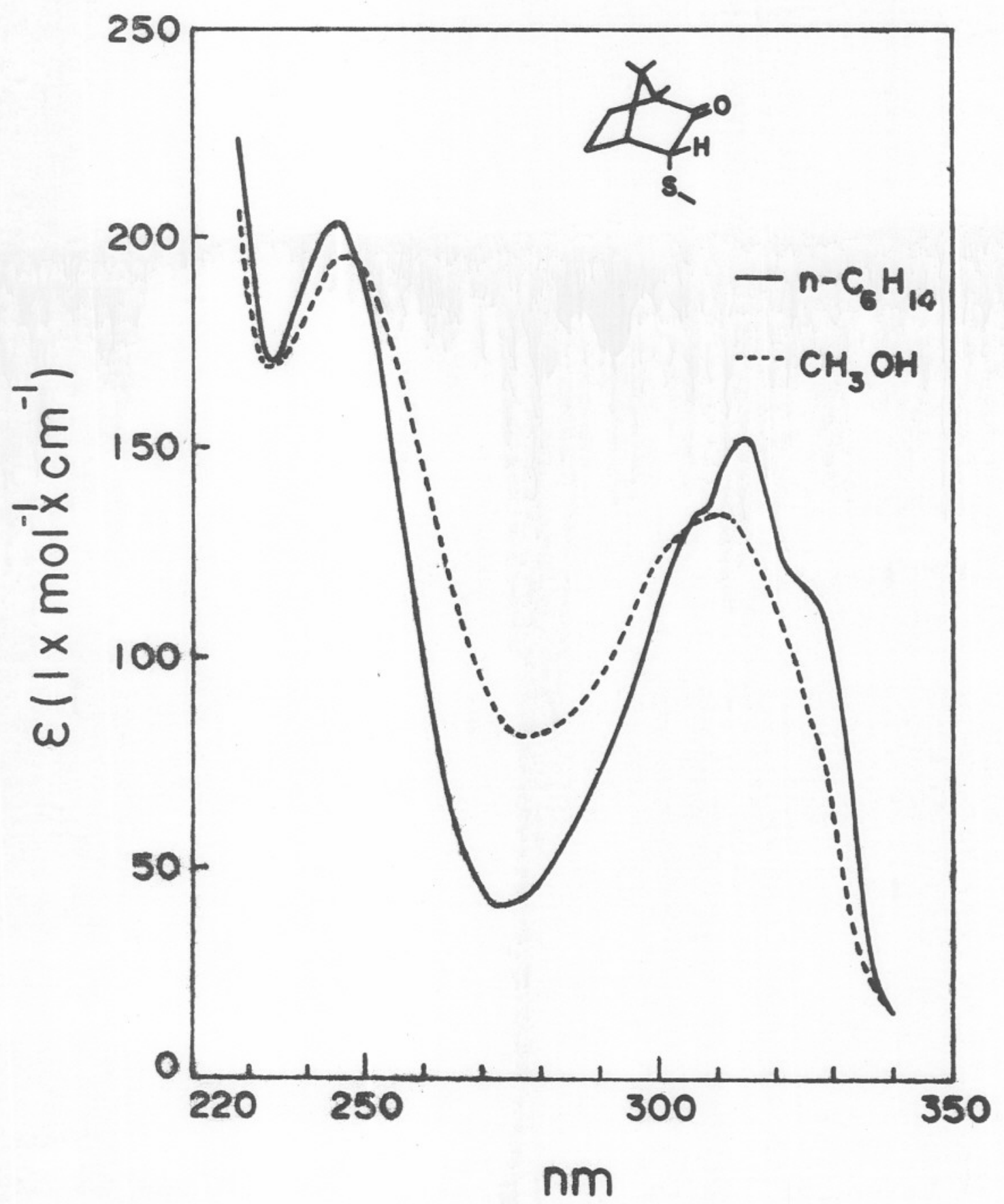

Fig. 16 - Espectros no ultravioleta da 3-metiltio-1,7,7-trimetilbiciclo [2.2.1] heptanona-2 (XLII) em n-hexano e metanol. 
TABELA 1

ESPECTROS NO ULTRAVIOLETA DAS CETONAS ESTUDADAS

\begin{tabular}{|c|c|c|c|}
\hline No & COMPOSTOS & $\begin{array}{l}n-\mathrm{C}_{6} \mathrm{H}_{14} \\
\mathrm{~nm}(\varepsilon)^{\mathrm{a}}\end{array}$ & $\begin{array}{l}\mathrm{CH}_{3} \mathrm{OH} \\
\mathrm{nm}(\varepsilon)^{\mathrm{a}}\end{array}$ \\
\hline (1) & Ciclopentanonab & $300(18)^{c}$ & $287(18)$ \\
\hline \multirow[t]{2}{*}{ (2) } & 2-Etiltiociclopentanona $(X L)$ & $310(495)$ & $308(365)$ \\
\hline & & $249(787)$ & $250(455)$ \\
\hline \multirow[t]{4}{*}{ (3) } & 2-Mercaptociclopentanona (XLI) & $304(104)$ & $301(135)$ \\
\hline & & $237(268)$ & $237(312)^{d}$ \\
\hline & & - & $313(1264)^{e}$ \\
\hline & & - & $255(939)^{e}$ \\
\hline (4) & Cânfora & $291(25)$ & $288(33)$ \\
\hline \multirow[t]{2}{*}{ (5) } & 3-Metiltio-1,7,7-trimeti1- & $315(152)$ & $310(134)$ \\
\hline & biciclo[2.2.1] heptanona-2(XLII) & $245(203)$ & $247(195)$ \\
\hline (6) & Ciclohexanona ${ }^{b}$ & $291(15)^{c}$ & $282(15)$ \\
\hline \multirow[t]{2}{*}{ (7) } & 2-Metiltiociclohexanona ( $X X I X)$ & $307(236)$ & $305(241)$ \\
\hline & & $248(335)$ & $248(262)$ \\
\hline \multirow[t]{2}{*}{ (8) } & 2-Etiltiocicloheianona $(x x x)$ & $309(256)$ & $306(286)$ \\
\hline & & $248(321)$ & $250(282)$ \\
\hline \multirow[t]{2}{*}{ (9) } & $2-t-B u t i l$ tiociclohexanona $(X X X I)$ & $307(222)$ & $303(292)$ \\
\hline & & $242(405)$ & $244(405)$ \\
\hline \multirow[t]{2}{*}{ (10) } & 2-Etiltio-2-metilciclo- & $307(245)$ & $305(362)$ \\
\hline & hexanona (XXXII) & $249(307)$ & $252(330)$ \\
\hline (11) & $4-t-B u t i l c i c l o h e x a n o n a$ & $290(16)$ & $281(18)$ \\
\hline \multirow[t]{2}{*}{ (12) } & 2-Metiltio-4-t-butilciclo- & $308(247)$ & $305(320)$ \\
\hline & hexanona (XXXIII) & $242(353)$ & $242(357)$ \\
\hline \multirow[t]{2}{*}{ (13) } & 2-Etiltio-4-t-butilciclo- & $308(280)$ & $305(320)$ \\
\hline & hexanona (XXXIV) & $248(324)$ & $249(298)$ \\
\hline \multirow[t]{2}{*}{ (14) } & trans-0ctahidro-4a-metil- & & \\
\hline & $-2(1 H)-$ naftalenona & $288(16)$ & $281(21)$ \\
\hline \multirow[t]{2}{*}{ (15) } & Octahidro-4a-meti1-3- & $304(170)$ & $301(149)$ \\
\hline & -metiltio-2(1H)-naftalenona (XXXVII) & $246(284)$ & $244(255)$ \\
\hline \multirow[t]{2}{*}{ (16) } & octahidro-4a-metil-3- & $304(286)$ & $302(237)$ \\
\hline & -etiltio-2(IH)-naftalenona ( $X X X Y I I I)$ & $244(377)$ & $241(332)$ \\
\hline
\end{tabular}


TABELA 2

ESPECTROS NO ULTRAVIOLETA DE ALGUMAS CETONAS $\alpha$-ALQUILTIOSUBSTITUIDAS DESCRITOS NA LITERATURA

\begin{tabular}{|c|c|c|c|}
\hline Ny & COMPOSTOS & $\mathrm{nm}(\varepsilon)^{\mathrm{a}}$ & SOLVENTE \\
\hline \multirow[t]{4}{*}{ (17) } & 4-Tiapentanona $-2(X X V I I)^{b}$ & $301(218)$ & $n-\mathrm{C}_{6} \mathrm{H}_{14}$ \\
\hline & & $242(373)$ & \\
\hline & & $295(289)$ & $50 \%(\mathrm{~V} / \mathrm{V}) \mathrm{EtOH} / \mathrm{H}_{2} \mathrm{O}$ \\
\hline & & $243(328)$ & \\
\hline \multirow[t]{4}{*}{ (18) } & 4-Tiahexanona-2(XVII) $)^{c}$ & $301(224)$ & $n-\mathrm{C}_{6} \mathrm{H}_{14}$ \\
\hline & & $243(457)$ & \\
\hline & & $297(229)$ & $95 \% \mathrm{EtOH}$ \\
\hline & & $244(331)$ & \\
\hline \multirow[t]{2}{*}{ (19) } & $5,5-D i m e t i 1-4-t i a h e x a n o n a-2^{d}$ & $301(155)$ & $n-C_{6} H_{14}$ \\
\hline & & $235(380)$ & \\
\hline \multirow[t]{3}{*}{ (20) } & 2-Metiltiocicloheptanona & $305(270)$ & $\mathrm{C}_{6} \mathrm{H}_{14}$ \\
\hline & & $248(538)$ & \\
\hline & & $216(1780)$ & \\
\hline \multirow[t]{4}{*}{ (21) } & 2-Metiltiociclooctanonae & $306(291)$ & $\mathrm{C}_{6} \mathrm{H}_{14}$ \\
\hline & & $248(710)$ & \\
\hline & & $215(1928)$ & \\
\hline & $\Delta^{8(9)}-1-$ Metiltio-2-p-mentenona ${ }^{e}$ & & \\
\hline \multirow[t]{2}{*}{ (22) } & epimero $z$ & $304(264)$ & $\mathrm{C}_{6} \mathrm{H}_{14}$ \\
\hline & & $249(430)$ & \\
\hline \multirow[t]{2}{*}{ (23) } & epīmero E & $307(242)$ & $\mathrm{C}_{6} \mathrm{H}_{14}$ \\
\hline & & $248(358)$ & \\
\hline \multirow[t]{2}{*}{ (24) } & $9-T i a b i c i c 10[3.3 \cdot 1]$ nonanona $-2^{f}$ & $304(250)$ & $\mathrm{CH}_{3} \mathrm{OH}$ \\
\hline & & $251(300)$ & \\
\hline \multirow[t]{4}{*}{ (25) } & 6-Hidroxi-9-tiabiciclo $[3 \cdot 3 \cdot 1]$ - & $305(106)$ & $\mathrm{C}_{6} \mathrm{H}_{12}$ \\
\hline & nonanona $-2^{g}$ & $242(227)$ & \\
\hline & & $302(190)$ & $\mathrm{CH}_{3} \mathrm{OH}$ \\
\hline & & $246(265)$ & \\
\hline \multirow[t]{2}{*}{ (26) } & 2-Tiaadamantanona $-4(X X V)^{h}$ & $311(269)$ & Dioxano \\
\hline & & $254(324)$ & \\
\hline \multirow[t]{3}{*}{ (27) } & 8(e)-Hidroxi-2-tiaadaman- & $311(257)$ & Dioxano \\
\hline & tanona $-4^{\mathrm{h}}$ & $252(302)$ & \\
\hline & & $211(1560)$ & \\
\hline \multirow[t]{3}{*}{ (28) } & $8(a)-H i d r o x i-2-t i a a d a m a n-$ & $310(99)$ & Dioxano \\
\hline & tanona $-4^{h}$ & $250(140)$ & \\
\hline & & $208(1230)$ & \\
\hline
\end{tabular}


(29)

(31)

\section{(32)} (6S)-6-metiltetrahidrotiopiranona (XXVI) ${ }^{i}$

$$
\text { 3-Tiaciclopentanona }(X I X)^{c}
$$

$300(66)$

$$
247(151)
$$$$
\text { 298(76) }
$$$$
\text { 248(154) }
$$$$
\text { 3-Tiaciclohexanona }(X x)^{c}
$$

$305(166)$

$247(295)$

$305(240)$

$247(295)$

$305(178)$

248(345)

$306(223)$

248(261)

$307(269)$

245(646)

222(1175)

(33) 3-Etilenoditio-5B-colestanona $-4^{j}$

$311(302)$

$246(692)^{k}$

225(1175)

(34) 3-(Etileno-1-oxi-2-tio) $5 \alpha$ colestanona $-4^{j} ; 3 a-5(a \times i a 1)$

(35) ibid, $3 \beta-5$ (equatorial)

$309(309)$.

255(302)

295(100)

$253(178)^{k}$

(36) 3-(Etileno-1-oxi-2-tio)-5B-colestanona $-4^{j} ; 3 \alpha-S$ (equatorial)

(37) ibid, $3 \beta-S(a \times i a l)$

$299(71)$

$250(141)^{k}$

314 (309)

256(275) -continuação-

$$
n-\mathrm{C}_{6} \mathrm{H}_{14}
$$

95\% EtOH

$$
n-\mathrm{C}_{6} \mathrm{H}_{14}
$$

95\% EtOH

isooctano

$$
\mathrm{CH}_{3} \mathrm{OH}
$$

$\mathrm{CH}_{3} \mathrm{OH} / \mathrm{OIO}$ ×ano

$(2: 1)$

$\mathrm{CH}_{3} \mathrm{OH} / \mathrm{DiO}$ xano

$\mathrm{CH}_{3} \mathrm{OH} / \mathrm{OIOXanO}$

$\mathrm{CH}_{3} \mathrm{OH} / \mathrm{OIOxano}$

\footnotetext{
${ }^{a} \lambda_{\max }\left(1 \times \mathrm{mol}^{-1} \times \mathrm{cm}^{-1}\right) ;{ }^{b}$ ref.40; ${ }^{c}$ ref. 39; ${ }^{d}$ ref.36; ${ }^{\mathrm{e}}$ ref.56; ${ }^{f}$ ref.57;

$g_{\text {ref. } 58 ; h_{\text {ref. 37; }} i_{\text {ref. } 38 ;} j_{\text {ref. } 59 ;} \text { ombro. }}$
} 
Uma anāilise dos comprimentos de onda e das intensidạ des das bandas de absorção, bem como do efeito de solvente sobre as mesmas (Tab. 1), sugere que a banda em comprimento de on da maior pode ser atribuĩda a uma transição $n \rightarrow \pi *$ do grupo car bonila e a de comprimento de onda menor à transições envolvendo - par solitārio de elētrons do enxofre, provavelmente uma transição $n \rightarrow \sigma^{*} 38,42$. Uma interpretação diferente para a banda em comprimento de onda menor foi dada por Hudec ${ }^{27}$ que, baseado em cálculos de Levin et al. ${ }^{23}$, a atribuiu a uma segunda transição $n \rightarrow \pi^{*}$.

Ambas as bandas apresentam deslocamentos batocrōmicos quando comparadas com as transições observadas nas cetonas e tioēteres correspondentes não substituīdos. Assim, as transições $n \rightarrow \pi^{*}$ do grupo carbonila em cetonas não substituỉdas normalmente são observadas nà região de $290 \mathrm{~nm}^{4}$ e as transições $n \rightarrow \sigma^{*}$ de tioēteres acīclicos na região de $200-230 \mathrm{~nm}$, enquanto que nos cíclicos um deslocamento batocrômico é observado dependendo do àngulo $C-S-C$, sendo maior a medida em que o tamanho do anel diminui 60 .

Comparando os compostos (7) - (10) da Tabela 1, nota-se que as bandas de absorção correspondentes à transição $\mathrm{n} \rightarrow \pi^{*}$ do grupo carbonila, encontram-se em cerca de $307 \mathrm{~nm}$ em n-hexano e são deslocadas para $305 \mathrm{~nm}$ em metanol, isto ē, um di $\underline{s}$ creto deslocamento hipsocrômico é observado sendo maior no caso da 2-t-butiltiociclohexanona (9). A mudança de solvente apolar para polar prōtico tem como consequéncia um efeito hipercrômico, reduzido na 2-metiltiociclohexanona (7) e acentuado na 2-etiltio-2-metilciclohexanona (10), notando-se um aumento progressivo do composto (7) ao (10). Uma possivel causa de tal aumento de intensidade poderia ser uma maior estabilização de um dos con- 
fôrmeros do anel do ciclohexano, o que favoreceria a interação entre o enxofre e o grupo carbonila. Tal sugestão, entretanto, fica excluida, pois tanto a 2-metiltio-como a 2-etiltio-4-t-bu tilciclohexanona (compostos (11) e (12), Tab. 1), que são constituĩdas de misturas diastereomēricas em que a conformação do anel do ciclohexano è rígida, apresentam um efeito hipercrômico semethante.

Nos compostos (7) - (13) o grupo alquiltio ocupa preferencialmente a posição axial, conforme foi descrito em 2.2 . para a 2-metiltiociclohexanona (XXIX, (7) Tab.1) e 2-metiltio4-t-butilciclohexanona (XXXIII, (12) Tab. 1). Tal fato foi confirmado nos epimeros $Z$ e $E$ da $\Delta^{8(a)}-1$-metiltio-2-p-mentenona (compostos (22) e (23), Tab. 2) em que 99 e $70 \%$, respectivamente, da mistura de confōrmeros são aqueles com o grupo metiltio em posição axial ${ }^{56}$. Os espectros no ultravioleta desses compostos, em $n$-hexano, apresentam as mesmas bandas de absorção em com primentos de onda e de intensidades comparāveis aos compostos por nōs estudados.

$\mathrm{Na}$ 2-tiaadamantanona-4 (26, Tab. 2), um composto tri cỉclico de estrutura rỉgida em que os anēis de seis membros pos suem conformações cadeira, o enxofre em posição a em relação ao grupo carbonila encontra-se em posição axial. 0 espectro no ultravioleta de (26), em dioxano, apresenta duas bandas de absorção, uma em $311 \mathrm{~nm}(\varepsilon=269)$ e outra em $254 \mathrm{~nm}(\varepsilon=324)^{37}$. Devido a sua rigidez (26) pode ser considerado como composto modelo de uma ciclohexanona $\alpha$-alquiltio-substituida axialmente, e o seu espectro eletrōnico foi analisado por Snatzke e Wolfram ${ }^{37}$ cons derando as regras (i) - (iv) de Hudec 21 (pag. 7).

Tendo em vista o fato das regras de Hudec preveremas modificações do espectro no ultravioleta ao passar da adamanta- 
nona para a 2-tiaadamantanona-4 (26), cetonas com grupos $\alpha-a 1-$ quiltio em posição equatorial deveriam apresentar espectros no ultravioleta com características diferentes das acima descritas. Considerando os espectros dos compostos (15) e (16) da Tabela 1. ambos contendo o diastereômero com o grupo alquiltio equatorial em maior porcentagem, 75 e $64 \%$, respectivamente, observa-se que apresentam duas bandas de absorção. A de comprimento de onda maior correspondente à transição $n \rightarrow \pi^{*}$, encontra-se em $304 \mathrm{~nm}(n-h e x a n o)$ e em $301 \mathrm{~nm}$ (metanol). Ao comparares tes valores com os da trans-octahidro-4a-metil-2(1H)-naftalenona (composto 14, Tab. 1) nos mesmos solventes, nota-se que as bandas sofreram um deslocamento batocrômico de 16 e $20 \mathrm{~nm}$, respectivamente, contrariamente ao esperado pela regra (i) de $\mathrm{Hu}-$ $\operatorname{dec}^{21}$ (pag. 7). Os valores de $\varepsilon$ em $n$-hexano são 170 e 286 , respectivamente para (15) e (16), ou seja, a intensidade da banda $n \rightarrow \pi^{*}$ diminui sensivelmente na octahidro-4a-metil-3-metiltio-2 (1H) -naftalenona (15) quando oomparada com as dos compostos (7)(10), (12) e (13) da Tabela 1, porēm na octahidro-4a-metil-3etiltio-2(1H)-naftalenona (16) o valor de $\varepsilon \bar{e}$ maior do que a mé dia dos valores observados nos mesmos compostos.

Dois aspectos precisam ser considerados nos espectros eletrônicos em metanol dos compostos até aqui considerados, a saber: (a) - Os derivados da ciclohexanona $(7-10$, Tab.1) e 4-t-butilciclohexanona (12 e 13, Tab.1) apresentam um efeito hi percrómico na banda $n \longrightarrow \pi^{*}$ do grupo carbonila ao se comparar os valores de $\varepsilon$ com aqueles determinados em $n$-hexano. Nos compostos (15) e (16), entretanto, um efeito hipocrōmico è observado nas mesmas condições. (b) - Um segundo ponto a ressaltar refere-se a banda de absorção em comprimento de onda menor, provavelmente envolvendo o par solitārio de elétrons do enxofre. Nos 
derivados (15) e (16) da trans-octahidro-4a-metil-2(1H)-naftale nona, a banda de absorção em cerca de $245 \mathrm{~nm}$ apresenta um deslo camento hipsocrômico ao passar de n-hexano para o metanol, enquanto que, nos compostos (7) - (10), (12) e (13) um deslocamento batocrómico é observado. Estes fatos experimentais sugerem que os diferentes fatores responsāveis pela interação entre on xofre e o grupo carbonila, agem com diferente intensidade ao se mudar as conformações moleculares.

Robinson et az. ${ }^{59}$ estudaram as propriedades quirópti cas de 3 -etileno-mono- e ditiocetais das $5 \alpha$-e $5 \beta$-colestanonas4 (compostos 32 a 37 , Tab. 2) e os seus resultados confirmam as nossas observações. Merecem uma anālise mais detalhada os 3-(eti leno-1-oxi-2-tio) derivados em que o enxofre pode ocupar tanto uma posição equatorial como uma axial. Assim, nos compostos (34) e (37) da Tabela 2 em que o enxofre se encontra emposição axial, os espectros no ultravioleta apresentam duas bandas de absorção na região de 310 e $255 \mathrm{~nm}$, respectivamente, cujas intensidades ( $\varepsilon$ ) são comparāveis às dos compostos (7) - (10), (12) e (13) da Tabela 1 e a banda $n \rightarrow \pi^{*}$ do grupo carbonila está deslocada batocromicamente em relação a da 4-colestanona não substituĩda. De outro lado, nos espectros eletrōnicos dos compostos (35) e (36) da Tabela 2 , em que o enxofre ocupa uma posição equatorial, ap sar de tambēm apresentarem duas bandas de absorção, nota-se uma redução na intensidade das mesmas e o deslocamento batocrômico em relação à banda $n \rightarrow \pi^{*}$ do 4-colestanona é menor do que aquele observado em (34) e (37). Pelos dados de dicroismo circular, Robinson et al. sugeriram que um dos orbitais $n$ do enxofreaxial se superpõe dissimetricamente com os orbitais $n$ e $\pi^{*}$ do grupo carbonila, enquanto que o orbital $n$ ou então $\pi$ do ūitimo não se superpõe com o orbital excitado do ātomo de enxofre que, prova- 
velmente, possui um carāter $\sigma^{*}$.

As cetonas (29) a (31) da Tabela 2 que possuem um en xofre endocíclico, apresentam espectros eletrônicos de características semelhantes às atē aqui discutidas. Observa-se que as intensidades das bandas de absorção são menores do que as dos compostos contendo o enxofre em posição axial.

os resultados expostos parecem indicar que a posição axial do átomo de enxofre, embora importante para a existência de uma interação entre o inesmo e o grupo carbonila, não é essen cial e os seus pares solitārios de elétrons podem interagiratra vēs do espaço ou então atravēs das ligações $\sigma^{22}$ com o grưpo car bonila. Rosenfield e Moscowitz ${ }^{60}$ mostraram que os pares solitários de elētrons do enxofre em tioéteres diferem em energia sen do que o de energia maior estaria essencialmente em um orbital 3p. Parece razoāvel sugerir que seja este par solitārio que interaja preferencialmente com o grupo carbonila.

Segundo Levin et $a Z^{23}$, as interações orbitais em $\alpha$-aminocetonas, em ordem decrescente de importāncia nas proprie dades espectroscōpicas daquelas seria: (1)-Acoplamento através das ligações dos pares solitārios de elétrons do nitrogênio e oxigênio. (2) - Interação atravēs do espaço destes pares solitārios. (3) - Hiperconjugação entre o nīvel $\sigma^{*}$ da ligação $C-N$ e do sistema $\pi$ da carbonila. (4) - Superposição direta do par solitārio do nitrogênio com o sistema $\pi$ da carbonila. Cada uma destas interações apresenta uma dependência conformacional distinta.

Considerando os resultados dos autores 23 , a interação atravēs do espaço do orbital $3 p$ do enxofre e um orbital $p$ do oxigênio do grupo carbonila dependerá acentuadamente do ângulo entre o grupo carbonila e a ligação $C-S$ sendo mais importante quando os mesmos estão eclipsados, isto é, quando o grupo al- 
quiltio ocupar uma posição equatorial. Alēm deste fator, o orbi tal $3 p$ do enxofre deverá ficar paralelo ao orbital o da ligação $C_{C=0}-C_{\alpha}$. Esta condição dependerā das conformações ao longo da ligação $C-S$.

0 acoplamento entre o par solitārio do enxofre e um do oxigênio atravēs das ligações, envolvendo os nĩveis $\sigma$ e $\sigma^{*}$ da ligação $C_{C=0}-C_{\alpha}$ depende essencialmente da orientação do or bital $3 p$ em relação à $C_{C=0}-C_{\alpha}$, sendo máximo quando a superposição dos mesmos for maior, ou seja, quando os dois orbitais f $\underline{j}$ cam paralelos, condição esta dependente da conformação ao longo da 1 igação C - S.

As interações expostas não são as únicas importantes na explicação das propriedades espectroscópicas dos compostos es tudados. Assim, a interação dos orbitais da ligação C - S com 0 sistema $\pi$ da carbonila alterarā o nỉvel $\pi *^{18,23}$, quando o grupo alquiltio estiver em posição axial. Uma outra variāvel a ser con siderada é o ângulo $C_{C=0}-C_{\alpha}$ - S pois conforme mostraram Levin et al. ${ }^{23}$, variações no mesmo alterarão os nîveis energéticos dos orbitais dos pares solitārios dos heteroātomos.

Os espectros no ultravioleta da 2-etiltiociclopentanona $[(2)$, Tabela I], apresentam bandas de absorção semelhantes às dos derivados alquiltio-substituídos de seis membros, porém as intensidades das mesmas são maiores, especialmente em $n$-hexano. Uma diferença fundamental, entretanto, entre os derivados cícli cos de cinco e de seis membros, è o acentuado efeito hipocrômico observado nos primeiros ao passar do solvente apolar aopolar prōtico. Nas a-alquiltiociclohexanonas tal mudança de solvente tem como consequência um reduzido efeito hipercrômico na banda de maior comprimento de onda e hipocrômico na de comprimento de onda menor. Conforme foi descrito em 2.2., a 2-etiltiociclopen- 
tanona é constituīda por cerca de $80 \%$ do conförmero com o grupo etiltio em posição quasi-axial e parece razoāvel sugerir que as diferenças espectrais entre os derivados das ciclopentanona ec $\underline{i}$ clohexanona sejam devidas às diferentes conformações do grupo alquiltio. No caso da ciclohexanona, o enxofre em posição perfeitamente axial forma um ângulo de $120^{\circ} \mathrm{com}$ a ligação $\sigma$ do grụ po carbonila, enquanto que na ciclopentanona o ângulo entre 0 enxofre quasi-axial e o grupo carbonila seria próximo a $90^{\circ}$, p $\underline{0}$ rēm a explicação não parece ser simples.

os espectros no ultravioleta da 3-metiltio-1,7,7-tri metil-biciclo [2.2.7] -heptanona-2 [(5), Tab. 1] permitem uma me lhor anālise daqueles da 2-etiltiociclopentanona e os efeitos conformacionais neles observado. 0 composto (5) è um modelo da ciclopentanona planar (2.2., pag. 45) com o grupo metiltio e o grupo carbonila formando um ângulo projetado de aproximadamente $60^{\circ} 51$. Devido à estrutura da molécula o grupo metiltio parece ficar conformacionalmente mais restrito. Além disto o ātomo de enxofre ocupa uma posição intermediāria entre as posições axial e equatorial. A primeira, pelos resultados do presente trabalho e os descritos na literatura, parece ser mais favorāvel a uma interação atravēs das ligações entre o enxofre e o grupo carbo nila, enquanto a segunda seria mais favorāvel a uma interação atravēs do espaço entre os pares solitārios do enxofre e do oxi gênio. As interações atravēs do espaço e atravēs das ligações não se excluem mutuamente, sendo a sua participação relativa uma função das conformações moleculares.

Os resultados apresentados permitem concluir que a interação entre o enxofre e o grupo carbonila e as suas consequências sobre os espectros no ultravioleta das cetonas $\alpha-a l-$ quiltio-substituidas dependem essencialmente de dois fatores con 
formacionais: (a) - A orientação do grupo alquiltio em relaçao ao grupo carbonila sendo as posições quasi-axial e axial as mais favoráveis. (b) - As conformações do grupo alquiltio em relação a ligação $C_{C=0}-C_{\alpha}$ A medida em que a superposição do orbital $3 p$ do enxofre com a ligação o se torna menos efetiva, menores serão as intensidades e os deslocamentos batocrômicos das bandas de absorção.

Estas conclusões podem ser confirmadas pela anālise dos espectros no ultravioleta da 2 -mercaptociclopentanona $[(3)$, Tab. 1] que é constituỉda de cerca de $50 \%$ do confôrmero associa do intramolecularmente e $50 \%$ de um conförmero em que o grupo $\mathrm{S}-\mathrm{H}$ não associado estaria mais prōximo de uma conformação equatoriaz do que axial (2.2., pag. 42). Em n-hexano observa-se um deslocá mento batocrômico relativamente pequeno da banda $n \rightarrow \pi^{*}$, de intensidade reduzida, do grupo carbonila em relação a da ciclopen tanona não substituỉda. Estes resultados são comparāveis aos dos compostos (35) e (36) da Tabela 2, em que o enxofre ocupa uma po sição equatorial. Alëm disto, $\bar{e}$ interessante notar que tanto no composto (3) como em (35) e (36) o enxofre, devido ao fato de participar de um sistema cỉclico, apresenta restrições conforma cionais e provavelmente por causa disto a interação do par sol tārio do enxofre com o grupo carbonila seja dificultada. A banda em comprimento de onda menor da 2-mercaptociclopentanona também aparece deslocada para o azul em relação às mesmas bandas de a $\underline{b}$ sorção das cetonas $\alpha$-alquiltio-substituỉdas, o que sugere que as duas bandas estão correlacionadas ${ }^{36}$.

Uma possīvel confirmação dos fatores importantes, pạ ra que exista uma interação pronunciada entre o enxofre e o gru po carbonila, parece ser o espectro no ultravioleta da 2-mercap tociclopentanona em meio alcalino $[(3), T a b . l]$. As duas bandas 
de absorção observadas em 313 e $255 \mathrm{~nm}$, respectivamente, são de intensidade elevada, o que estā de acordo com o fato de não mais existir a ponte de hidrogênio intramolecular no composto. Isto permite ao enxofre ocupar uma posição quasi-axial e de outro la do, por não possuir nenhum substituinte, não haverā restrições quanto as diferentes orientação dos orbitais $3 p$ que contém os pa res eTetrônicos. Nas Figuras 17 e 18 são apresentados os espectros no ultravioleta de (2), (3) e (5) em $n$-hexano e metanol, respectivamente, a fim de permitir uma melhor comparaçãodos mes mos.

Os resultados deste trabalho e aqueles descritos na literatura (1.2.2., pag. 15) sugerem que, apesar de um nümero muito grande de evidências experimentais, a interação entre o en xofre e o grupo carbonila ainda está longe de ser compreendida. Em nossa opinião, somente cálculos teöricos poderão esclarecer ou então sugerir novas experiências que nos possam levar a uma compreensão melhor das interaçọes existentes e porque não,da na tureza da ligação quỉmica. 


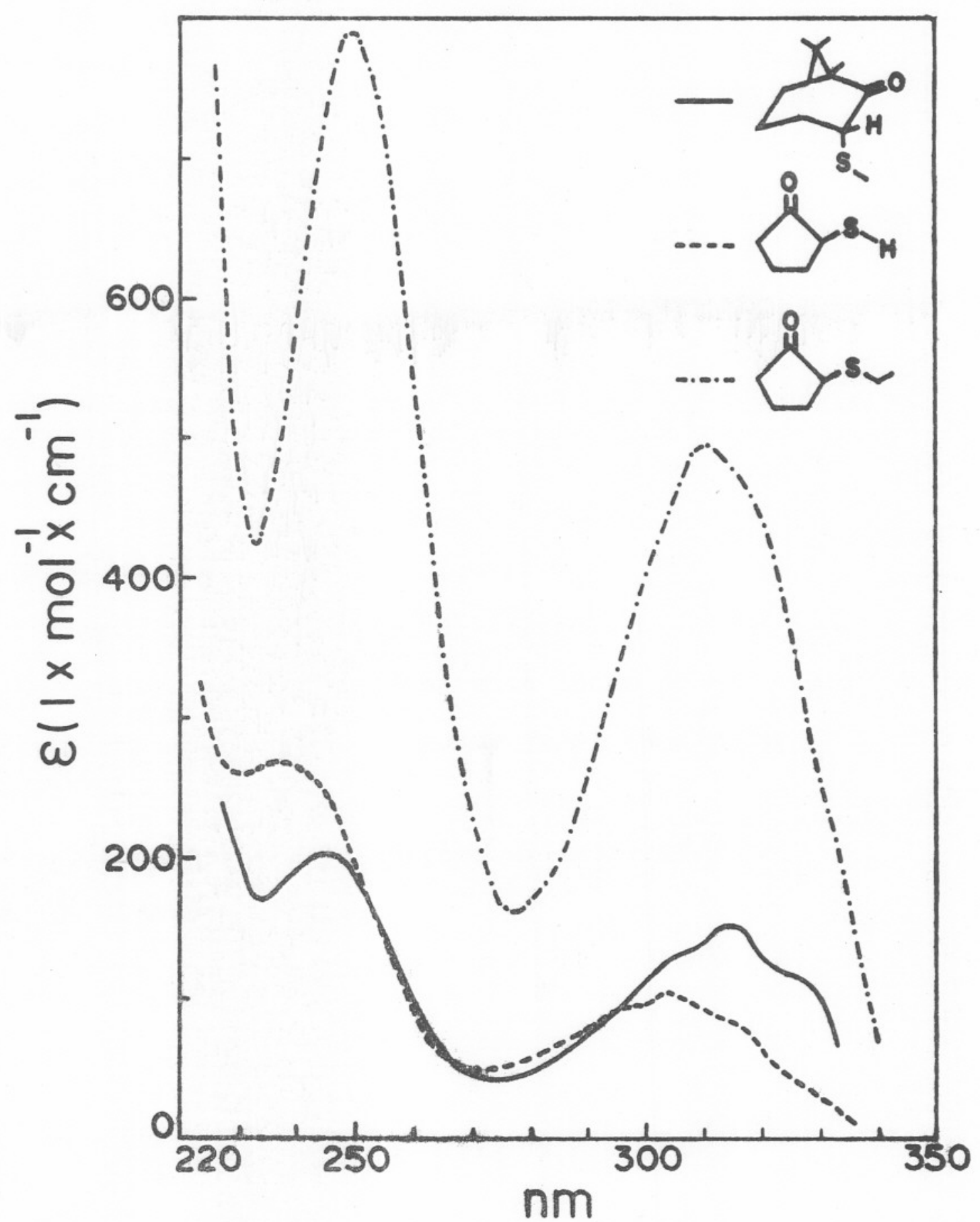

Fig. 17 - Espectros no ultravioleta, em n-hexano, de: 2-mercaptociclopentanona (XLI), 2-etiltiociclopentanona (XL) e 3-metiltio-1,7,7-trimetilbiciclo [2.2.1] heptanona2 (XLII). 
62.

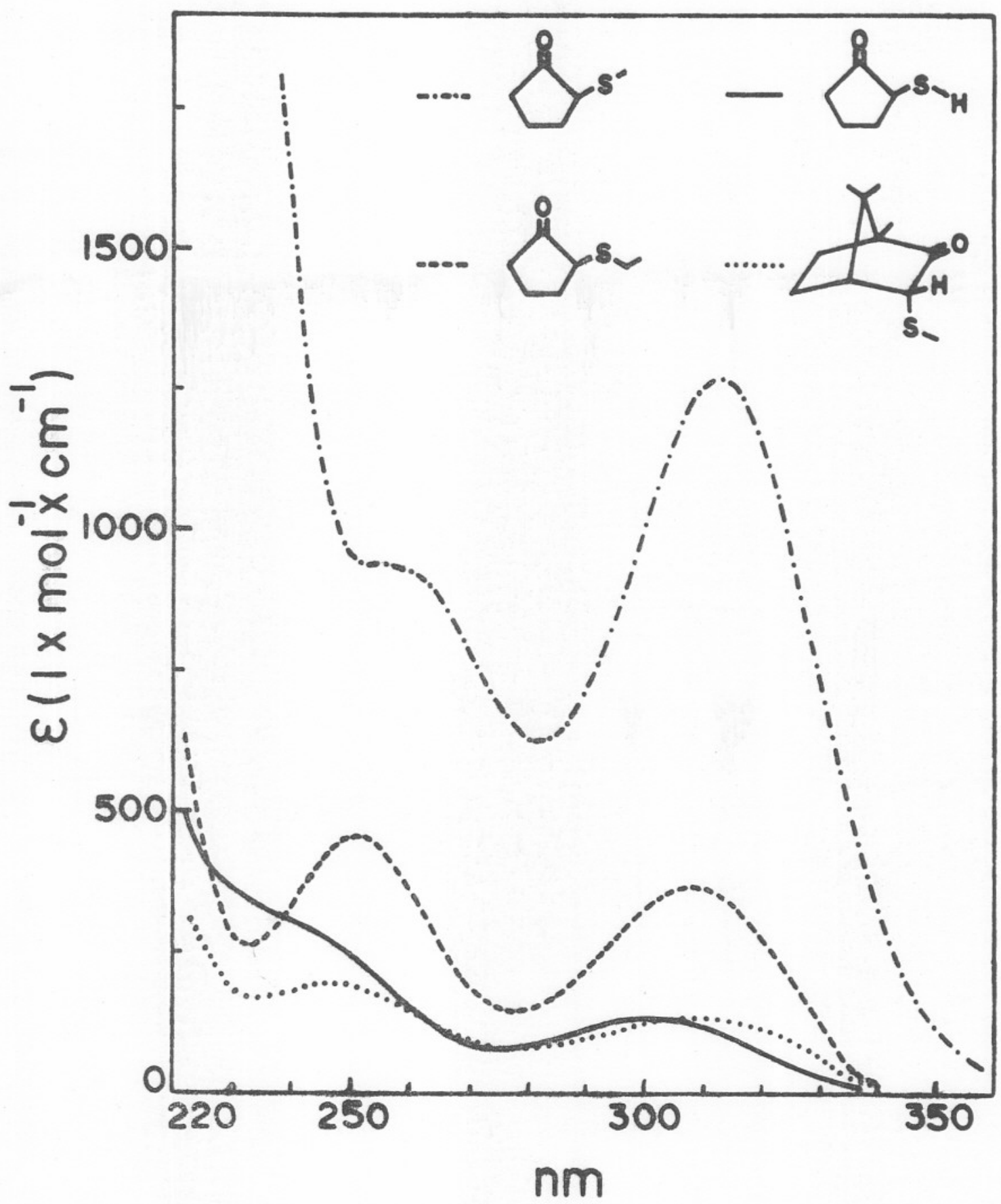

Fig. 18 - Espectros no ultravioleta, (a) em metanol de: ( $\longrightarrow$ ) 2-mercaptociclopentanona (XLI), 2-etiltiociclopenta nona $(X L)$ e 3-metiltio-1,7,7-trimetilbiciclo [2.2.7] heptanona-2 (XLII); (b) em solução $10^{-3} \mathrm{M}$ de $\mathrm{KOH}$ em metanol da (-.-) 2-mercaptociclopentanona (XLI). 


\section{PARTE EXPER IMENTAL}

\section{1. INSTRUMENTOS, MEDIDAS ESPECTROSCOPICAS E ANALISES}

Os espectros no ultravioleta foram registrados em um espectrofotōmetro Beckman, modelo DK-2A, utilizando celas calibradas de quartzo de $1,00 \mathrm{~cm}$ de espessura. 0 s solventes emprega dos foram n-hexano e metanol absolutos. Foram determinados os espectros de pelo menos trēs soluções de concentração diferente $\left(10^{-4}\right.$ a $\left.10^{-2} \mathrm{M}\right)$ para cada substāncia estudada. As absorptividades molares $\left(\varepsilon, 1 \times \mathrm{mol}^{-1} \times \mathrm{cm}^{-1}\right)$ foram calculadas pela regressão linear de minimos quadrados a partir dos valores de absorbância nos espectros e das respectivas concentrações das soluções empregadas. Todas as medidas foram efetuadas a $25 \pm 1^{\circ} \mathrm{C}$.

os espectros no infravermelho foram obtidos em um es pectrofotōmetro de grade de difração Perkin Elmer 457-A ou 180. Para as medidas em solução utilizaram-se celas pareadas com janelas de cloreto de sódio de $0,5 \mathrm{~mm}$ de espessura e, para os espectros em filme, pastilhas de cloreto de sōdio. As frequências de estiramento do grupo carbonila $\left(\nu_{\mathrm{CO}}\right)$ foram determinadas em soluções de tetracloreto de carbono e de cloroförmio, cuja fai$x a$ de concentração variava de 2 a $5 \times 10^{-2} \mathrm{M}$. Como referéncia foi utilizada a frequência de $1603,08 \mathrm{~cm}^{-1}$ do filme de poliestireno. Um espectrômetro Varian T-60 operando com uma fonte de radiofrequência de $60 \mathrm{MHz}$ e um aparelho Varian XL-100 de 100 MHz foram utilizados para a determinação dosespectros de ressonância magnētica protōnica (rmp) e de ${ }^{13} \mathrm{C}$. Nos espectros de rmp, os deslocamentos quỉmicos $(\delta)$ são relatados em partes por milhão em relação ao tetrametilsilano (TMS), utilizado como padrão in- 
terno, colocando entre parēnteses o nümero de hidrogênios, a mu l tiplicidade (s-singlete, d-duplete, t-triplete, q-quarteto,m-mu? tiplete) e a constante de acoplamento (J) em Hz. Os solventes empregados foram tetracloreto de carbono e deutero clorofórmio. As anālises cromatogrāficas lĩquido-gās foram efetuạ das em um instrumento Varian, modelo 1868-40, equipado com um integrador digital eletrônico, utilizando o detector de ionização de chama. O gās de arraste era nitrogênio e as colunas de $3,18 \mathrm{~mm} \times 1,52 \mathrm{~m}$ eram: 10\% FFAP sobre Chromosorb W, 60/80 mesh e $5 \%$ QF-1 sobre Chromosorb W, 60/80 mesh. As anālises cromatogrāficas foram efetuadas isotermicamente e a temperatura empregada é indicada em cada caso.

As cromatografias em coluna foram realizadas utilizando-se sîlica gel "Kiesel-gel 60, 0,063-0, 200 mm, MerckA.G.".

As anālises elementares foram efetuadas nos laboratō rios da Rhodia Indústrias Quỉmicas e Têxteis S.A., Paulīnia, SP, sob a direção do Dr. Marino T,Fabi.

\subsection{COMPOSTOS}

\subsubsection{Solventes}

Nas medidas espectroscōpicas foram utilizados tetracloreto de carbono, cloroförmio, n-hexano e metanol absoluto de grau espectromētrico "Uvasol, Merck A.G.". Todos os outros solventes empregados foram purificados por métodos descritos na $1 \underline{i}$ teratura 61 .

\subsubsection{Compostos disponīveis em nosso laboratōrio}

2-Mercaptociclopentanona (XLI) e 2-etiltiociclopentạ nona ( $X L$ ) preparados e purificados pela Sra. I.C.Coelho Calegão ${ }^{52}$. 


\section{3 . Compostos sintetizados}

\subsubsection{2-Etiltiociclohexanona $(X X X)$}

a) 2-Etiltiociclohexanona $(X X X)^{45}$ - A uma solução de etạ notiolato de sódio, obtida a partir de $4,87 \mathrm{~g}(0,21$ mol) de sōdio, $14,5 \mathrm{~g}(0,23 \mathrm{~mol})$ de etanotiol e $100 \mathrm{ml}$ de etanol abs., foram adicionados, gota a gota, 28,1g $(0,21 \mathrm{~mol})$ de 2-clorociclohexanona (Aldrich, redestilada p.e. $81-82^{\circ} \mathrm{C} / 9$ Torr), dissolvidos em $10 \mathrm{ml}$ de etanol abs., sob agitação e resfriamento a $-10^{\circ} \mathrm{C}$. Completada a adição, a temperatura da mistura reacional foi man tida a $25^{\circ} \mathrm{C}$ por duas horas e, em seguida, esta foi jogada em àgua. 0 óleo formado foi extraỉdo em ēter, o extrato etéreo lavado com àgua, solução saturada de cloreto de sōdio e seco com sulfato de magnēsio anidro. O ēter foi removido e o produto des tillado à pressão reduzida fornecendo $29,4 \mathrm{~g}$ de um līquido de p.e. $107-109^{\circ} \mathrm{C} / 7$ Torr (1it. ${ }^{45} \mathrm{p} . e \cdot 115^{\circ} \mathrm{C} / 15$ Torr). A anālise cro matogräfica $\left(5 \% \mathrm{QF}-1,130^{\circ} \mathrm{C}\right)$ revelou a existência de uma impure za (aprox. 20\%) na 2-etiltiociclohexanona, não separāvel por des tilação fracionada. Preparou-se o 6-etiltio-1,4-dioxaspiro 4,5 decano.

b) 6-Etiltio-1,4-dioxaspiro $|4,5|$ decano (XLIII) - Empregou-se o mëtodo descrito por Kuhn 62 Uma mistura de $17,5 \mathrm{~g}$ de 2etiltiociclohexanona, obtida em $a, 7,5 \mathrm{~g}(0,12 \mathrm{~mol})$ de etilenoglicol, $70 \mathrm{ml}$ de benzeno abs. e $0,2 \mathrm{~g}$ de ácido p-toluenosulfōnico, contida em um balão de $125 \mathrm{ml}$ munido de um aparelho DeanStark modificado63, foi aquecida a refluxo até cessar a separação de āgua. Adicionaram-se $20 \mathrm{ml}$ de uma solução metanōlica de $\mathrm{NaOH}$ a $5 \%$, agitou-se durante $30 \mathrm{~min}$. e jogou-se em $30 \mathrm{ml}$ de āgua. Apōs lavagem com āgua e secagem com sulfato de magnésio anidro, 
- benzeno do extrato orgânico foi evaporado e o óleo obtido des tilado à pressão reduzida. Obtiveram-se $18,1 \mathrm{~g}$ de produto de p.e. $97,5-99^{\circ} \mathrm{C} / 3$ Torr, cromatograficamente puro $\left(5 \% \mathrm{QF}-1,150^{\circ} \mathrm{C}\right)$. $\operatorname{rmp} \delta\left(\mathrm{CCl}_{4}\right): 3,97(4 \mathrm{H}, \mathrm{m}), 2,60(2 \mathrm{H}, \mathrm{q}, \mathrm{J}=8 \mathrm{~Hz})$ sobreposto a $(1 \mathrm{H}, \mathrm{m}), 1,20(3 \mathrm{H}, \mathrm{t}, \mathrm{J}=8 \mathrm{~Hz})$ sobreposto a $1,0-$ $-2,3(8 H, m)$.

I.V. ${ }_{\text {COCOC }}\left(\right.$ filme) $: 1150(1160), 1130,1080,1030 \mathrm{~cm}^{-1}$.

c) Hidrōlise do 6-etiltio-1,4-dioxaspiro $|4,5|$ decano$13,8 \mathrm{~g}(68 \mathrm{mmol})$ do cetal (XLIII), em $100 \mathrm{ml}$ de äcido sulfúrico aquoso $5 \%(\mathrm{v} / \mathrm{v})$, foram aquecidos a refluxo durante cinco horas. A mistura reacional foi extraỉda com éter, o extrato etēreó lavado com uma solução aquosa saturada de bicarbonato de sódio, āgua e, então, seco com sulfato de magnēsio anidro. Apōs evaporar o solvente, submeteu-se o resīduo a destilação à pressão re duzida, obtendo-se $7,8 \mathrm{~g}(72,6 \%)$ da 2-etiltiociclohexanona, p.e. $61-61,8^{\circ} \mathrm{C} / 0,5$ Torr (1it. ${ }^{45} \mathrm{p}$. e. $115^{\circ} \mathrm{C} / 15$ Torr), cromatograficamente pura $\left(5 \%\right.$ QF $\left.-1,150^{\circ} \mathrm{C}\right)$.

$\operatorname{rmp} \delta\left(\mathrm{CCl}_{4}\right): 3,23(1 \mathrm{H}, \mathrm{m}), 2,43(2 \mathrm{H}, \mathrm{q}, \mathrm{J}=7 \mathrm{~Hz})$ e $1,22(3 \mathrm{H}$, $t, J=7 \mathrm{~Hz}$ ) sobrepostos a $1,0-3,1(8 \mathrm{H}, \mathrm{m})$.

I.V. ${ }^{{ }_{\mathrm{CO}}}\left(\mathrm{CCl}_{4}\right): 1707 \mathrm{~cm}^{-1} ;\left(\mathrm{CHCl}_{3}\right): 1701 \mathrm{~cm}^{-1}$.

3.2.3.2. 2-t-Butiltiociclohexanona $(X X X I)^{46}$

a) A reação entre a 2-clorociclohexanona e t-butiltiolato de sōdio, empregando o procedimento de 3.2 .3 .1 a, forneceu o produto desejado em baixo rendimento, juntamente com värios outros produtos (anāilise cromatogräfica, $5 \%$ QF-1, $130^{\circ} \mathrm{C}$ ). 0 pro cedimento descrito a seguir permitiu a obtenção da 2 -t-butiltioci 
clohexanona pura : - A $2,21 \mathrm{~g}$ (96 mmol) de sōdio molecular, em $75 \mathrm{ml}$ de ēter absoluto, foram adicionados, gota a gota, $9,5 \mathrm{~g}$ $(0,105$ mol $)$ de 2-meti1-2-propanotiol, sob agitação e aquecimento. Apōs todo o sōdio ter reagido, adicionaram-se $12,7 \mathrm{~g}$ (96 mmol) de 2-clorociclohexanona em $10 \mathrm{ml}$ de ēter abs., sob agitação e resfriamento a $0^{\circ} \mathrm{C}$. Completada a adição, a mistura reacional foi agitada durante nove horas à temperatura ambiente e, em seguida, jogada em $100 \mathrm{ml}$ de àgua. O extrato etēreo foi separado, lavado com āgua, seco com sulfato de magnēsio anidro e, apōs evaporar o ēter, o produto bruto foi destilado à pressão reduzida. Obtiveram-se $11,4 \mathrm{~g}$ de um 1 íquido de p.e. $80-88^{\circ} \mathrm{C} / 1$ Torr. A anālise cromatogrāfica $\left(5 \%\right.$ QF-1, $\left.130^{\circ} \mathrm{C}\right)$ mostrou tratar-se de uma mistura: $75 \%$ correspondente ao componente principal e os restantes $25 \%$ a outras três substâncias.

\section{b) 6-t-Butiltio-1,4-dioxaspiro $|4,5|$ decano (XLIV)}

Pelo procedimento descrito em $3.2 .3 .1 \mathrm{~b}$, obtiveram-se, a partir de $5,6 \mathrm{~g}$ do produto obtido em $a, 2,0 \mathrm{~g}$ (32 mmol) de etilenoglicol e $50 \mathrm{mg}$ de ācido p-toluenosulfōnico em $15 \mathrm{ml}$ de benzeno abs., $3,7 \mathrm{~g}$ de um lïquido de p.e. $86-88^{\circ} \mathrm{C} / 1$ Torr. A anālise cromatogrāfica $\left(5 \% \mathrm{QF}-1,110^{\circ} \mathrm{C}\right): 91 \%$ de produto principal.

$$
\begin{aligned}
\operatorname{rmp} \delta\left(\mathrm{CCl}_{4}\right): & 3,97(4 \mathrm{H}, \mathrm{m}), 2,50(1 \mathrm{H}, \mathrm{m}), 1,3-2,2(8 \mathrm{H}, \mathrm{m}), \\
& 1,28(9 \mathrm{H}, \mathrm{s}) .
\end{aligned}
$$

I.V. ${ }^{\nu_{\operatorname{COCOC}}}(\mathrm{fi} 1 \mathrm{me}): 1145,1130,1080,1030 \mathrm{~cm}^{-1}$.

c) 2-t-Butiltiociclohexanona (XXXI) - De 3,7g (16 mmol) do cetal (XLIV) e $25 \mathrm{ml}$ de àcido sulfürico aquoso $5 \%$ (v/v), confor me procedimento descrito em 3.2.3.1.e, obteve-se $1,8 \mathrm{~g}(60,2 \%)$ de 2-t-butiltiociclohexanona de p.e. $72-72,5^{\circ} \mathrm{C} / 0,5$ Torr (1it. ${ }^{46}$ p.e. $123-124^{\circ} \mathrm{C} / 16$ Torr $)$, cromatograficamente pura $\left(10 \%\right.$ FFAP, $\left.150^{\circ} \mathrm{C}\right)$. 
68.

$\operatorname{rmp} \delta\left(\mathrm{CCl}_{4}\right): 3,30(1 \mathrm{H}, \mathrm{m}), 2,88(1 \mathrm{H}, \mathrm{m}), 1,4-2,4(7 \mathrm{H}, \mathrm{m})$, 1,40 (s) e 1,30 (s) para um total de $9 \mathrm{H}$.

rmp $\delta\left(\mathrm{CDCl}_{3}\right): 3,45(1 \mathrm{H}, \mathrm{m}), 2,97(1 \mathrm{H}, \mathrm{m}), 1,4-2,5(7 \mathrm{H}, \mathrm{m}) \mathrm{e}$ $1,33(9 H, s)$ de acordo com a literatura ${ }^{46}$.

I.V. $\nu_{\mathrm{CO}}\left(\mathrm{CCl}_{4}\right): 1708 \mathrm{~cm}^{-1} ;\left(\mathrm{CHCl}_{3}\right): 1704 \mathrm{~cm}^{-1}$.

3.2.3.3. 2-Etiltio-2-metilciclohexanona (XXXII)

a) 2-cloro-2-metilciclohexanona ${ }^{64}$ - Partiu-se de $22,4 \mathrm{~g}$ $(0,20 \mathrm{~mol})$ de 2 -metilciclohexanona em $100 \mathrm{ml}$ de tetracloreto de carbono e $29,7 \mathrm{~g}(0,22 \mathrm{~mol})$ de cloreto de sulfurila em $30 \mathrm{ml}$ de tetracloreto de carbono, obtendo-se $18,9 \mathrm{~g}(64,5 \%)$ de 2-cloro-2metilciclohexanona, p.e. $85-87^{\circ} \mathrm{C} / 28$ Torr $\left(1 i t .{ }^{64}\right.$ p.e. $\left.94-96^{\circ} \mathrm{C}\right)$ 27 Torr).

b) 2-Etiltio-2-metilciclohexanona (XXXII) -Empregando-se - procedimento descrito para a 2-etiltiociclohexanona em 3.2.3.1a, obtiveram-se, pela reação de $98,9 \mathrm{~g}(0,129 \mathrm{~mol})$ de 2-cloro-2-metilciclohexanona e de etanotiolato de sódio, preparado a partir de $2,96 \mathrm{~g}(0,129 \mathrm{~mol})$ de sōdio, 8,2g $(0,132 \mathrm{~mol})$ de etanotiol e $100 \mathrm{ml}$ de etanol abs., $15,6 \mathrm{~g}(70,3 \%)$ de produto de p.e. $94-96{ }^{\circ} \mathrm{C} /$ 5 Torr, cromatograficamente puro ( $\left.5 \% \mathrm{QF}-1,110^{\circ} \mathrm{C}\right)$.

Anālise: calculado para $\mathrm{C}_{9} \mathrm{H}_{16}$ OS : C $62,79 \%$ H $9,30 \%$

encontrado : C $62,83 \%$ H $9,75 \%$

$\operatorname{rmp} \delta\left(\mathrm{CCl}_{4}\right): 1,30(3 \mathrm{H}, \mathrm{s}), 1,15(3 \mathrm{H}, t, J=7 \mathrm{~Hz})$ e $1,2-3,2$ $(10 \mathrm{H}, \mathrm{m})$.

I.V. ${ }^{{ }_{\mathrm{CO}}}\left(\mathrm{CCl}_{4}\right): 1703 \mathrm{~cm}^{-1} ;\left(\mathrm{CHCl}_{3}\right): 1695 \mathrm{~cm}^{-1}$. 


\subsubsection{2-Etiltio-4-t-butilciclohexanona (XXXIV)}

a) 4-t-Butilciclohexanona (XLV)65a - Preparou-se o reagente oxidante pela dissolução de $26,8 \mathrm{~g}$ de triōxido de crômio em $50 \mathrm{ml}$ de àgua e $24 \mathrm{ml}$ de ácido sulfūrico conc. Esta solução foi adicionada, sob agitação e temperatura de $30^{\circ} \mathrm{C}$, a uma solução de $31,2 \mathrm{~g}(0,20 \mathrm{~mol})$ de 4-t-butilciclohexanol (mistura dos isômeros cis e trans, Merck-Schuchardt) em $500 \mathrm{ml}$ de acetona. Obtiveram-se $26,3 \mathrm{~g}(85,4 \%)$ de 4 -t-butilciclohexanona de p.f. $46-48,5^{\circ} \mathrm{C}$ (1it. ${ }^{65 a}$ p.f. $\left.48-49^{\circ} \mathrm{C}\right)$.

b) 2-cloro-4-t-butilciclohexanona $(X X X V I)^{48}$ - Em uma sol u ção de $53,4 \mathrm{~g}(0,347 \mathrm{~mol})$ de 4-t-butilciclohexanona, em $70 \mathrm{ml}$ de ācido acético $90 \%$, foram introduzidos, durante duas horas e meia, $26,5 \mathrm{~g}(0,37 \mathrm{~mol})$ de cloro, sob agitação e resfriamento em banho de gelo e àgua. Extraiu-se em ēter, lavou-se o extrato etéreo com solução aquosa saturada de bicarbonato de sōdio atē neutralidade, āgua e solução aquosa saturada de cloreto de sōdio.Apōs secagem com sulfato de magnēsio anidro, evaporou-se o ēter e submeteu-se o produto bruto a uma destilação fracionada, recoThendo-se treze frações: frações 1 a $3,4,5 \mathrm{~g}$, p.e. $26-58^{\circ} \mathrm{C} / 0,2 \mathrm{Torr}$, consistindo principalmente de 4-t-butilciclohexanona ( anālise cromatogräfica, $5 \%$ QF-1, $\left.155^{\circ} \mathrm{C}\right)$; frações 4 a $8,20,1 \mathrm{~g}(30,8 \%)$, p.e. $60-64^{\circ} \mathrm{C} / 0,1-0,3$ Torr ( $1 \mathrm{it} .{ }^{48}$ p.e. $66-67^{\circ} \mathrm{C} / 0,6$ Torr), con sistindo principalmente de trans-2-cloro-4-t-butilciclohexánona (anālise cromatogrāfica, $5 \%$ QF-1, $155^{\circ} \mathrm{C}$ ); fração $9,3,8 \mathrm{~g}$, p.e. $64-69^{\circ} \mathrm{C} / 0,02-0,5$ Torr, mistura de trans-2-cloro-4-t-butilciclohexanona, cis-2-cloro-4-t-butilciclohexanona e uma substância de natureza desconhecida; frações 10 a $13,27,7 \mathrm{~g}$ ( $42,4 \%)$, p.e. $90-102^{\circ} \mathrm{C} / 0,2$ Torr ( $1 \mathrm{it} .{ }^{48}$ p.e. $84-89^{\circ} \mathrm{C} / 0,3-0,5$ Torr), con sistindo principalmente de cis-2-cloro-4-t-butilciclohexanona 
(anālise cromatogräfica, $5 \%$ QF-1, $155^{\circ} \mathrm{C}$ ). Recristalizada vārias vezes de n-pentano, apresentou p.f. $57,5-58,5^{\circ} \mathrm{C}$ (1it. ${ }^{48}$ p.f. $\left.58,5-59,5^{\circ} \mathrm{C}\right)$.

Os espectros de rmp das cis-e trans-2-cloro-4-t-butilciclohexanonas concordam com os da literatura ${ }^{66}$.

C) 2-Etiltio-4-t-butilciclohexanona (XXXIV)

c.l. - Reação de etanotiolato de sódio e trans-2-clo ro-4-t-butilciclohexanona - Pelo procedimento descrito em 3.2.3.1a, obtiveram-se, a partir de 4,04g (2l mmol) de trans-2-cloro-4-tbutilciclohexanona, 0,49g (21 mmol) de sódio, 1,59g (26 mmol) de etanotiol e $25 \mathrm{ml}$ de metanol abs., 4,01g de produto bruto que, pela anālise cromatogrāfica $\left(5 \%\right.$ QF-1, $\left.175^{\circ} \mathrm{C}\right)$ mostrou um pico principal (72\%).

c.2. - Reação de etanotiolato de sōdio e cis-2-cloro4-t-butilciclohexanona - De 8,6g (45 mmol), 1,04g (45 mmol) de sódio, $3,35 \mathrm{~g}$ (54 mmol) de etaṇotiol e $50 \mathrm{ml}$ de metanol abs., ob tiveram-se, empregando o procedimento descrito em $3.2 .3 .1 \mathrm{a}, 8,9 \mathrm{~g}$ de um lỉquido cuja anālise cromatogräfica (5\% QF-1, $\left.175^{\circ} \mathrm{C}\right)$ reve lou um pico principal ( $84 \%$ ) de tempo de retenção igual ao obser vado na anāilise do produto bruto em c.1.

os produtos de c.1. e c.2. foram reunidos e submetidos a destilação à pressão reduzida, obtendo-se $7,2 \mathrm{~g}(50,2 \%$ de um liquido de p.e. $73,4-75^{\circ} \mathrm{C} / 0,045-0,05$ Torr, cromatograficamente puro $\left(5 \% \mathrm{QF}-1,170^{\circ} \mathrm{C}\right)$.

Anālise : calculado para $\mathrm{C}_{12} \mathrm{H}_{22} \mathrm{OS}$ : C $67,29 \%$ H $10,3 \%$

$$
\text { encontrado : C } 67,23 \% \quad \text { H } 10,5 \%
$$

rmp $\delta\left(\mathrm{CCl}_{4}\right): 3,22(1 \mathrm{H}, \mathrm{m}), 2,45(2 \mathrm{H}, \mathrm{q}, \mathrm{J}=7 \mathrm{~Hz})$ e $1,23(3 \mathrm{H}$, t, $J=7 \mathrm{~Hz})$ sobrepostos a $1,0-3,0(7 \mathrm{H}, \mathrm{m}), 0,98$ $(9 H, s)$. 
I.V. ${ }^{{ }_{\mathrm{CO}}}\left(\mathrm{CCl}_{4}\right): 1711 \mathrm{~cm}^{-1} ;\left(\mathrm{CHCl}_{3}\right): 1703 \mathrm{~cm}^{-1}$.

3.2.3.5. Octahidro-4a-metil-3-etiltio-2(1H)-naftalenona (XXXVIII)

a) cis-0ctahidro-4a-meti1-8a-hidroxi-2(1H)-naftalenona (cis-10-meti1-2-decalon-9-01) (XLVI) ${ }^{67}-A 56,0 \mathrm{~g}(0,50 \mathrm{~mol})$ de 2-metilciclohexanona (BDH, redestilada, p.e. $50^{\circ} \mathrm{C} / 10$ Torr) contendo $3 \mathrm{ml}$ de solução $3 \mathrm{~N}$ de etōxido de sōdio em etanol, mantidos a $-10^{\circ} \mathrm{C}$, sob atmosfera de nitrogênio e sob agitação, foram adicionados, durante seis horas, $35,0 \mathrm{~g}(0,50$ mol) de metil vinil cetona (Aldrich, usada sem purificação prēvia). Apōs manter a mistura reacional por mais seis horas a $-10^{\circ} \mathrm{C}$, ela foi transferida a um funil de separação com ajuda de ẻter e uma solução aquosa saturada de cloreto de sōdio. A mistura resultante foi ex traỉda quatro vezes com éter, os extratos etēreos combinados se cos com sulfato de magnēsio anidro e o éter destilado, mantendo-se o volume da solução constante em $700 \mathrm{ml}$, pela adição de n-hexano. Ao se iniciar a cristalização, a solução foi resfriada e, apōs filtração, obtiveram-se $30,0 \mathrm{~g}$ (33\%) de cis-10-metil2-decalon-9-01 de p.f. $119-121^{\circ} \mathrm{C}$ (1it. ${ }^{67}$ p.f. $\left.120-121^{\circ} \mathrm{C}\right)$.

b) $4,4 a, 5,6,7,8$-hexahidro-4a-metil-2(3H)-naftalenona $\left(10\right.$-metil- $1(9)$-octalona-2) $(\text { XLVII })^{67}-30,0 \mathrm{~g}(0,165 \mathrm{~mol})$ de cis10-meti1-2-decalon-9-ol foram misturados com $400 \mathrm{ml}$ de solução aquosa de hidrōxido de potássio a $10 \%$ e destilados com vapor. 0 produto bruto foi submetido a destilação à pressão reduzida,for

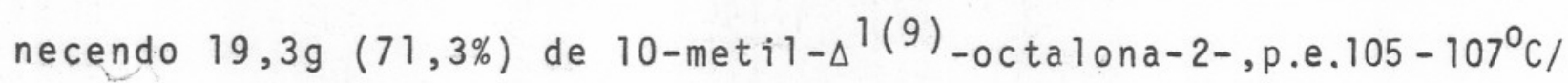
2 Torr (1it. ${ }^{67}$ p.e. $82-83^{\circ} \mathrm{C} / 0,7$ Torr).

c) Trans-octahidro-4a-metil-2(1H)-naftalenona (trans10-metil-2-decalona) (XLVIII) ${ }^{68}$ - Empregou-se o procedimento descri to ${ }^{65 b}$ para a preparação da trans-octahidro-2(1H)-naftalenona. De 
$16,2 \mathrm{~g}(99,4 \mathrm{mmol})$ de (XLVII)dissolvidos em $70 \mathrm{ml}$ de ëter absoluto e aproximadamente $400 \mathrm{ml}$ de amonea liqquida e $3,7 \mathrm{~g}(0,54 \mathrm{~mol})$ de fio de lîtio cortado em pequenos pedaços, obtiveram-se $14,4 \mathrm{~g}$ de produto bruto. Este foi dissolvido em $20 \mathrm{ml}$ de ācido acētico gla cial e foi tratado com uma solução de $4,8 \mathrm{~g}(48,5 \mathrm{mmol})$ de triōxí do de crômio em $3 \mathrm{ml}$ de àgua e $12 \mathrm{ml}$ de ácido acētico glacial. Após uma noite, à temperatura ambiente, a mistura reacional foi aquecida por duas horas em banho-maria. Adicionou-se uma solução de $9,5 \mathrm{~g}$ de hidrōxido de sōdio em $37 \mathrm{ml}$ de água e extraiu-se a mistura continuamente com ēter. O extrato etéreo foi lavado com uma solução aquosa saturada de bicarbonato de potássio, ãgua e solução aquosa saturada de cloreto de sōdio. Após secagem com sulfato de magnésio anidro, o éter foi evaporado e o produto bru to submetido a destilação à pressão reduzida, fornecendo $11,0 \mathrm{~g}$ (67\%) de trans-octahidro-4a-metil-2(1H)-naftalenona de p.e. $82-84^{\circ} \mathrm{C} / 1$ Torr ( $1 \mathrm{it} .{ }^{68} \mathrm{p} . \mathrm{e} .130^{\circ} \mathrm{C} / 20$ Torr). Pela anālise cromatogrāfica $\left(5 \% \mathrm{QF}-1,175^{\circ} \mathrm{C}\right)$, o. produto mostrou conter aproximada mente $10 \%$ de 10 -metil- $\Delta^{1}(9)$-octalona-2. Purificou-se por cromatografia em coluna de sîlica gel (75g) preparada em n-hexano.Co mo eluentes empregaram-se $n$-hexano, $n$-hexano: benzeno $9: 1,8: 2$ e $6: 4$ e finalmente benzeno. A cetona obtida foi redestilada, p.e. $71-72^{\circ} \mathrm{C} / 0,5$ Torr mostrando ser cromatograficamente pura $\left(5 \% \mathrm{QF}-1,175^{\circ} \mathrm{C}\right)$.

d) $3(e)-B r o m o o c t a h i d r o-4 a-m e t i 1-2(1 H)$-naftalenona (trans-3-bromo-trans-10-metil-2-decalona (XXXIX) ${ }^{49}$ - A uma solução de $10,0 \mathrm{~g}(60 \mathrm{mmol})$ de octahidro-4a-metil-2(1H)-naftalenona em $180 \mathrm{ml}$ de àcido acētico glacial contendo 40 gotas de ācido bromîdrico $48 \%$ 65c, adicionaram-se, lentamente e sob agitação, $10,6 \mathrm{~g}$ (66 mmol) de bromo dissolvidos em $60 \mathrm{ml}$ de ácido acētico gla- 
cial. Apōs agitar durante três horas à temperatura ambiente, jọ gou-se a mistura reacional em āgua e extraiu-se a solução aquosa com ēter. O extrato etēreo foi lavado com uma solução aquosa saturada de bicarbonato de sōdio, seco com sulfato de magnēsio anidro e o éter evaporado. O resĩduo foi recristalizado de hexa no-benzeno $(10: 1)$ fornecendo $8,45 \mathrm{~g}(57,2 \%)$ de $3($ e)-bromooctahidro-4a-metil-2(1H)-naftalenona, p.f. $100-105^{\circ} \mathrm{C}$ (1it. ${ }^{49}$ p.f. $\left.101^{\circ} \mathrm{C}\right)$. Uma amostra, apōs vārias recristalizações, forneceu um produto de p.f. $105-107^{\circ} \mathrm{C}$.

$\operatorname{rmp} \delta\left(\mathrm{CCl}_{4}\right): 4,63(1 \mathrm{H}, \mathrm{dd}, \mathrm{J}=13 \mathrm{~Hz}, 7 \mathrm{~Hz}), 1,12(3 \mathrm{H}, \mathrm{s})$ e $1,0-2,5(13 H, m)$.

e) Octahidro-4a-metil-3-etiltio-2(1H)-naftalenona axXVInd A uma solução de etanotiolato de sódio obtida de $0,70 \mathrm{~g}$ ( $30 \mathrm{mmol}$ ) de sōdio, 2,06g (33 mmol) de etanotiol e $17 \mathrm{ml}$ de metanol absoluto, adicionaram-se gota a gota, sob agitação e resfriamento a $-10^{\circ} \mathrm{C}, 7,4 \mathrm{~g}(30 \mathrm{mmol})$ de $3(\mathrm{e})$-bromooctahidro-4a-metil-2(1H)-naf talenona dissolvida em $25 \mathrm{ml}$ de THF. Após voltar à temperatura ambiente, a mistura reacional foi jogada em āgua e o óleo forma do extraīdo com ēter. O extrato etéreo foi lavado com água, solução aquosa saturada de cloreto de sōdio e seco com sulfato de magnēsio anidro. 0 produto bruto submetido a destilação à pressão reduzida forneceu $4,08 \mathrm{~g}(60 \%)$ de um 1 ỉquido de p.e. $83-84^{\circ} \mathrm{C} /$ 0,03 Torr, cujo espectro de rmp estava de acordo com a estrutura da octahidro-4a-metil-3-etiltio-2(1H)-naftalenona. 0 produto foi redestilado (p.e. $108^{\circ} \mathrm{C} / 0,2$ Torr) e mostrou-se cromatografi camente puro $\left(5 \% \mathrm{QF}-1,175^{\circ} \mathrm{C}\right)$. 
$\operatorname{rmp} \delta\left(\mathrm{CCl}_{4}\right): 3,45(0,6 \mathrm{H}, \mathrm{dd}, \mathrm{J}=12 \mathrm{~Hz}, 6 \mathrm{~Hz})$ e $3,16(0,4 \mathrm{H}, \mathrm{m})$, $2,47(q, J=7 \mathrm{~Hz})$ e $2,39(q, J=7 \mathrm{~Hz})$ total $2 \mathrm{H}$, $1,17(3 \mathrm{H}, t, J=7 \mathrm{~Hz}), 1,11$ (s) e 1,05 (s) total $3 \mathrm{H}$, sobrepostos a $1,0-2,2(13 \mathrm{H}, \mathrm{m})$.

$r m^{13} \mathrm{C} \delta\left(\mathrm{CCl}_{4}\right)$, referēncia TMS : 202,9 e $203,3 \quad(\mathrm{C}=0)$.

I.V. ${ }^{-} v_{\mathrm{CO}}\left(\mathrm{CCl}_{4}\right): 1723$ e $1705 \mathrm{~cm}^{-1} ;\left(\mathrm{CHCl}_{3}\right): 1713(1703) \mathrm{cm}^{-1}$.

3.2.3.6. Reações de sulfenilação de cetonas ${ }^{44}$

a) Solventes e reagentes - A hexametiltrifosforamida (HMPA) (Aldrich) foi destilada de hidreto de cálcio; a isopropilciclohexilamina (ICA) (Aldrich) foi destilada de hidroxido de potāssio e o tetrahidrofurano (THF) (Aldrich) de hidreto de litio e aluminio, imediatamente antes do uso. O HMPA e a ICA fo ram mantidos sobre peneiras moleculares em frascos munidos de septos. Empregou-se uma solução 2,0M de n-butillītio (Ventron, Alfa Products).

0 dissulfeto de dimetila foi preparado da seguinte má neira ${ }^{69}: 250 \mathrm{~g}(1,76 \mathrm{~mol})$ de iodeto de metila, $500 \mathrm{~g}(2,02 \mathrm{~mol})$ de tiossulfato de södio pentahidratado em $400 \mathrm{ml}$ de metanol e $500 \mathrm{ml}$ de àgua foram aquecidos a refluxo sob agitação durante très horas. Destilaram-se aproximadamente $250 \mathrm{ml}$ de metanol, adicionaram-se, lentamente, $245 \mathrm{~g}(4,37 \mathrm{~mol})$ de hidrōxido de potāssio em $500 \mathrm{ml}$ de àgua e aqueceu-se por mais uma hora a refluxo. A mistura reacional foi diluĩda com āgua, extraỉda com ēter, o extra to etēreo lavado com āgua e seco com sulfato de magnēsio anidro. Destilou-se o ēter e, em seguida, o produto, obtendo-se $44,4 \mathrm{~g}$ $(53,8 \%)$ de dissulfeto de dimetila de p.e. $106-107^{\circ} \mathrm{C}$ (1it. ${ }^{69} \mathrm{p} . \mathrm{e}$. $\left.110^{\circ} \mathrm{C}\right)$. 0 dissulfeto foi redestilado de hidreto de cālcio e man tido sobre peneiras moleculares em frasco munido de septo. 
b) Procedimento geral - A aparelhagem usada foi seca passando-se uma corrente de nitrogênio seco pela mesma e aquecendo-a com chama fuliginosa. Adicionou-se 1 equivalente de n-butil-1ĩtio a uma solução de 1 equivalente de ICA em THF a $-78^{\circ} \mathrm{C}$. Completada a adição, elevou-se a temperatura da mistura reacional a $-25^{\circ} \mathrm{C}$ e, após trinta minutos, adicionou-se, lentamente, a cetona dissolvida em THF/HMPA. Agitou-se por trinta mi nutos a $-25^{\circ} \mathrm{C}$ e, apōs atingir a temperatura ambiente, a mistura foi mantida sob agitação por quarenta minutos. Resfriou-se a $0^{\circ} \mathrm{C}$, adicionou-se o dissulfeto de dimetila e agitou-se por uma hora à temperatura ambiente. A mistura reacional foi jogada em ēter e ācido clorídrico 10\%. O extrato etēreo foi lavado com ác do clorỉdrico 10\%, solução aquosa saturada de bicarbonato de sō dio, āgua, solução aquosa saturada de cloreto de sōdio e seco com sulfato de magnésio anidro. Apōs evaporar o ēter, o produto bruto foi cromatografado em coluna de sîlica gel preparada em n-hexano.

3.2.3.7. 2-Metiltiociclohexanona $(X X I X)^{44}$ - Preparou-se o amideto (67 mmol) em $57 \mathrm{ml}$ de THF. Após trinta minutos a $-25^{\circ} \mathrm{C}$ adiciona ram-se $3,0 \mathrm{~g}(30,6$ mmol) de ciclohexanona em $7,5 \mathrm{ml}$ de THF e $30 \mathrm{ml}$ de HMPA. Depois de agitar a mistura reacional durante qua renta minutos à temperatura ambiente, resfriou-se a $0^{\circ} \mathrm{C}$ e adicionaram-se $6,37 \mathrm{~g}(67,8 \mathrm{mmol})$ de dissulfeto de dimetila. Após procedimento usual $(3.2 .3 .6 .6)$ obtiveram-se 4,83 de produto cuja anālise cromatogrāfica $\left(5 \% \mathrm{QF}-1,120^{\circ} \mathrm{C}\right)$ mostrou um pico prin cipal $(75,4 \%)$ correspondente à 2-metiltiociclohexanona.

Cromatografou-se o produto bruto em coluna de sỉlica gel $(90 \mathrm{~g})$ usando como eluente benzeno absoluto. Obteve-se $1,87 \mathrm{~g}$ $(42,2 \%)$ de 2 -metiltiociclohexanona cromatograficamente pura ( $5 \%$ $\left.\mathrm{QF}-1,120^{\circ} \mathrm{C}\right)$. 
rmp $\delta\left(\mathrm{CDCl}_{3}\right): 3,25(1 \mathrm{H}, \mathrm{m}), 2,07$ (3H, s) sobreposto a $1,0-2,8$ $(8 H, m)$.

I.V. $\nu_{\mathrm{CO}}\left(\mathrm{CCl}_{4}\right): 1709 \mathrm{~cm}^{-1} ;\left(\mathrm{CHCl}_{3}\right): 1701 \mathrm{~cm}^{-1}$.

3.2.3.8. 2-Metiltio-4-t-butilciclohexanona(XXXIII) - De acordo com - procedimento geral das sulfenilações (3.2.3.6.b), obtiveram-se, de $3,23 \mathrm{~g}$ (21 mmol) de 4-t-butilciclohexanona em $5 \mathrm{ml}$ de THF e $28,5 \mathrm{ml}$ de HMPA, 6,42g $(44,6 \mathrm{mmol})$ de ICA em $38 \mathrm{ml}$ de THF e 4,25g $(4,52 \mathrm{mmol})$ de dissulfeto de dimetila, 4,28g de um lỉquido cuja anālise cromatogräfica $\left(5 \%\right.$ QF- $\left.1,160^{\circ} \mathrm{C}\right)$ mostrou um pico principal $(83 \%)$. O produto foi cromatografado em coluna de silitica gel $(90 \mathrm{~g})$ empregando benzeno absoluto como eluente. Isolaram-se.2,91g $(69,4 \%)$ de um 1 îquido cromatograficamente puro $\left(5 \%\right.$ QF-1, $\left.160^{\circ} \mathrm{C}\right)$. Submetido a destilação à pressão reduzida, p.e. observado : $85-87^{\circ} \mathrm{C} / 1$ Torr.

Anālise: calculado para $\mathrm{C}_{11} \mathrm{H}_{20} \mathrm{OS}$ : C $66,0 \%$ H $10,0 \%$

$$
\text { encontrado : C } 66,05 \% \text { H } 10,16 \%
$$

$\operatorname{rmp} \delta\left(\mathrm{CCl}_{4}\right): 3,0(1 \mathrm{H}, \mathrm{m})$ sobreposto a $(0,5 \mathrm{H}, \mathrm{m}), 1,96(3 \mathrm{H}, \mathrm{s})$ sobreposto a $1,2-3,0(6,5 \mathrm{H}, \mathrm{m}), 0,90(9 \mathrm{H}, \mathrm{s})$.

I.V. $\nu_{\mathrm{CO}}\left(\mathrm{CCl}_{4}\right): 1711 \mathrm{~cm}^{-1} ;\left(\mathrm{CHCl}_{3}\right): 1704 \mathrm{~cm}^{-1}$.

3.2.3.9. 0ctahidro-4a-metil-3-metiltio-2(1H)-naftalenona (XXXVII) ${ }^{44}$

0 amideto ( 38,9 mmol) foi preparado pela maneira usual $(3.2 .3 .6 b$ ) em $28 \mathrm{ml}$ de THF a $-25^{\circ} \mathrm{C}$. Depois de trinta minutos adicionou-se uma solução de $3,07 \mathrm{~g}(18,5$ mmol) de octahidro-4a-metil-2(1H)naftalenona em $4 \mathrm{ml}$ de THF e $24 \mathrm{ml}$ de HMPA. Após agitar trinta minutos a $-25^{\circ} \mathrm{C}$, quarenta minutos à temperatura ambiente, resfriou-se a $0^{\circ} \mathrm{C}$ e adicionaram-se $3,66 \mathrm{~g}(38,9 \mathrm{mmol})$ de dissulfeto 
de dimetila. Obtiveram-se $3,89 \mathrm{~g}$ de produto bruto cuja anālise cromatogräfica $\left(5 \%\right.$ QF-1, $\left.180^{\circ} \mathrm{C}\right)$ mostrou um pico principal $(73 \%)$. Cromatografou-se em coluna de silica gel ( $90 \mathrm{~g}$ ) empregando como eluente benzeno absoluto e isolou-se $1,75 \mathrm{~g}(44,7 \%)$ de octahidro-4a-metil-3-metiltio-2(1H)-naftalenona cromatograficamente pura $\left(5 \%\right.$ Q $\left.-1,180^{\circ} \mathrm{C}\right)$.

rmp $\delta\left(\mathrm{CDCl}_{3}\right): 3,49(0,7 \mathrm{H}, \mathrm{dd}, \mathrm{J}=12 \mathrm{~Hz}, 6 \mathrm{~Hz})$ e $3,07(0,3 \mathrm{H}, \mathrm{m})$, 2,06 (s) e 2,02 (s) total $3 \mathrm{H}$ e 1,13 (s) e 1,09 (s) total $3 \mathrm{H}$ sobrepostos a $1,0-2,4(13 \mathrm{H}, \mathrm{m})$. I.V. ${ }^{{ }_{\mathrm{CO}}}\left(\mathrm{CCl}_{4}\right): 1723$ e $1705 \mathrm{~cm}^{-1} ;\left(\mathrm{CHCl}_{3}\right): 1713$ (1703) $\mathrm{cm}^{-1}$.

\subsubsection{3-Metiltio-1,7,7-trimetilbiciclo|2.2.1 heptanona-2} (3-metiltiocânfora)(XLII) - 0 isopropilciclohexilamideto (90,8 mmol) em $76 \mathrm{ml}$ de THF foi obtido pela maneira usual (3.2.3.6.b). Adicionaram-se $6,39 \mathrm{~g}(42 \mathrm{mmol})$ de $(+)-1,7,7$-trimetilbiciclo|2.2.1| heptanona-2 $2^{*}$ em $10 \mathrm{ml}$ de THF e $57 \mathrm{ml}$ de HMPA a $-25^{\circ} \mathrm{C}$. A mistura reacional assim obtida, apōs agitação durante quarenta minutos à temperatura ambiente, foram adicionados $8,50 \mathrm{~g}(90,4 \mathrm{mmol}) \mathrm{de}$ dissulfeto de dimetila a $0^{\circ} \mathrm{C}$. Apōs procedimento normal, isolaram-se $8,35 \mathrm{~g}$ de um $1 \bar{i} q u i d o$ cuja anālise cromatogrāfica ( $5 \%$ QF-1, $160^{\circ} \mathrm{C}$ ) mostrou dois picos principais, um correspondente à cânfo ra $(32 \%)$ e outro ao produto esperado (60\%).

Dividiu-se o līquido obtido em duas partes e cromato grafou-se em coluna de sîlica gel ( $90 \mathrm{~g})$, usando benzeno absoluto como eluente. Obtiveram-se $3,32 \mathrm{~g}(39,9 \%)$ de um lĩquido croma tograficamente puro $\left(5 \% \mathrm{QF}-1,150^{\circ} \mathrm{C}\right)$ de p.e. $83-84^{\circ} \mathrm{C} / 1$ Torr.

${ }^{*}(+)$-Cânfora, p.f. $176-178^{\circ} \mathrm{C}, \mathrm{Aldrich}$, gentilmente cedida pelo Dr. Timothy Brocksom. 
78.

$$
\begin{aligned}
& \text { Anālise : calculado para } \mathrm{C}_{11} \mathrm{H}_{18} \mathrm{OS} \text { : C } 66,67 \% \mathrm{H} 9,09 \% \\
& \text { encontrado : C } 66,61 \% \text { H } 9,39 \% \\
& \operatorname{rmp} \delta\left(\mathrm{CCl}_{4}\right): 3,09(1 \mathrm{H}, \mathrm{d}, \mathrm{J}=5 \mathrm{~Hz}), 2,22(3 \mathrm{H}, \mathrm{s}), 0,98(3 \mathrm{H}, \mathrm{s}) \text {, } \\
& 0,86(3 \mathrm{H}, \mathrm{s}), 0,84(3 \mathrm{H}, \mathrm{s}) \text { e } 1,16-2,4(5 \mathrm{H}, \mathrm{m}) \text {. } \\
& \text { I.V. } \nu_{\mathrm{CO}}\left(\mathrm{CCl}_{4}\right): 1746 \mathrm{~cm}^{-1} ;\left(\mathrm{CHCl}_{3}\right): 1739 \mathrm{~cm}^{-1} \text {. }
\end{aligned}
$$


SUMARR IO

No presente trabalho são apresentados os espectros de absorção no ultravioleta, em n-hexano e metanol absolutos, das 2-mercapto-(XLI) e 2-etiltiociclopentanonas (XL), 2-metiltio- $(X X X I X), 2$-etiltio- $(X X X), 2$-t-butiltio-(XXXI) e 2-etiltio-2-metilciclohexanonas (XXXII). A fim de melhor compreender a importāncia das conformações moleculares nas modificações observadas nas bandas de absorção correspondentes às transições $n \rightarrow \pi^{*}$ do grupo carbonila e $n \rightarrow \sigma^{*}$ do àtomo de enxofre, foram sintetizadas vārias cetonas a-alquiltio-substituídas conformacionalmente definidas: 2-metiltio-(XXXIII) e 2-etiltio-4-t-butilciclohexanonas (XXXIV), os 3-metiltio-(XXXVII) e 3-etiltio(XXXVIII) derivados da trans-octahidro-4a-metil-2(1H)-naftaleno na e a 3-metiltio-1,7,7-trimetil-biciclo[2.2.1] heptanona-2(XLII). As propriedades espectroscōpicas dos compostos estudados são discutidas considerando as possiveis interações eletrōnicas entre o ātomo de enxofre e o grupo carbonila. Conclui-se que as interações dependem das conformações moleculares e que serão maiores quando: (a) - A ligação C-S ocupar uma posição axial ou quasi-axial; (b) - A conformação do grupo alquiltio permitir a māxima superposição do par solitārio de elétrons do enxofre com a ligação $C_{C=0}-C_{\alpha}$. 
The ultraviolet absorption spectra in absolute n-hexane and methanol of 2-mercapto-(XLI) and 2-ethylthiocyclopentanones $(X L)$, 2-methylthio-(XXIX), 2-ethylthio- $(X X X)$, 2-t-butylthio-(XXXI) and 2-ethylthio-2-methylcyclohexanones (XXXII) are presented. In order to evaluate the importance of the molecular conformations upon the observed modifications of the absorption bands due to the $n \rightarrow \pi^{*}$ transition of the carbonyl group and $n \rightarrow \sigma^{*}$ transition of the sulphur atom, several conformationally defined $\alpha$-alkylthio-ketones were synthesized: 2-methylthio-(XXXIII) and 2-ethylthio-4-t-butylcyclohexanones (XXXIV), the 3-methylthio-(XXXVII) and 3-ethylthio (XXXVIII) derivatives of trans-octahydro-4a-methyl-2(1H)naphtalenone and 3-methylthio-1,7,7-trimethyl-bicyclo [2.2.1] heptan-2-one (XLII).

The spectroscopic properties of the studied compounds are discussed, considering the possible orbital interactions between the sulphur atom and the carbonyl group. It is concluded that such interactions are conformation dependent and are more important when: (a) - The C-S bond is axial or quasi-axial; (b) - The conformation of the alkylthio group allows the maximum overlap of the sulphur lone-pair and the $C_{C=0}-C_{\alpha}$ bond. 


\section{REFERENCIAS BIBLIOGRĀF ICAS}

1. A. Burawoy, J.Chem.Soc., 1929, 1177.

2. H.L.McMurry, J.Chem.Phys., 1941, 9, 231.

3. M. Kasha, Discuss.Faraday Soc., 1950, 9, 14.

4. J.N.Murre11, "The Theory of the Electronic Spectra of Organic Molecules", Chapman \& Hall, 1971 , pag. 158 e seg.

5. H.Jaffé e M.Orchin, "Theory and Applications of Ultraviolet Spectroscopy", John Wiley \& Sons, Inc., 1970 (a)pag. 105; (b) pag. 181 .

6. J.S.Lake e A.J.Harrison, J.Chem.Phys., 1959, 30, 361.

7. (a) N.S.Bayliss e G.Wills-Johnson, Spectrochim.Acta, 1968, 24A, 551; (b) ibid, 1968, 24A, 563.

8. H.McCone11, J.Chem.Phys., 1952, 20, 700.

9. G.C.Pimente1, J.Am.Chem.Soc., 1957, 79, 3323.

10. (a) E.M.Kosower e G.S.Wu, J.Am.Chem.Soc., 1961, 83, 3142;

(b) E.M.Kosower, G.S.Wu e T.S.Sorensen, ibid, 3147.

11. C.Trufem Filho, "Tese de Doutoramento", Instituto de Quimica da Universidade de São Paulo, 1976, capítulo I.

12. H.Eyring, J.Walter e G.E.Kimbal1, "Quantum Chemistry", John Wiley \& Sons, Inc., 1967, pag. 342.

13. C.Djerassi, "Optical Rotatory Disperson, Applications to Organic Chemistry", McGraw-Hill Book Comp., 1960, (a) capitulo 12; (b) capítulo 13.

14. W.Moffitt, R.B.Woodward, A.Moscowitz, W.Klyne e C.Djerassi, J.Am.Chem.Soc., 1961, 83, 4013. 
15. T.D.Bouman e D.A.Lightner, J.Am.Chem.Soc., 1976, 98, 3145 e referências citadas.

16. R.C.Cookson, J.Chem.Soc., 1954, 282.

17. N.J.Leonard e F.H.Owens, J.Am.Chem.Soc., 1958, 80, 6039.

18. N.L.Allinger, J.C.Tai e M.A.Miller, J.Am.Chem.Soc., 1966, $\underline{88}, 4495$.

19. L.Labhart e G.Wagniēre, Helv.Chim.Acta, 1959, 42, 2219.

20. R.C.Cookson, J.Henstock e J.Hudec, J.Am.Chem.Soc., 1966 , 88,1060 .

21. J.Hudec, J.C.S.Chem.Comm., 1970, 829.

22. R. Hoffmann, Accounts Chem.Res., 1971, 4 , 1 e referências c $\underline{j}$ tadas.

23. C.Levin, R.Hoffmann, W.J.Hehre e J.Hudec, J.C.S.Perkin II, $1973,210$.

24. A.W.J.D.Deckers, J.W.Verhaeven e W.N.Speckamp, Tetrahedron, $1973, \underline{29}, 1691$.

25. C.Worre11, J.W.Verhoeven e W.M.Speckamp, Tetrahedron, 1974 , 30, 3525 .

26. E.E.Ernstbrunner e J.Hudec, J.Am.Chem.Soc., 1974, 96, 7106.

27. J.Hudec, J.C.S.Perkin II, 1975, 1020.

28. L.Libit e R.Hoffmann, J.Am.Chem.Soc., 1974, 96, 1370.

29. P.Pasman, J.W.Verhoeven e T.J.de Boer, Tetrahedron, 1976 , 32, 2827 .

30. E.A.Fehnel e M.Carmack, J.Am.Chem.Soc., 1949, 71, 84.

31. N.J.Leonard, T.W.Milligan e T.L.Brown, J.Am.Chem.Soc., 1960, 82, 4075 . 
32. G.Bergson e A.L.Delin, Arkiv Kemi, 1962, 18, 489.

33. L.A.Paquette e L.D.Wise, J.Am.Chem.Soc., $1967,89,6659$.

34. R.Herzschuh e R.Borsdorf, J.Electroanal.Chem., 1969, 23, 55 .

35. B.Wladislaw, R.Rittner e H.Viertler, J.Chem.Soc.(B), 1971 , 1859 .

36. B.Wladislaw, H.Viertler, F.A.C.Andrade e E.Berthold Demant, Int.J.Sulfur Chem., 1972, 2A, 161.

37. G.Snatzke e B.Wolfram, Tetrahedron, 1972, 28, 655.

38. M.M.Cook e C.Djerassi, J.Am.Chem.Soc., 1973, 95, 3678.

39. B.T.Buzzi, P.R.01ivato, R.Rittner, C.Trufem, H.Viertler e B.Wladislaw, J.C.S.Perkin II, $1975,1294$.

40. P.R.01ivato, H.Viertler, B.Wladislaw, K.C.Cole e C.Sandorfy, Can.J.Chem., 1976, 54, 3026.

41. K.C.Cole, C.Sandorfy, M.T.Fabi, P.R.01ivato, R.Rittner, C. Trufem, H.Viertler e B.Wladislaw, J.C.S.Perkin II, 1977, 2025 .

42. P.R.01ivato, H.Viertler, B.Wladislaw, P.Sauvageau e C. Sandorfy, 1978, manuscrito submetido à publicação.

43. Yuh-Hsu Pan e J.B.Stothers, Can.J.Chem., 1967, 45, 2943 e referências citadas.

44. B.M.Trost, T.N.Salzmann e K.Hiroi, J.Am.Chem.Soc., 1976 , $\underline{98}, 4887$.

45. M.Mousseron, J.Jacquier e A.Fontaine, Bull.Soc.chim.France, $1952,767$.

46. W.C.Lumma, Jr. e G.A.Berchtold, J.Org.Chem., 1969, 34, 1566. 
47. E.L.Eliel, N.L.Allinger, S.J.Angyal e G.A.Morrison, "Conformational Analysis", Interscience Publ., Inc., 1965 (a) 44 ; (b) 48 .

48. N.L.Allinger, J.Allinger, L.A.Freiberg, R.F.Czaja e N.A. LeBe1, J.Am.Chem.Soc., 1960, 82, 5876.

49. A.Casadeva11, E.Casadevall e M.Lasperas, Bull.Soc.chim. France, $1968,4506$.

50. M.Lasperas, A.Casadeval1 e E.Casadeva11, Bu11.Soc.Chim. France, $1971,3209$.

51. F.V.Brutcher, Jr., T.Roberts, S.J.Barr e N.Pearson, J.Am. Chem.Soc., 1959, 81, 4915.

52. I.C.Coelho Calegão, "Tese de Doutoramento", Instituto de Quỉmica da Universidade de São Paulo (em elaboração).

53. B.Wladislaw, P.R.01ivato e R.Rittner, Rev.Latinoamer.Quim., $1974, \underline{5}, 206$.

54. W.D.Kumler, J.N.Shoolery e F.V.Brutcher, Jr., J.Am.Chem.Soc., $1958,80,2533$.

55. F.A.L.Anet, Can.J.Chem., 1961, 39, 789.

56. P.G.Gassman, D.P.Gilbert e S.M.Cole, J.Org.Chem., $1977, \underline{42}$, 3233.

57. A.Padwa e A.Battisti, J.Am.Chem.Soc., 1972, 94, 521.

58.' C.Ganter e J.F.Moser, Helv.Chim.Acta, 1969, 52, 725.

59. C.H.Robinson, L.Milewich, G.Snatzke, W.Klyne e S.R.Wallis, J.Chem.Soc. (C), 1968, 1245.

60. J.S.Rosenfield e A.Moscowitz, J.Am.Chem.Soc., 1972, 94 , 4797. 
61. D.D.Perrin, W.L.F.Armarego e D.R.Perrin, "Purification of Laboratory Chemicals", Pergamon, 1966.

62. M.Kuhn, J.prakt.Chemie, 1940, 156, 103.

63. A.I.Voge1, "A Textbook of Practical Organic Chemistry", 3. ed., Longmans, 1970, pag. 429.

64. E.W.Warnhoff, D.G.Martin e W.S.Johnson, Org. Synth., Coll. Vol. IV, John Wiley \& Sons, Inc., 1963, pag. 162.

65. R.S.Monson, "Advanced Organic Synthesis", Academic Press, Inc., 1972, (a) pag. 3;(b) pag.27; (c) pag. 50.

66. J.Cantacuzène, J.Petrissans e Dang-Quoc-Quan, Tetrahedron Letters, $1967,2543$.

67. J.A.Marsha11 e W.I.Fanta, J.Org.Chem., 1964, 29, 2501.

68. M.Yanagita, K.Yamakawa, A.Tahara e H.Ogura, J.Org.Chem., $1955,20,1767$.

69. S.Blackburn e F.Challenger, J.Chem.Soc., 1938, 1872. 